\title{
Economic Competition for High Profits from Antarctic Living Resources in Their Protection Area
}

\author{
Ryszard Jacek Traczyk \\ Department of Oceanography and Geography, University of Gdańsk, Gdynia 81378, Poland
}

\begin{abstract}
Since 1790, Antarctic living resources were becoming subjects of competition among the exploiters to be first in obtaining the maximum profit from them. This led to subsequent extinction of valuable species from fur seals and next penguins, large through small whales, industrial demersal fish, further to pelagic species and now toothfish, crabs and krill. Catch proportions of their numerous and biomass decrease. The biomass of South Georgia Icefish estimated for 40 years in spide of decreasing trend has one of the largest components - the oscillations with periods of 3 years or 4 years. Their models explain large biomass fluctuations in the years 1975 to 1981 with amplitudes $\pm 15 \times 10^{3}$ tonnes around average $20 \times 10^{3}$ tonnes and further decline up to 2005 season with oscillation $\pm 4 \times 10^{3}$ tonnes around average $5 \times 10^{3}$ tonnes. For future season, 2016 model predicts a little increase of the biomass oscillation at level of $8 \times 10^{3}$ tonnes with reduced amplitude $2 \times 10^{3}$ tonnes. Slowly increase density of adult fish was also reported for target similar and close related mackerel icefish. Additional references for biomass levels help reduce the risk of further depletion biomass of Pseudochaenichthys georgianus which already declined to 75\%. As global warming promote phytoplankton growth, replacing krill fishery by algae farms can save unique Antarctic heritages.
\end{abstract}

Key words: Maximum profits from resources, fish biomass, age of icefish, Antarctic fish, krill.

\section{Introduction}

In the Antarctic, first human settlements are whales stations that eliminated long transport to competitions area for whales. After prohibition on whales, they were rearranged into research stations to constitute the national law across science interest for Antarctic exploration. Twenty eight countries have 82 research stations that along human existence produce waste, which contaminate Antarctic shores, hatcheries for icefish. Sewage disposal and pollution from research stations, tourist visits and other activities are carried out according to the instructions of the team of experts of the Scientific Committee on Antarctic Research (SCAR) for the matters of waste disposal, who has to keep her virginity as recommended by the Antarctic treaty of 1985 [1]. But the disposal and treatment of the wastes generated by people in polar settlements have lacked optimal solutions. Untreated sewage

Corresponding author: Ryszard Jacek Traczyk, master, main research field: biological oceanography. dumping to the sea (permitted under the code of conduct recommended by SCAR) were still practiced and have to be more rigorous since there are even drinking water need to be chosen with great care and so to safe larvae [2].

The Antarctic waters are the most sterile in the World's Ocean, because of Antarctic Circumpolar Current, which isolate it from the rest of world (Fig. 1). There is scarcity of biodegrading organisms and waste removal is slow or nearly nonexistent [2]. Because of that, Antarctica is vulnerable for wastes continuously produced from human settlement: whenever discharge occurred a spread of contaminated water, along the shore and into tidal cracks was inevitable and generate deadly condition for inshore developing icefish larvae [2]. Sixty-six percent of fish exposed to sewage were death [2].

Although there are reports on plastic water pollution and air locally by lead and mercury, including those related to increased emissions in the southern Hemisphere, the content of mercury in water, sediment, 


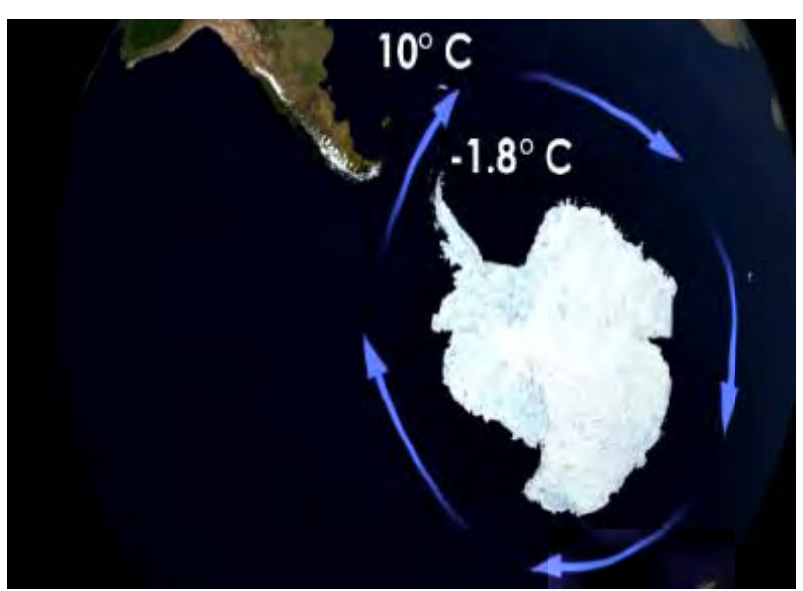

Fig. 1 The isolation creates the world's largest current of the West Wind Drift, which from 25 million years ago orbits consistently around Antarctica when it lost the connection with south America and moved up to the pole.

phytoplankton, macroalgae, krill and several bottom invertebrates does not show an increased accumulation in the Antarctic ocean food ladder [3-5].

Therefore, the consumption of fish and other Antarctic fruits is not dangerous by mercury poisoning, but conversely by displacing or competing with food coming from high polluted oceans. For this advantage in exploitation of living Antarctic resources, the largest participation have countries with a high consumption of fish and very high demand, that drive their fishery from nearest contaminated stock to Antarctic far away but offering clean resources.

The Antarctic living resources (in Atlantic sector mainly from shelf of South Georgia Island, Fig. 2) can exploit states that are Members (25) or Accedes (11) of the Convention on the Conservation of Antarctic Marine Resources (CCAMLR). In past, the Antarctic fisheries lead to extinction valuable species in competition for high profit: fur seals in 1825, whales and overexploitation of finfish. Across to that, fisheries are now managed to balance conservation and rational use of living resources, which can maintain existing ecological relationship. They were required to use catch limits to ensure the long term sustainability of the fishery, catch only a certain amount, allowing the rest in the sea to rebirth in spite of natural mortality (due to being eaten by whales, seals, penguins, birds and unreported catches). Fishing limits are calculated by Scientific Committee CCAMLR in Hobart, fixing high for those resources if they had indicated a good state of biomass. Fish biomass is the subject of study of Working Group of Fish Stock Assessment (WGFSA) and all Antarctic fisheries [6]. The target species of fish at South Georgia Island was the mackerel icefish, which usually represented about 43\% of the catch in 1988 . But now constitute only $1 \%$. Much worst is with South Georgia Icefish. In the contrary, a toothfish are numerous in the catches and now is target species for fishery. Adult toothfish live in deeper waters. Changing the structure of fish fauna may indicate a change in the ecological status of the basin. Obtaining a high biomass of some fish (large peaks in catches of mackerel icefish in the mid 1970s and 1980s) and decline in others (overexploitation of marbled rockcod, Notothenia rossii) indicate that the relative ecological balance in the study area and the lack of proper fisheries, change of environment or the large fluctuation and creating super aggregations are in a range of species appearances [7, 8]. There are no answer, why icefish were not recovered in spite of many years protections and reduction of catches on sustainable level. Their biomass should be maintained by reducing fishery in a half [6]. One of the objectives of this work is to present the trends in changes of biomass of South Georgia Icefish and in its dominance relations. Additional reference for biomass levels is a valuable for reduce the risk of depletion when biomass levels are estimated to be very low, as it is for Pseudochaenichthys georgianus with $75 \%$ declined for its biomass $[9,10]$.

\section{Material and Methods}

Samples of Pseudochaenichthys georgianus were collected during summer's cruises (Dec.-Feb.) in the Antarctic Peninsula 1978-2009 and the South Georgia Island area since 1976 up to 1991 (Figs. 2-4). 


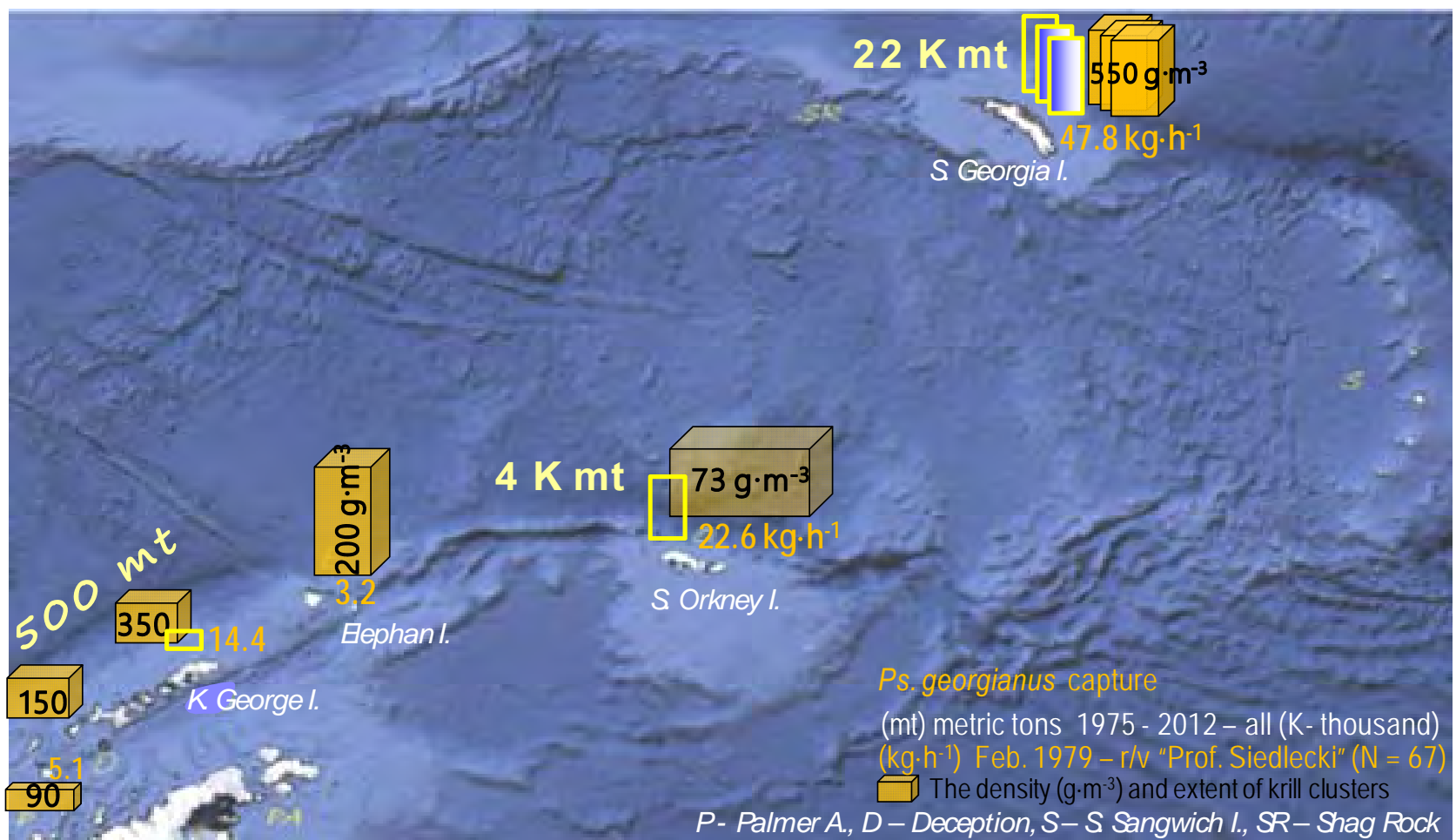

Fig. 2 Catch of Pseudochaenichthys georgianus and Euphausia superba in the Atlantic sector of the Antarctic ocean during the expedition on $\mathbf{r} / \mathbf{v}$ "Prof. Siedlecki" in 1978-1979, the largest density and biomass of krill at the South Georgia Island = 1,502 tons, there caught most fish as well, scotia arc of islands and underwater ridges: the remain from the continent connection.

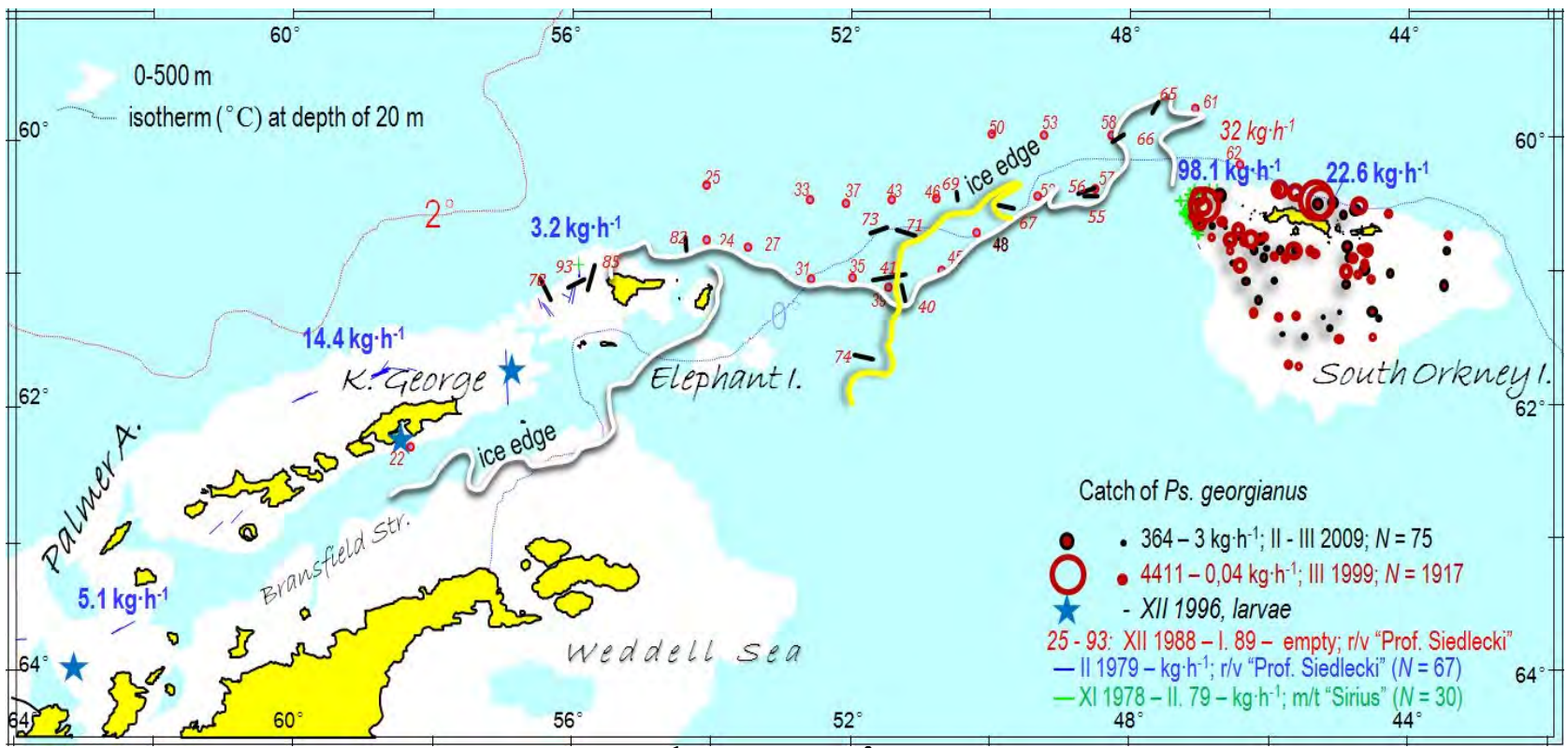

Fig. 3 Places, the catches or biomass density $\left(\mathrm{kg}^{-1} \mathrm{~h}^{-1}=8.82 \cdot \mathrm{kg} \cdot \mathrm{km}^{-2}\right)$ of Pseudochaenichthys georgianus on the shelf South Shetland Island, in summers 1978, 1979, 1999 and 2009, places of sample of Euphausia superba in ice edge zone between Elephan Island and South Orkney Island in summers 1988/1989. 


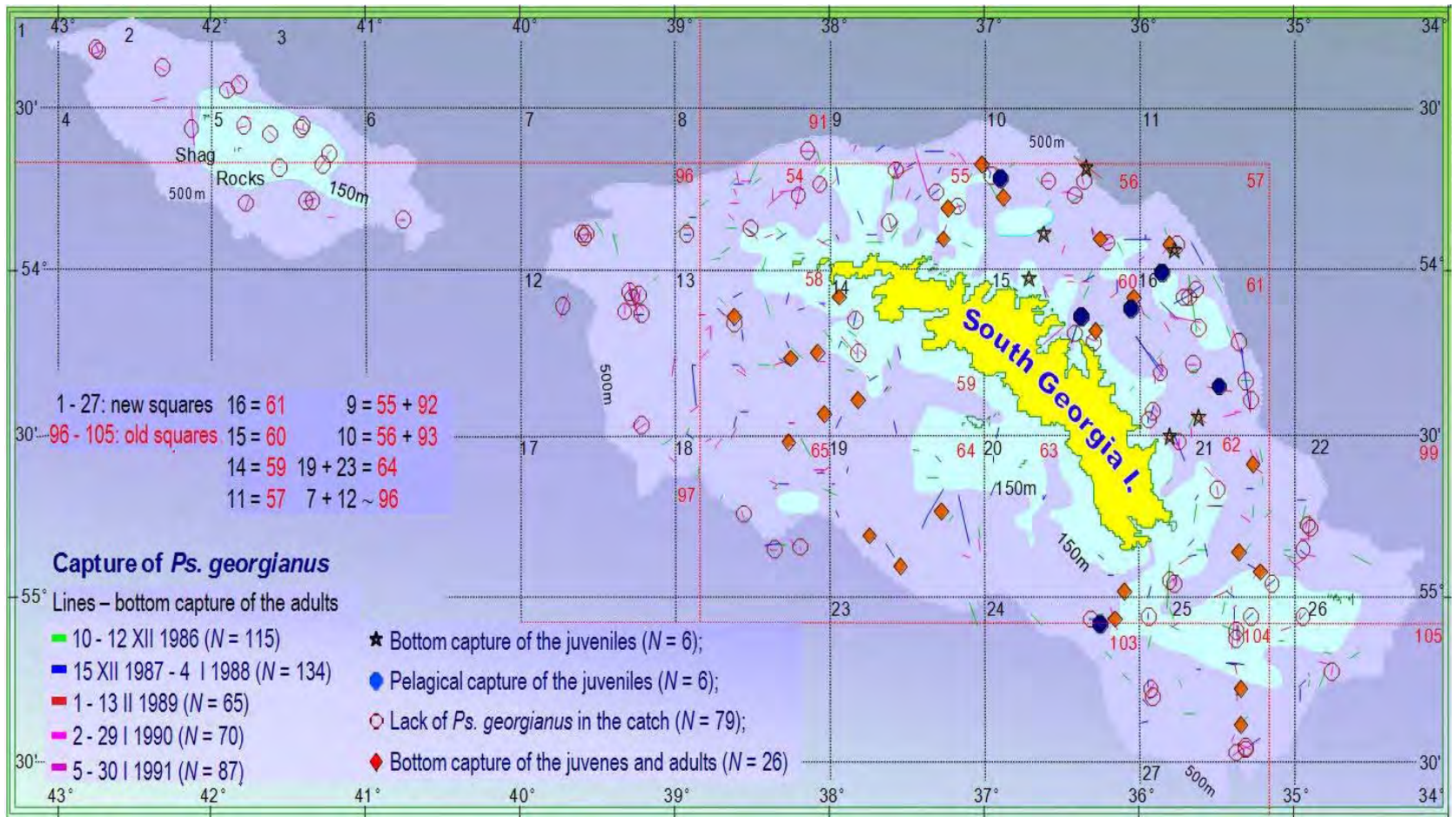

Fig. 4 Controls hauls in the squares of CCAMLR statistical area, No 48.3 on the shelf of South Georgia Island.

Author participated in research of krill and fish in two Antarctic expedition regions of King George, South Orkney and South Georgia Island. Collections were made by the international science team of Fish Stock Assessment on the research vessels (r/v): "Professor Siedlecki", "Professor Bogucki" and "Yuzhmorgeologiya" and the mass trawlers $(\mathrm{m} / \mathrm{t})$ : "Gemini", "Sirius", "Taurus", "Carina", "Libra" and "Hill Cove". The details on ship cruises, stations and haul jobs were described in fishery reports [11-14]. At each station, total catch was estimated and its fish subsamples were chosen. Fish were sorted by species. Measurements of the consumption species included total length (cm), weight $(\mathrm{g})$, sex, maturity, stomach contents and otolith subtraction [12]. The 3-7 cm total length postlarvae of Pseudochaenichthys georgianus, Chaenocephalus aceratus, Champsocephalus gunnari and Parachenichthys georgianus were found on the deck during sampling commercial fish $[12,15]$.

The ages was determined on the base of the results obtained from daily increments count in otoliths, the ontogeny changes displayed by otolith internal and external change of shape with link to change their environments. Age structure was determined from proportion age at total length by applying Gulland' key: length - age to mass measurements.

Optimal numbers of samples: the biomass were estimated from the amount of fish caught by the hauls. One haul-one sample made by trawl net takes the fish from the bottom surface of about $0.07 \mathrm{~km}^{2}$ during usually 30 minutes. South Georgia Island shelf can be covered by 592,813 such samples, although it is not possible to do this, the result of such many samplings are adequately approximated by the result of a smaller number of samples proportional to the size of the zone. From 1988 to 1992, average number of samples, hauls were 65.7 for South Georgia Island (Table 1).

Their numbers are distributed among depth zones proportionally to its bottom surface: $n_{1}=n \cdot \frac{\mathrm{N}_{1}}{\sum \mathrm{N}_{\mathrm{j}}}=65.7$ $\times 9,411 \times(9,411+21,682+11,070)^{-1}=15 ; n_{2}=34 ;$ $n_{3}=17$ (Table 2). To estimate the number of samples, the island's shelf was divided on statistical squares (Fig. 4) and depth layers. For each of them, the control hauls was set in the number proportional to their bottom areas. The surface of the bottom shelf for 
Table 1 Characteristics of the Polish-British fish and krill expedition in the Antarctic, on the Polish research ship: r/v "Professor Siedlecki" 1988, 1989, and on the British trawlers: m/t "Hill Cove" 1990, m/t "Falkland Protector" 1992" [6].

\begin{tabular}{|c|c|c|c|c|c|c|c|}
\hline Year of catch and vessel & 1988, Siedl. & January 1 & 9 "Professo & Siedlecki” & & $\begin{array}{l}\text { January } 1990, \\
\text { Hill Cove }\end{array}$ & $\begin{array}{l}\text { January } 1992 \\
\text { Falk Protect }\end{array}$ \\
\hline Sample type (if bottom $=$ fish) & Bottom & Bottom & Bottom & Pelagic, fish & Pelagic, krill & Bottom & Bottom \\
\hline Island shelf region & $\begin{array}{l}\text { South } \\
\text { Georgia }\end{array}$ & Elephant & $\begin{array}{l}\text { South } \\
\text { Georgia }\end{array}$ & $\begin{array}{l}\text { South } \\
\text { Georgia }\end{array}$ & Eleph-S. Ork. & South Georgia & South Georgia \\
\hline Area of estimating $\left(\mathrm{km}^{2}\right)$ & 32,116 & & 26,742 & & & 29,933 & 27,482 \\
\hline Number of hauls & 128 & 4 & 55 & 10 & 13 & 68 & 74 \\
\hline Hauls time, all (minutes) & & 660 & 1,690 & 300 & 2,250 & 1,780 & 1,944 \\
\hline Trawling length $(\mathrm{km})$ & & 1.25 & 3.19 & 0.66 & 4.84 & 4.22 & 4.5 \\
\hline Type of trawl net & $\mathrm{P}-32 / 36$ & P-32/36 & P-32/36 & WP $16 / 41 \times 4$ & WP $16 / 41 \times 4$ & $V-120$ feed & $V-120$ feed \\
\hline Entry width of the trawl net (m) & 17.5 & 17.5 & 17.5 & 17.5 & 17.5 & 20 & 20 \\
\hline The height of the trawl net $(\mathrm{m})$ & 4.5 & 4.5 & 4.5 & 4.5 & 4.5 & 12 & 12 \\
\hline $\begin{array}{l}\text { Average time of one haul } \\
\text { (minutes) }\end{array}$ & 30 & 140 & 30 & 30 & 173 & 30 & 26 \\
\hline Trawling speed (knots) & 3.5 & 3.5 & 3.5 & 3.5 & 3.4 & 3.75 & 3.5 \\
\hline Trawling speed $\left(\mathrm{km} \cdot \mathrm{h}^{-1}\right)$ & 6.48 & 6.48 & 6.48 & 6.48 & 6.29 & 6.94 & 6.94 \\
\hline Size catch (tons) & 5.820 & 1.120 & 6.766 & 1.353 & 4.645 & 64.660 & 13.726 \\
\hline Total cost of catch $(\$)$ & 8,264 & 1,590 & 9,608 & 1,437 & 8,630 & 91,817 & 19,491 \\
\hline Additional cost of catch $(\$)$ & 1,653 & 318 & 1,922 & 287 & 1,726 & 18,363 & 3,898 \\
\hline Rotary cost of fishing (\$) & 6,612 & 1,272 & 7,686 & 1,150 & 6,904 & 73,454 & 15,593 \\
\hline Cost per sample (\$) & & 318 & 140 & 115 & 531 & 1,080 & 211 \\
\hline Ex-vessel prise $(\$)$ & 7,089 & 1,364 & 8,241 & 789 & 17,804 & 78,756 & 16,718 \\
\hline CPUE (tons $\cdot \mathrm{h}^{-1}$ ) & 0.17 & 0.1 & 0.24 & 0.27 & 0.124 & 0.6 & 0.42 \\
\hline $\begin{array}{l}\text { Conversion from CPUE to } \\
\text { biomass density }\end{array}$ & 8.82 & 8.82 & 8.82 & 8.82 & 9.08 & 7.21 & 7.21 \\
\hline Biomass density (tons $\mathrm{km}^{-2}$ ) & 1.5 & 0.882 & 2.13 & 2.38 & 1.13 & 15.71 & 3.03 \\
\hline Biomass (tons) & 48,643 & & 51,533 & & & 63,159 & 95,710 \\
\hline
\end{tabular}

Table 2 The surfaces of the bottom shelf at South Georgia Island in the depth zones, obtained efficiency catches and separation of the number of control samples to them, in competition of ships for high profits from catch win "Hill Cove", but "Siedlecki" had number of researches 5 times more than "Hill Cove" [17].

\begin{tabular}{|c|c|c|c|c|c|c|c|c|c|c|}
\hline \multirow{2}{*}{$\begin{array}{l}\text { Depth } \\
\text { zones }\end{array}$} & \multirow{2}{*}{$\begin{array}{l}\text { Depth } \\
\text { area }\end{array}$} & \multirow{2}{*}{ Proportion } & \multicolumn{5}{|c|}{ Catch efficiency $(\mathrm{kg} / \mathrm{h})$} & \multirow{2}{*}{$\begin{array}{l}\text { Cost } \\
\mathrm{k}_{\mathrm{j}} \\
\end{array}$} & \multirow{2}{*}{ Optional } & \multirow{2}{*}{$\begin{array}{l}\text { Cost of } \\
\text { catch }\end{array}$} \\
\hline & & & & Siedlecki & I. 1990 & I.1992 Falk & S.Dev & & & \\
\hline$\overline{(m)}$ & $\left(\mathrm{km}^{2}\right)$ & $n_{\mathrm{j}}$ & $\mathrm{x}$ & $2 \times x$ & Hill Cove & Protector & $\mathrm{s}$ & $(\$)$ & $n_{\mathrm{j}}$ & $(\$)$ \\
\hline $50-150$ & 9,411 & 15 & 139 & 278 & 86 & 162 & 97 & 357 & 11 & 3,959 \\
\hline $150-250$ & 21,682 & 34 & 293 & 586 & 878 & 506 & 195 & 417 & 48 & 19,908 \\
\hline $250-500$ & 11,070 & 17 & 126 & 252 & 139 & 437 & 150 & 477 & 18 & 8,378 \\
\hline $50-500$ & 42,163 & 66 & 218 & 436 & 602 & 412 & 104 & & 76 & 32,244 \\
\hline
\end{tabular}

each square and depth layer was calculated and updated with bathymetric measurements [16]. Such a sample divided into zones (3 depth zones in the statistical squares between the geographical meridian hours and parallel half-hours) gave more accurate estimates of the average population than the simple random sampling [8]. The number of samples $n_{j}$ for each square $n_{j}$ were determinate from the bottom area and the volume of water on the shelf in that square. In some squares, the bottom is only in one depth layer, in the other, in two, and in yet other ones, in three depth layers, which result that squares with more depth layers require more numbers of samples.

It also depend from preferences of target fish (Fig. 5) that for each species is different, but in general more fish were at the depth of 150-250 m [12]. It needs more numbers of samples to be well tested. For example, Antarctic fish, Pseudochaenichthys georgianus 
(Fig. 6), occur at different depths, but prefer a depth of 150-250 m (larger performance Table 2) and north eastern shelf of the Island [15]. The variability for fish distributions inform the appropriate record of catches (Table 2), the cost of fishing could be found in the International Data Base Cost of Fishing [18, 19]. The total cost of bottom fishing fish is high at an average of $\$ 1,420$ per tonne of caught. The cost of pelagic fish is lower by about $25 \%$, at an average of $\$ 1,062$ per tonne.

Biomass estimate of South Georgia Icefish were performed with swept area method using survey data. Catch of each haul was standardized to fishing effort (catch per time fishing), then average values were calculated for density of biomass per $\mathrm{km}^{2}$ in each of the statistical areas. Half an hour of catching can catch the surface of $0.06 \mathrm{~km}^{2}$ (equal to entry width of the trawl net $=17.5 \mathrm{~m}$ multiple by length $3.24 \mathrm{~km}$ from haul speed and with conversion 8.82 the catch is changed to biomass density, Table 1). Calculations were made separately for 3 depth zones in each square. It was assumed that the coefficient catchability $q=1$. The calculated biomass over the shelf of South Georgia Island is the sum of the biomass from particular areas. Swept area method is commonly used for biomass estimate from research vessel data $[6,8]$.

In the analysis of costs and benefits, conservation of the species is already taking the fishing constraints depending on the biomass of the species into account. In recent years, the use of bottom fishing was limited to avoid impacts on non-target species [20]. Antarctic fish can be fished only with the pelagic net, which its use cost about $\$ 1,062$ per tonne, that is 2 time less than the cost of bottom ones. But the larger profit is left to bottom catch, because from pelagic catch fisherman in the port receives $\$ 583$ per tonne, and from bottom fishing, more than 2 times: $\$ 1,218$ per tonne [18]. Ban on bottom catches save rare bottom icefish and their environments, because bottom net destroy spawning grounds and sedentary life of ocean. More recently, even entire north east shelf or inshore assessment exclude from fishing.

Krill samples were collected in the ice edge zone, between Elephant Island and South Orkney by industrial hauls net from locations of the presence of krill sonar recorded and by the bongo from a depth of 299 meters to the surface (Fig. 3). The mass of each sample were determined. From each sample of the haul and bongo, sub-sample of 100 individuals of krill were taken to determine the length distribution, maturity structure and the degree of krill feeding. Echograms records were analyzed in relation to the nature of the krill clusters and its biomass. The Standard Length (SL) of krill, from sub-samples was measured to the nearest $1 \mathrm{~mm}$. His weight was calculated from the length with formula: $\mathrm{W}=\mathrm{a} \times \mathrm{L}^{\mathrm{b}}$, with $\mathrm{a}=0.0039$ and $\mathrm{b}=3.1846$, with exception of the 5th stage, for which $\mathrm{a}=0.0054$ and $\mathrm{b}=3.1391$. Stomach contents were determined in 5 degrees, and gonad maturity in 7-point scale. Age was determined by Bhathacharaya method from length frequency. By catch of krill fishery, fish larvae were sorted by species and their numbers were estimated.

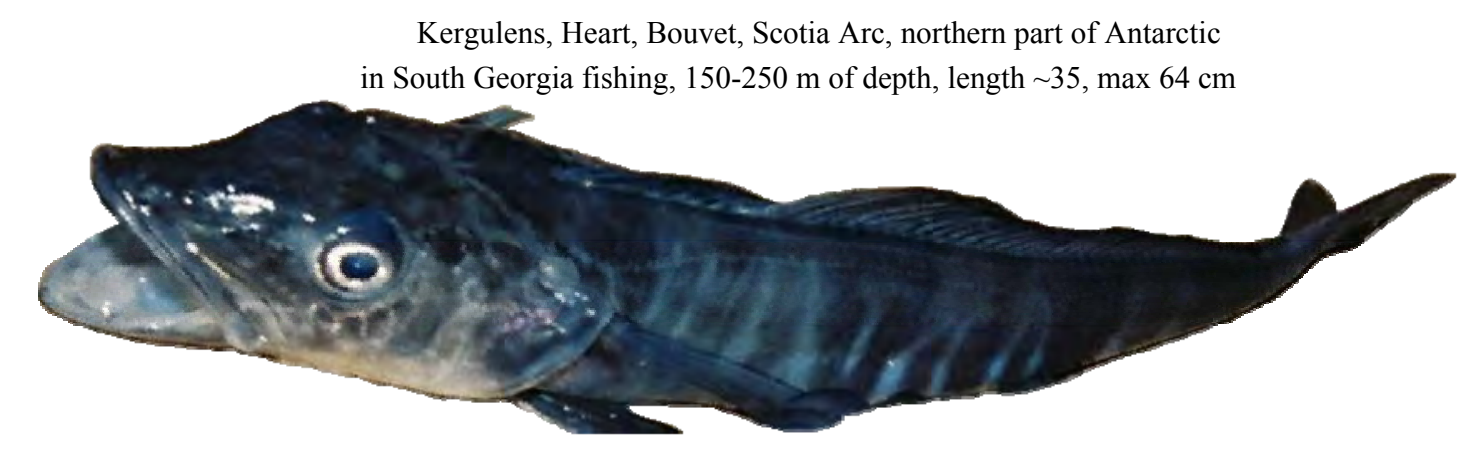

Fig. 5 The mackerel icefish, Champsocephalus gunnari (Channichthyidae). 


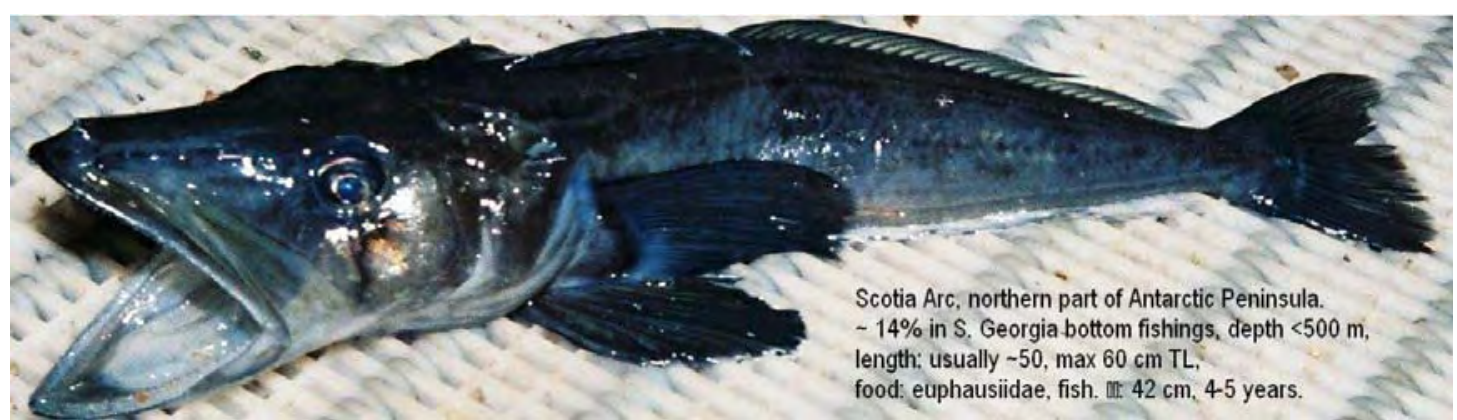

Fig. 6 South Georgia Icefish, Pseudochaenichthys georgianus (Channichthyidae).

\section{Results}

\subsection{Fishing Opportunities from Antarctic Waters}

Fish: The target species before 1988 was mackerel icefish that were caught in tens thousands tons from South Georgia Island (Fig. 7) and in connection with the decline of its stocks, but fishing was closed in 1990. Species growth fast (Fig. 8), but during the last 7 years, fishing mortality of age group exceeded $\mathrm{F}_{0.1}=$ 0.486 [6]. Later fishing, this species has been limited to a few thousand tons. In the season 2010/2011, the limit was 2,305 tons, available for pelagic and bottom trawls, next season in 2011/2012, the limit was 3,072 tons, available only for pelagic hauls. For 2014, the limit was set at 4,635 tonnes (but the total catch was $33 \mathrm{t}$ ) and 2,659 $\mathrm{t}$ for 2015 [20]. Estimated biomass was recorded very high of 106,548 tonnes, based on length frequency (with the largest picks at $36 \mathrm{~cm}$ ) with notation of slowly density increase of adult fish [20]. In the other hand in length frequencies presented size of fish from 1986 to 2013, there was not even one fish above $46 \mathrm{~cm}$ up to $50 \mathrm{~cm}$ TL frequently in 1975-1977 seasons (Fig. 9) [6]. Large increase of biomass will be effect of fast growth rate of all icefish (Figs. 8 and 10), which allow small young $26 \mathrm{~cm}$ fish obtain in one year $37 \mathrm{~cm}$ total length. Fish in $37 \mathrm{~cm}$ is numerous in catch for 2014, but not in domination (Fig. 9) [20]. Dominate fish in $26 \mathrm{~cm}$ that are in 2 age group and concentrated mainly on 2 years old fish [6]. Since pressing, fishery is restricted to pelagic catches, it omit old and large individuals live in the bottom [20]. Biomass of this species based on pelagic data could be overestimated because of pelagic schooling that could be liked with extremal low biomass for bottom areas [6]. Additionally, taking into account the warming temperature at South Georgia Island, there are declined habitat suitability for krill, and condition numerously occurrence of Champsocephalus gunnari could be a moment of plus fluctuation in average decline [21]. In years of poor krill availability, Champsocephalus gunnari's condition is poorer [20]. In lack of krill, large quantities of pelagic icefish are likely to be consumed by fur seals and gentoo penguins, which are normally krill-depended [20].

Catching other commercial fish species, found in low numbers in by-catch were banned as a target and have very low catch limits [22, 23]. For example, Pseudochaenichthys georgianus formerly constituting 14\% of bottom fishing, in 1977/1978: 13,015 t was caught, in 1987/1988 only $401 \mathrm{t}$, in $2004 / 2005,25 \mathrm{t}$, and now from 2007 to 2013, about 1 t, with a little increase to 2 tonnes in 2014 (Figs. 7 and 13) [20]. This same level of bycatch, 0-1 tonnes per year have other additional species of mackerel icefish catches: Chaenocephalus aceratus, Gobionotothen gibberifrons, Notothenia rossii and Lepidonotothen squamifrons.

Catch limit of Pseudochaenichthys georgianus was set to 300 tonnes per year. Biomass assessments of Pseudochaenichthys georgianus was highly variable, but in overall, indicated a reduction, such as in 1976/1977 (36,401 t), in 1988/1989 was half less: $16,529 \mathrm{t}$ and now in 2004/2005 was only 2,948 $\mathrm{t}$ [10]. It declined by about $75 \%$ less than virgin resources $[10,24]$. 
Fishing bottom of deep water toothfish, significantly increased compare to 1970's (Fig. 7), which now is targeted species for fishery. In contrast to icefish, it does not depend on krill across their diet. Old, deep living toothfish feeds on squid, fish (mainly Muraenolepididae) and crustaceans [25, 26]. Young living on a shelf feeds on icefish too. Currently, it is caught much more than krillophagous fish (Fig. 7), but 2 times less.

Icefish on a shelf has a great decline, as above at least $75 \%$. This suppress young of toothfish living shallower on shelf and preying on fish in a greater extent, but now have not large availability to food because that food contain icefish is large reduced [20]. And fishery on a bottom shelf fish is restricted for saving profit from toothfish. To get it, larger channel should start: restrict krill fishery for save fish on a shelf what then save toothfish too.

Also important is bycatch of toothfish in deep sea fishing that are Moridae, about 150 tonnes per year and grenadiers (Macrouridae), about 1,300 tonnes per year in the statistical squares of 48 (Atlantic sector, 48.3: $0-500 \mathrm{~m}: 44.8 \times 10^{3} \mathrm{~km}^{2}$; 500-1800 m: $37.8 \times$ $10^{3} \mathrm{~km}^{2}$ ), 58 (Indian Ocean sector) and 88 (Pacyfic sector), (total surface area $35.7 \times 10^{6} \mathrm{~km}^{2}$ ) [27].

Crabs: There were caught Paralomis spinosissima 299 t (1992/1993) and Paralomis formosa (56 t), but in 2009 much less, consecutively the first and the second species, only $53 \mathrm{t}$ and $9 \mathrm{t}$. Crabs now must be relised free back to water if possible away from catch.

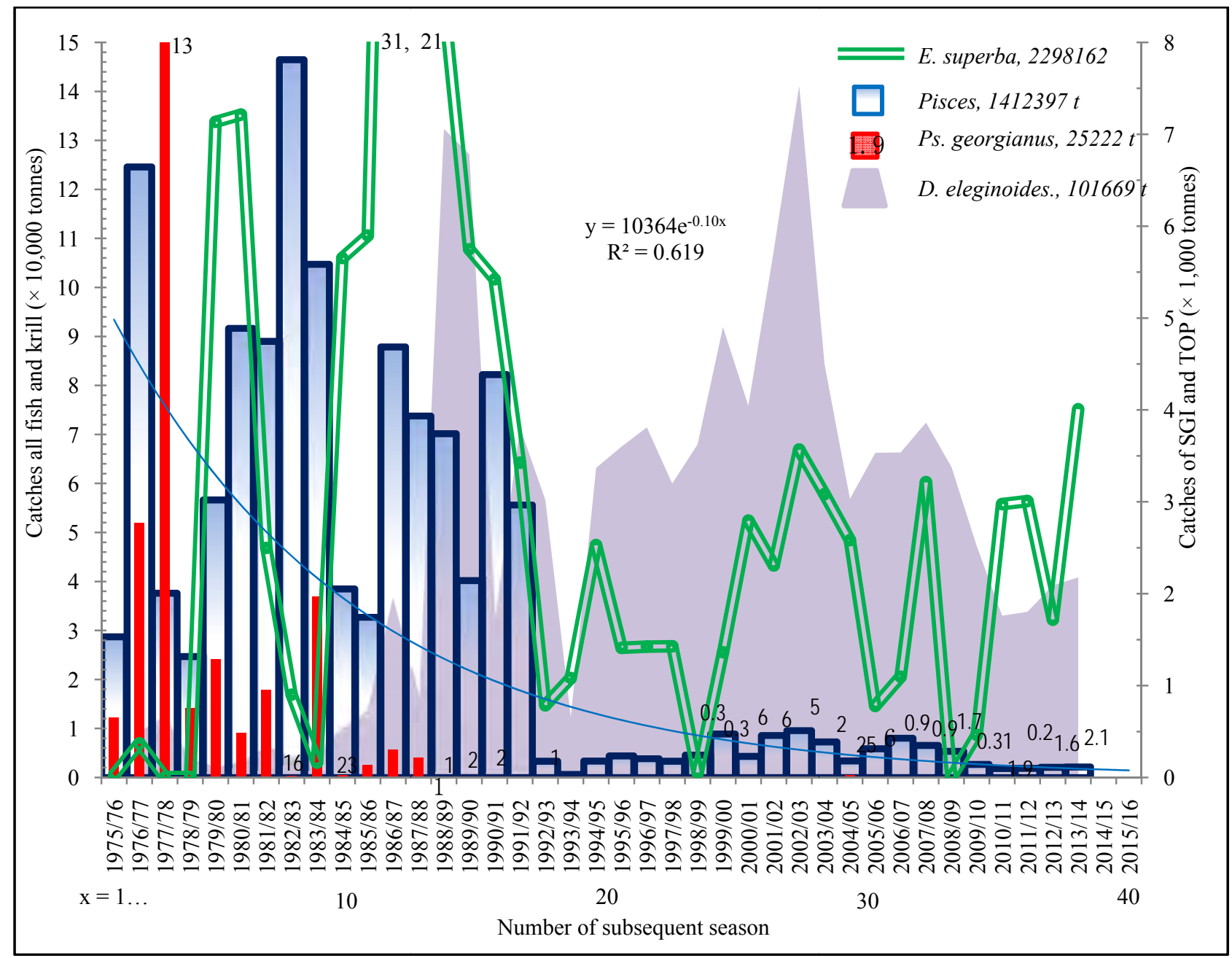

Fig. 7 Total catch of fish, krill, Pseudochaenichthys georgianus (SGI) and Dissostichus eleginoides (TOP) in Antarctica. 
Krill: Towards decline in biomass, thus reduce the catches of Antarctic fish, fishing moved effort on krill, which is the primary food of fish. The gap from reduction of fishing was filled by fishing very large amounts of krill, about 220 thousand tonnes per year. It should be noted that krill are fished in all months all the time throughout the year (sometimes without October and November), on average 25,000 $t$ per month all from Scotia sea. This inhibited the growth of krill eating icefish, which gave the drop of their catch. "In years of poor krill availability, Champsocephalus gunnari condition is poorer", and fishery ships economic withdrawal from fishing of icefish [20].

Profit increase: Antarctic fishermen do not lose their profit by the lack of valuable krillophagous fish they previously over caught, because they gained profits from krill fished in large quantities, up to 100 times by weight compared to the weight of fish they had. Large profit decrease from icefish catches determine the decision of fishing enterprises involved not to deploy their vessels on fishing icefish [6].

\subsection{Changes in Species Compositions of Fish in the Catch}

Whilst former toothfish was only in $1.1 \%$ of bottom fishing, in 1977/1978, $635 \mathrm{t}$ was caught, now is the main species of fish in the amount of more than $60 \%$ of the catch, in average of about 12,000 t (20 time more). Therefore, also it is conversely for krillophagous fish that previously was the basis of catches (up to 90\%), but currently, constituted less than 1 percent in it (Figs. 8 and 13). Fishery move to deep waters start catch a new species.

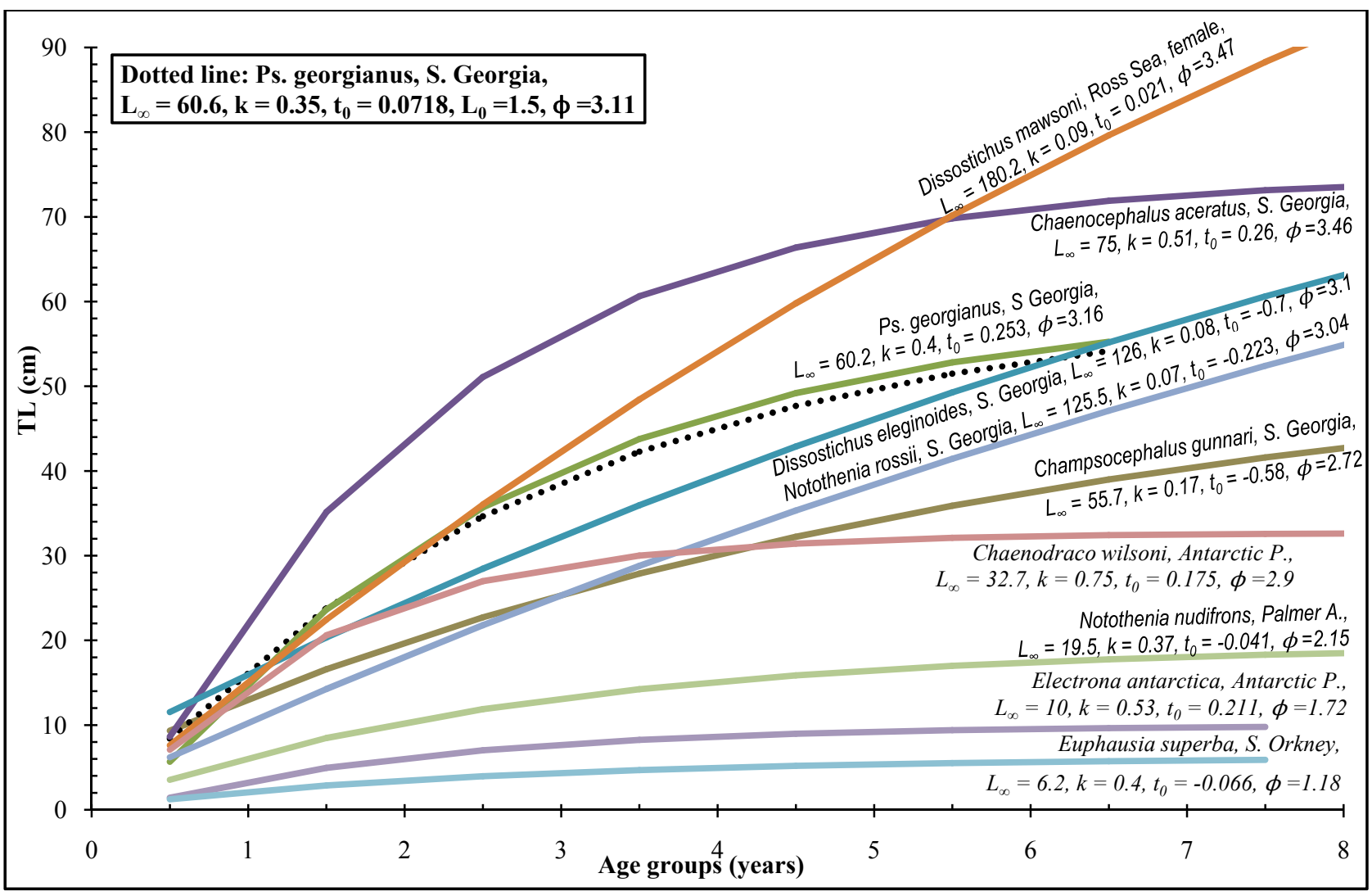

Fig. 8 Growth strategies of Antarctic fish and krill, all icefish growth fast: in the first years achieve large sizes for smaller heat loss (low energy swimming strategy), larvae of Pseudochaenichthys georgianus growth $6 \mathrm{~cm}$ per 4 months, more numerous Chaenocephalus aceratus growth faster than $7 \mathrm{~cm}$, to be not eaten by Pseudochaenichthys georgianus, having larger jaw (consume fish up to $\mathbf{9 8 \%}$ of their own length), most numerous Champsocephalus gunnari is smaller, but produce more energy for faster swimming $[10,15,28]$. 


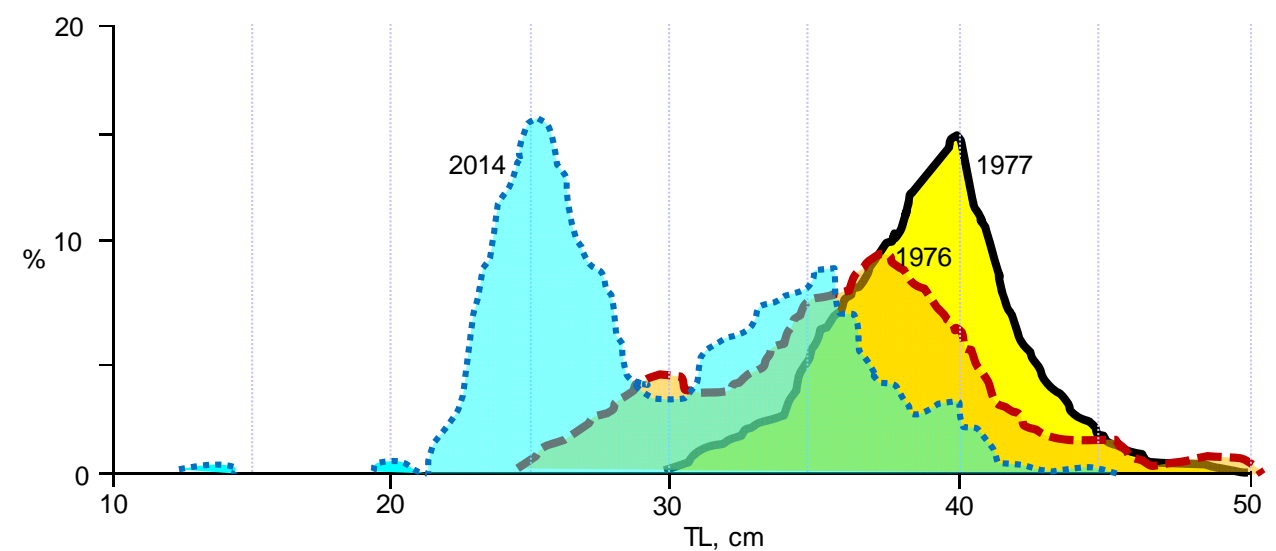

Fig. 9 There are not as large individuals Champsocephalus gunnari in 2014 (dotted line) as in 1976 (braked) and 1977 (solid) $[6,20]$.

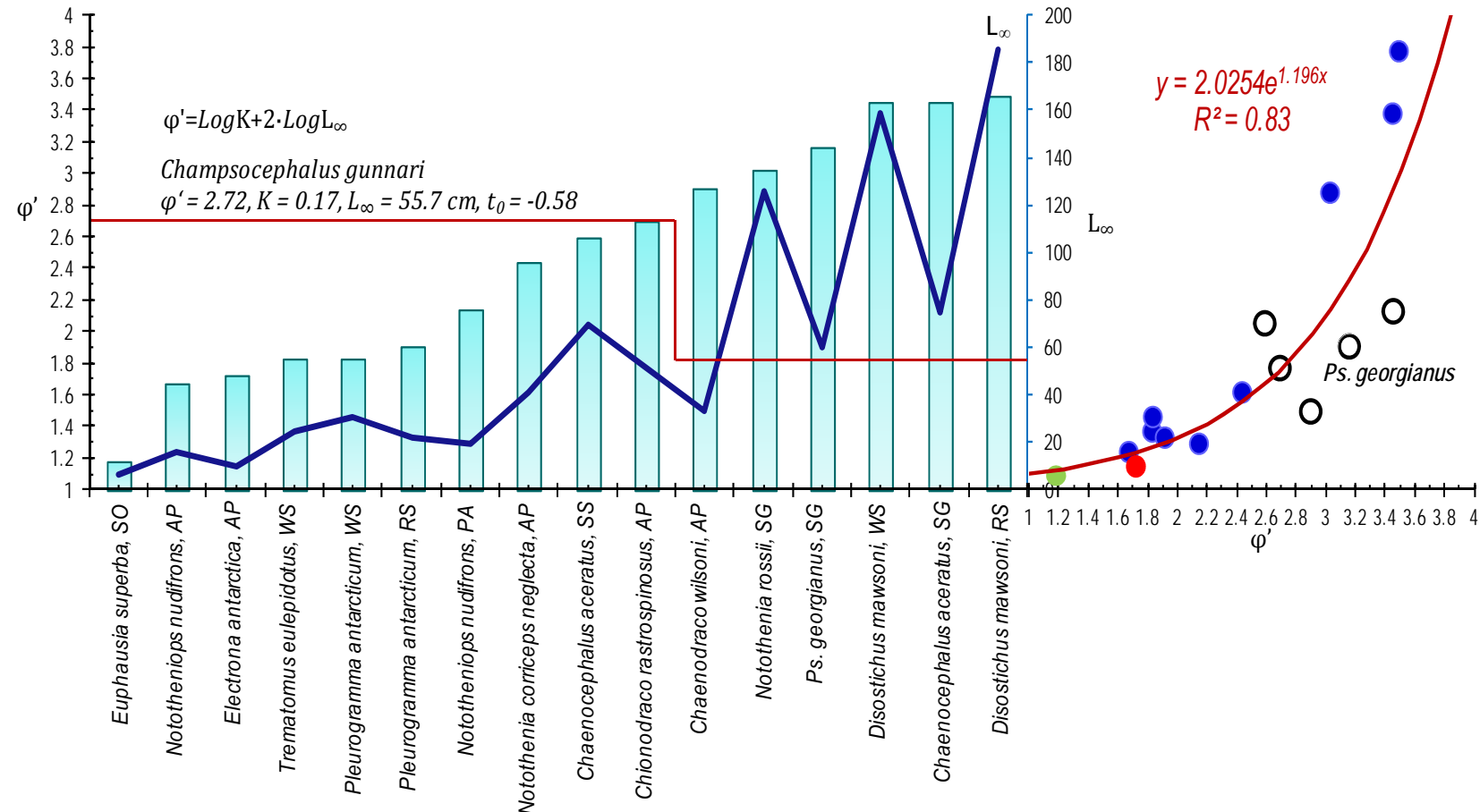

Fig. 10 Growth efficiency indicator of Champsocephalus gunnari is as for whiteblood (white circles on right) and large fish with large $\mathbf{L}_{\infty}$, redblood fish have smaller body growth, but it go for longer life time, krill has smaller growth rate, but it is most numerous, sources of growth parameters, Antarctic Peninsula (AP), Palmer Archipelago (PA), Ross Sea (RS), South Georgia (SG), South Orkney (SO), South Shetland (SS) and Weddel Sea (WS) [29-41].

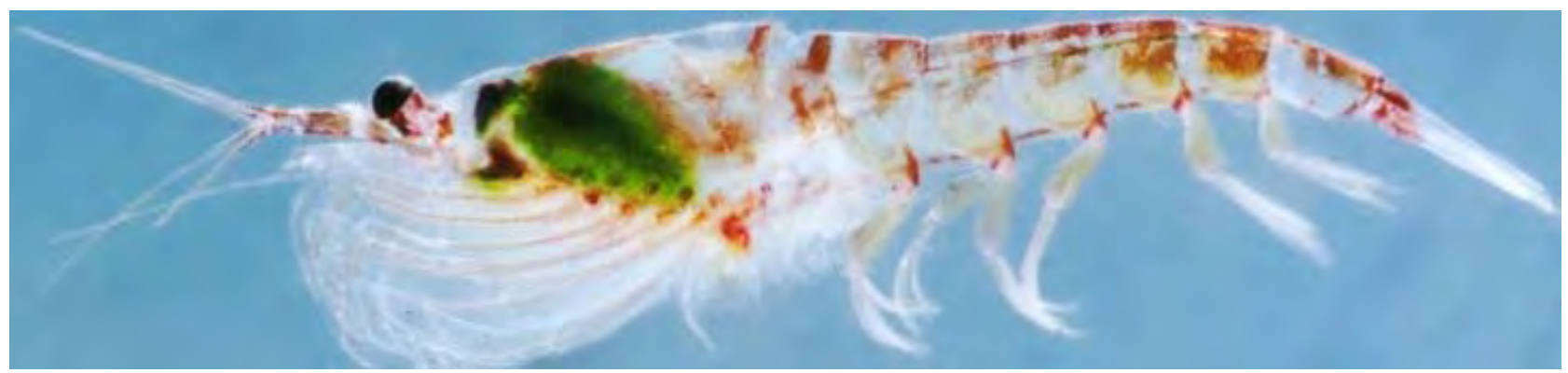

Fig. 11 Krill, Euphausia superba, Dana. 


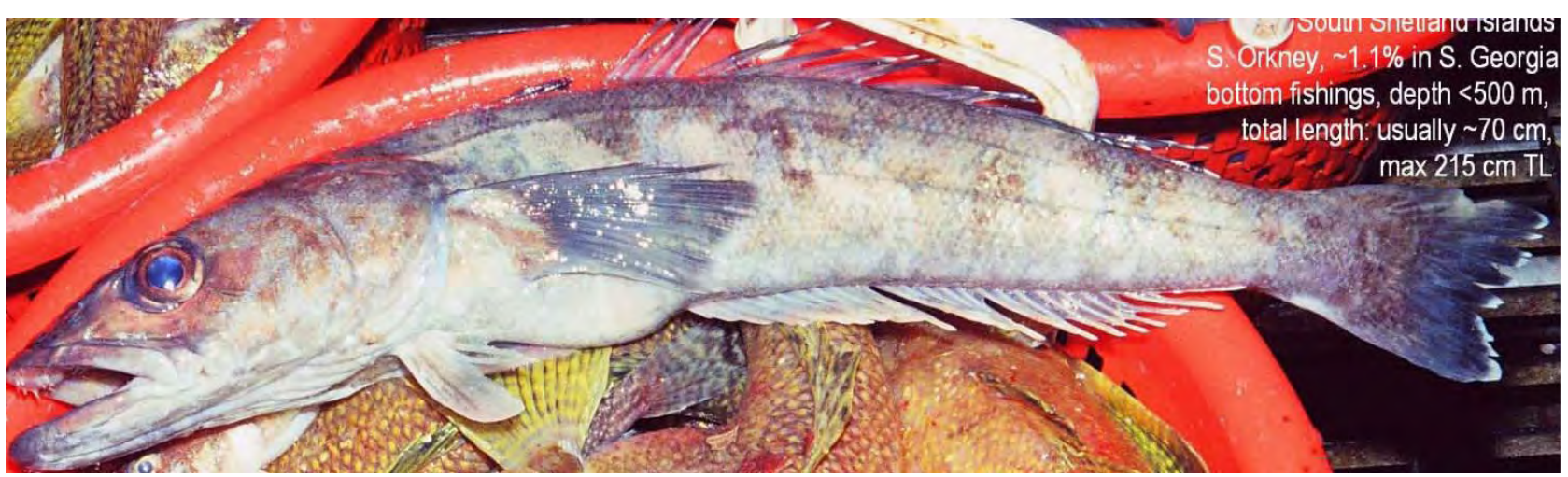

Fig. 12 Patagonian toothfish, Dissostichus eleginoides (Nototheniidae).
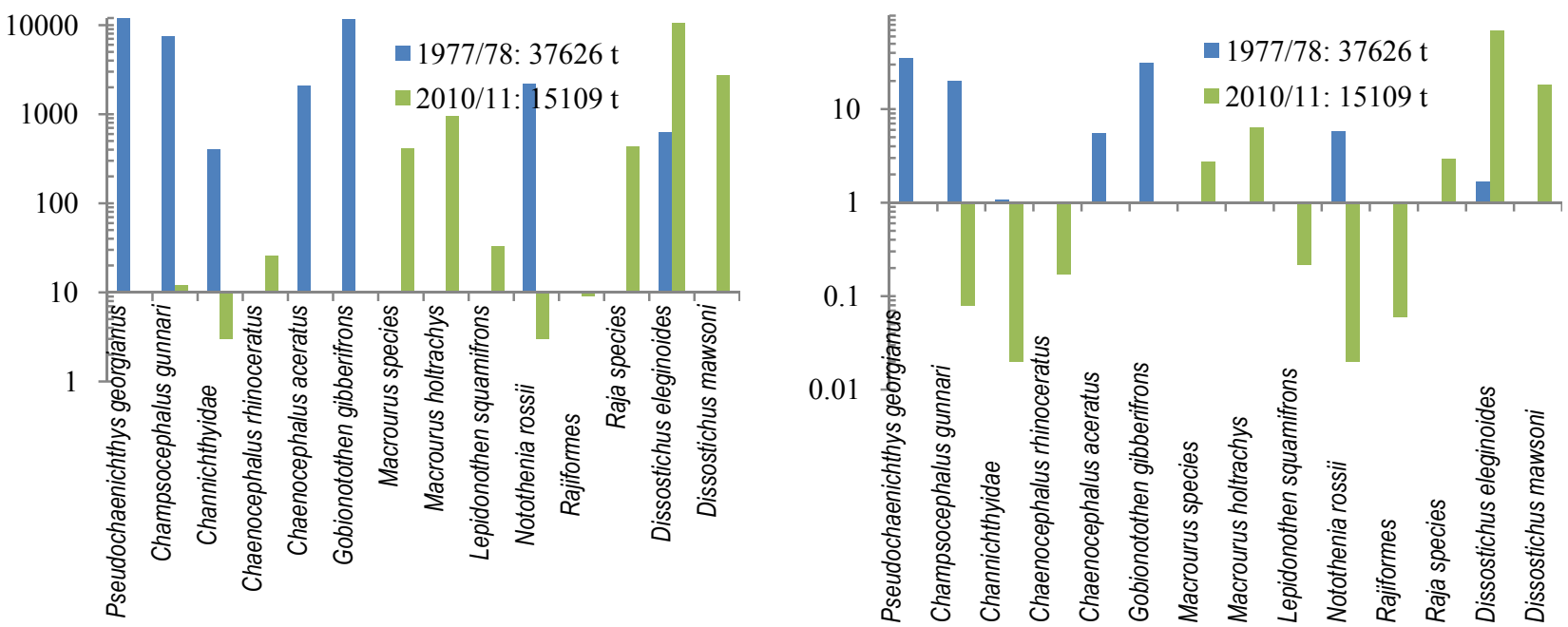

Fig. 13 Fishing in South Georgia Island 1977/1978 and catches in Antarctic ocean 2010/2011 on the right percentage [42].

In particular, shift fishery from shelf to deep water was because that their main species Pseudochaenichthys georgianus, Chaenocephalus aceratus and Gobionotothen gibberifrons almost disappeared, Champsocephalus gunnari and Notothenia rossii were significantly reduced. On deep waters, both species of Dissostichus were become more significant with their bycatches Macrourus and Raja sp. (Fig. 13).

Warming trend at South Georgia Island, promote phytoplankton growth [21]. It is possible to produce from it omega 3 instead of the using of the krill.

\subsection{The Biology and Distribution of the SGI Icefish}

Size of the stock: it is easy from the catch absolute value to estimate fish stocks at the beginning of Antarctic fishery in 1970-1980, when obtained yield from catch was assumed to be between maximum $=$ $50 \%$ of unexploited fish biomass and optimum $=30 \%$ of unexploited fish biomass for sustainable catches. For example, large catch in that period was $4.3 \mathrm{t} \cdot \mathrm{h}^{-1}$, Fig. 17 that give biomass density $38 \mathrm{t} \cdot \mathrm{km}^{-2}$, total biomass 1,139,734 $\mathrm{t}$ and 500,000 $\mathrm{t}$ of yield from South Georgia Island. Happily that, the approach was criticized for stock assessment, the size of fish, age and reproduction. The issue of bycatch were taken into calculations. But it was difficult to estimate from measurements performed during commercial fishing. That measurements comes only from places where icefish concentrated on north east sides of islands (Fig. 2) from spawning ground (with higher number of mature fish) and from target, large consumption fish giving high profits to fisheries (due to the tactics of the commercial vessel to maintain within the area of 
highest fish concentration) $[6,10]$. They have not any information about the other regions of shelf and about young fish (Fig. 17), that were numerous on different sides of island because of its migrations [10, 11, 15]. Juvenile (1 age group, 19-24 cm) recruit to the south of the island before migrating to the northern shelf [10]. The majority of that juvenile fish were recorded from the south-west of South Georgia Island, possible a nursery ground [10].

To exact estimate the biomass of fish, research cruises were arranged every year sampled all Antarctic ocean divided into grid statistical squares at three depth strata $(<150 \mathrm{~m}, 151-250 \mathrm{~m}$ and $>250 \mathrm{~m})$ in regard to study fish stock and biomass [10]. Data of biomasses estimated from that cruises with swept area were approximated by time series equations (Figs. 14 and 15) from which biomass for last 10 years were prognoses. Increasing with an average value 6,240 $\mathrm{t}$ (in account a little increase of SGI catches during 2012-2014) or decreasing to $5,797 \mathrm{t}$, it was in general decreasing in catches of all fish and in biomass (Tables 3-5). Also in main (Fig. 16) food reduce, krill was caught 75,169 t in 2012/2013 - 2 times higher than in previous year [43].

\subsection{The Age Structure in the Length Distribution}

For icefish Pseudochaenichthys georgianus, the

Table 3 Biomass estimates (t) and catches (t) of Pseudochaenichthys georgianus caught in trawls around South Georgia Island in the last row an average biomass and caches, last column for biomass estimate from time series analyses: $\mathbf{y}=B x^{2}+$ $C x+D+E X P\left(-\beta \cdot x \cdot 2^{-1}\right) \cdot\left(A \cdot \sin \left(2 \pi \cdot\left(T^{-1}\right) \cdot x+\varphi\right)+E\right)$; where $B=11.13, C=326.7, D=1295.2, \beta=0.128, A=15,398, T=-0.07, \varphi=$ $-7.3, E=20467, x=1,2 \ldots 40$ time, number of subsequent season with start at 1975/1976 as 1 (Fig. 14) [48].

\begin{tabular}{|c|c|c|c|c|c|c|c|c|c|c|c|c|}
\hline Year & Biomass & Catch & Year & Biomass & Catch & Year & Biomass & Catch & Year & & Biomass: A, $B$ & Catch \\
\hline $1975 / 1976$ & 10,968 & 654 & $1985 / 1986$ & 8,134 & 135 & $1995 / 1996$ & & & $2005 / 2006$ & 9,222 & 4,293 & 6 \\
\hline 1976/1977 & 36,401 & 2,775 & $1986 / 1987$ & 5,520 & 305 & $1996 / 1997$ & 8,615 & & $2006 / 2007$ & 2,131 & 1,846 & 0.9 \\
\hline $1977 / 1978$ & 23,210 & 12,743 & $1987 / 1988$ & 9,461 & 215 & $1997 / 1998$ & 8,615 & & $2007 / 2008$ & 3,029 & 3,143 & 0.9 \\
\hline 1978/1979 & 4,192 & 758 & $1988 / 1989$ & 8,697 & 1 & $1998 / 1999$ & & 0.3 & $2008 / 2009$ & 4,754 & 7,036 & 1.7 \\
\hline $1979 / 1980$ & & 1,289 & $1989 / 1990$ & 3,821 & 1 & $1999 / 2000$ & 4,728 & 0.3 & $2009 / 2010$ & 8,508 & 9,354 & 1.9 \\
\hline 1980/1981 & 14,618 & 488 & 1990/1991 & 5,761 & 2 & $2000 / 2001$ & 2,637 & 6 & $2010 / 2011$ & 8,131 & 7,853 & 0.31 \\
\hline 1981/1982 & 15,786 & 956 & 1991/1992 & 13,469 & 2 & $2001 / 2002$ & 9,352 & 6 & $2011 / 2012$ & 4,944 & 4,888 & 0.2 \\
\hline $1982 / 1983$ & 16,940 & 16 & $1992 / 1993$ & & & $2002 / 2003$ & 2,239 & 5 & $2012 / 2013$ & 5,150 & 4,609 & 1.6 \\
\hline $1983 / 1984$ & 18,484 & 1,967 & $1993 / 1994$ & 8,964 & 1 & $2003 / 2004$ & 9,964 & 2 & $2013 / 2014$ & 7,270 & 8,036 & 2.1 \\
\hline $1984 / 1985$ & 12,537 & 23 & $1994 / 1995$ & & & $2004 / 2005$ & 2,948 & 25 & $2014 / 2015$ & & 11,844 & \\
\hline $1975-1985$ & 17,015 & 2,406 & $1985-1995$ & 7,978 & 83 & $1995-2005$ & 6,137 & 6.4 & $2005-2015$ & 5,904 & 6,290 & 1.7 \\
\hline
\end{tabular}

Table 4 Catches (t) of all fish with percent catches of Pseudochaenichthys georgianus caught in trawls around South Georgia Island, in the last row an average data, from 1975 during 20 years catch were reduced only 2 times, but during next 20 years more than 10 times, parallel Pseudochaenichthys georgianus contribution during first period drop 40 times and during next only 4 times [43].

\begin{tabular}{|c|c|c|c|c|c|c|c|c|c|c|c|}
\hline Year & Catch & SGI(\%) & Year & Catch & SGI(\%) & Year & Catch & SGI(\%) & Year & Catch & SGI (\%) \\
\hline $1975 / 1976$ & 28,732 & 2.28 & $1985 / 1986$ & 32,724 & 0.477 & $1995 / 1996$ & 4,434 & & $2005 / 2006$ & 5,888 & 0.102 \\
\hline 1976/1977 & 124,611 & 1.29 & $1986 / 1987$ & 87,883 & 0.135 & $1996 / 1997$ & 3,865 & & $2006 / 2007$ & 8,051 & 0.011 \\
\hline $1977 / 1978$ & 37,626 & 34.59 & $1987 / 1988$ & 73,795 & 0.543 & $1997 / 1998$ & 3,362 & & $2007 / 2008$ & 6,575 & 0.014 \\
\hline $1978 / 1979$ & 24,705 & 4.469 & $1988 / 1989$ & 70,176 & 0.001 & $1998 / 1999$ & 4,591 & 0.007 & $2008 / 2009$ & 5,387 & 0.032 \\
\hline $1979 / 1980$ & 56,664 & 1.174 & $1989 / 1990$ & 40,208 & 0.002 & $1999 / 2000$ & 8,901 & 0.003 & $2009 / 2010$ & 2,708 & 0.07 \\
\hline 1980/1981 & 91,677 & 1.812 & $1990 / 1991$ & 82,229 & 0.002 & $2000 / 2001$ & 4,345 & 0.138 & $2010 / 2011$ & 1,880 & 0.016 \\
\hline $1981 / 1982$ & 89,036 & 1.074 & $1991 / 1992$ & 55,630 & 0.004 & $2001 / 2002$ & 8,609 & 0.07 & $2011 / 2012$ & 1,907 & 0.01 \\
\hline $1982 / 1983$ & 146,482 & & $1992 / 1993$ & 3,348 & & $2002 / 2003$ & 9,602 & 0.052 & $2012 / 2013$ & 2,111 & 0.076 \\
\hline $1983 / 1984$ & 104,744 & 0.848 & $1993 / 1994$ & 658 & 0.152 & $2003 / 2004$ & 7,299 & 0.027 & $2013 / 2014$ & 2,182 & 0.096 \\
\hline $1984 / 1985$ & 38,517 & 2.848 & $1994 / 1995$ & 3,389 & & $2004 / 2005$ & 3,416 & 0.732 & $2014 / 2015$ & & \\
\hline $1975-1985$ & 74,279 & 6.0 & $1985-1995$ & 45,004 & 0.165 & $1995-2005$ & 5,842 & 0.147 & $2005-2015$ & 4,077 & 0.047 \\
\hline
\end{tabular}


Table 5 Biomass (t) all fish and \% biomass of Pseudochaenichthys georgianus (13.7\%) caught in trawls around South Georgia Island.

\begin{tabular}{|c|c|c|c|c|c|c|c|c|c|c|c|}
\hline Year & Biomass & SGI(\%) & Year & Biomass & SGI(\%) & Year & Biomass & SGI(\%) & Year & Biomass: & SGI $(\%)$ \\
\hline $1975 / 1976$ & 92,562 & 11.9 & $1980 / 1981$ & 123,368 & 11.9 & $1984 / 1985$ & & & $1988 / 1989$ & 51,533 & 16.9 \\
\hline $1976 / 1977$ & 323,703 & 11.2 & $1981 / 1982$ & 133,230 & 11.9 & $1985 / 1986$ & 66,132 & 12.3 & $1989 / 1990$ & 63,159 & 6.1 \\
\hline $1977 / 1978$ & 72,862 & 31.9 & $1982 / 1983$ & & & $1986 / 1987$ & 94,277 & 5.9 & $1990 / 1991$ & 69,090 & 8.3 \\
\hline $1978 / 1979$ & 20,452 & 20.5 & $1983 / 1984$ & 156,000 & 11.9 & $1987 / 1988$ & 48,643 & 19.5 & $1991 / 1992$ & 95,710 & 14.1 \\
\hline $1975-1979$ & 127,395 & 18.9 & $1980-1984$ & 137,533 & 11.9 & $1984-1988$ & 69,684 & 12.6 & 1988-1992 & 69,873 & 11.4 \\
\hline
\end{tabular}

Table 6 Biomass (t) and CPUE $\left(t \cdot h^{-1}\right)$ of Pseudochaenichthys georgianus caught in trawls around South Georgia Island, in the last row an average data.

\begin{tabular}{|c|c|c|c|c|c|c|c|c|c|c|c|}
\hline Year & Biomass & CPUE & Year & Biomass & CPUE & Year & Biomass & CPUE & Year & Biomass & CPUE \\
\hline $1975 / 1976$ & & & $1985 / 1986$ & 27,629 & 0.08 & $1995 / 1996$ & & & $2005 / 2006$ & 2,125 & 0.004 \\
\hline $1976 / 1977$ & 130,136 & 0.61 & $1986 / 1987$ & 13,927 & 0.044 & $1996 / 1997$ & & & $2006 / 2007$ & 1,175 & 0.004 \\
\hline $1977 / 1978$ & 220,457 & 0.754 & $1987 / 1988$ & 52,618 & 0.384 & $1997 / 1998$ & & & $2007 / 2008$ & 3,029 & 0.005 \\
\hline $1978 / 1979$ & 15,520 & 0.058 & $1988 / 1989$ & 7,752 & 0.024 & 1998/1999 & & & $2008 / 2009$ & 4,754 & 0.007 \\
\hline $1979 / 1980$ & 33,253 & 0.108 & $1989 / 1990$ & & 0.001 & $1999 / 2000$ & & 0.001 & $2009 / 2010$ & 16,262 & 0.028 \\
\hline 1980/1981 & 20,534 & 0.067 & 1990/1991 & 5,024 & 0.016 & $2000 / 2001$ & 5,054 & 0.016 & $2010 / 2011$ & 8,132 & 0.021 \\
\hline $1981 / 1982$ & 39,428 & 0.131 & $1991 / 1992$ & & & $2001 / 2002$ & 1,415 & 0.003 & $2011 / 2012$ & 4,944 & 0.011 \\
\hline $1982 / 1983$ & 720 & 0.002 & $1992 / 1993$ & & & $2002 / 2003$ & 4,233 & 0.014 & $2012 / 2013$ & 5,150 & 0.008 \\
\hline $1983 / 1984$ & 32,263 & 0.492 & $1993 / 1994$ & 17,977 & 0.058 & $2003 / 2004$ & 995 & 0.003 & $2013 / 2014$ & 1,566 & 0.005 \\
\hline $1984 / 1985$ & 3,282 & 0.012 & $1994 / 1995$ & & & $2004 / 2005$ & 22,994 & 0.041 & $2014 / 2015$ & & \\
\hline $1975-1985$ & 55,066 & 0.248 & 1985-1995 & 20,821 & 0.087 & $1995-2005$ & 6,938 & 0.015 & $2005-2015$ & 5,237 & 0.01 \\
\hline
\end{tabular}

research voyage provided missing first 3 age groups for growth equation (Figs. 17 and 18) that needed for understanding length frequency data and analyze it for planning sustainable fisheries. For example, in the years 1991 to 1992 , there were no large and old fish, which at the beginning of the fishing period were numerous. The total length of SG Icefish Pseudochaenichthys georgianus within 14 years of research (with maturity), from the 1976/1977 season to the 1991/1992 season, has dropped down from 50 $\mathrm{cm}$ to $40 \mathrm{~cm}$ (Figs. 17-27). With the age structures, obtained during this 14 years of research, the average length of Pseudochaenichthys georgianus for younger age groups: 0 years, 1 years, 2 years and 3 years increasing with about $3 \mathrm{~cm}$ and decreasing for age groups 4 years, 5 years and 6 years (giving a reduction of about $2 \mathrm{~cm}$ ) (Fig. 28). Regular fishing reduced the numbers of older fish, which causes faster growth of younger fish.

For younger fish, removing old fish determine the smaller intraspecific competition for food and for living space. Large food supply causes juveniles growth a little faster in the range of individual variability (Fig. 28). Length and age frequency show that in heavy exploitations period 1976-1978, 3-4 year old and mature adults were removed by the Antarctic fishery (Table 3, Figs. 17, 21, 25 and 26). Due to the tactics of the commercial vessel to maintain highest catch, they were removed in fishing season from November-February, from concentrations on spawning ground in north-east of the island "higher numbers of stage 3 fish were caught to the east", "larger and older fish migrating to the northern shelf" (Figs. 17, 25 and 26) $[6,10]$. Reports indicate that most spawning occurs northeast, which is close to the shelf shore waters [44]. They were removed without giving possibility for spawning "fishes begin to spawn from April, May", "most icefish spawn in January/February-May/June" $[44,45]$. High intensity of the exploitation resulted in a decline of the stock of fish belonging to older age groups [6]. After high caught, follows lower caught in the cycle (Fig. 15). This same is in age structure in a 
period of low fishing, there were cohort marked as numerous year after year: cohort numerously hatch in $1988 / 1989$ were numerous as age groups $1-3$ in 1989/1990, 1990/1991 and 1991/1992 (Figs. 18 and 22). Their parents age group of 3 in 1987/1988 were from strong cohort too (Figs. 18 and 21). It is not so for older fish in the period of high fishing: age group of 4 years that dominated every year, after high level fishing in 1976-1979, their number were significantly decreased and their domination were broken (Table 3, Fig. 21). They were more appeared (but not to domination level) in 1983/1984 after almost fishing break during 1982/1983: from 13 thousand $t$ per year to only $16 \mathrm{t}$ (Table 3). This confirm cohort comparison: earlier one living in 1975-1984, there were more fish in age group of 4 years while in latter living in 1985-1992, there were more younger 3 year old fish (Fig. 22). In both cases, domination of 4 and 3 years fish was very high that were maintained and continued in next descendant cohort by the increased number of brood (despite the high mortality rate, Fig. 15). Age structure show that stock Pseudochaenichthys georgianus after large catch in 1977 was consisted mainly on 3 years old fish. Catches depended on high grow of fish from one age group. On one cohort of fish in age of 4 , that growth to length about $52 \mathrm{~cm}$, or fish in age of 3 years growth to about $45 \mathrm{~cm}$, or fish in age of 2 years growth to about $35 \mathrm{~cm}$, or even on fish in age of

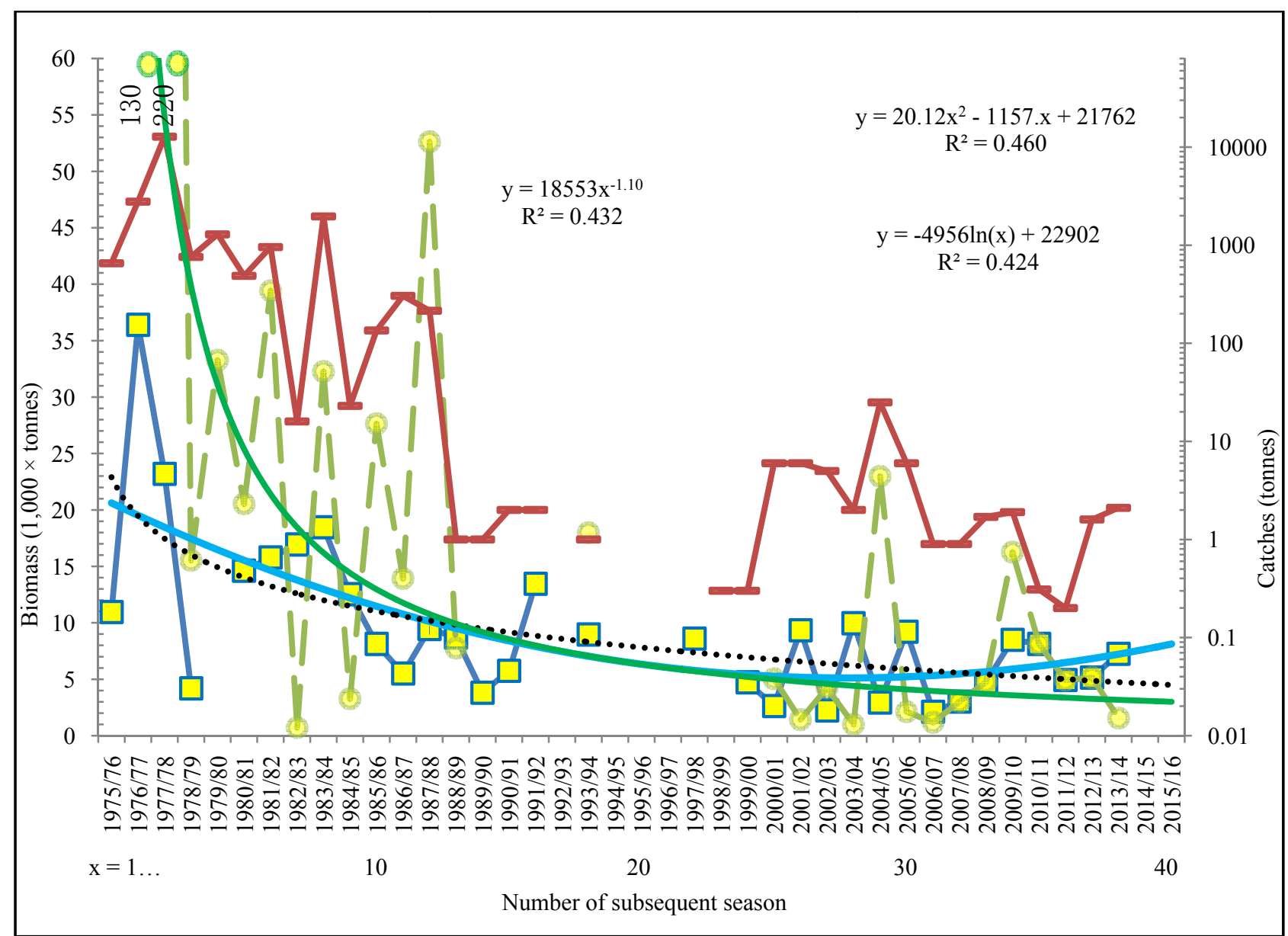

Fig. 14 Biomass estimate with "swept area" from research (squares) from CPUE (circles) compared to catches (line sections) of Pseudochaenichthys georgianus from South Georgia Island, after large catches of Polish and German vessels in 1977-1979 and 1984, species biomass decline to low 4-8 thousand tones today, in prognosis for next year, the biomass increase a little rather than further decrease, because the biomass increased a little in last years, the biomass has 4 years periodic changes [43]. 


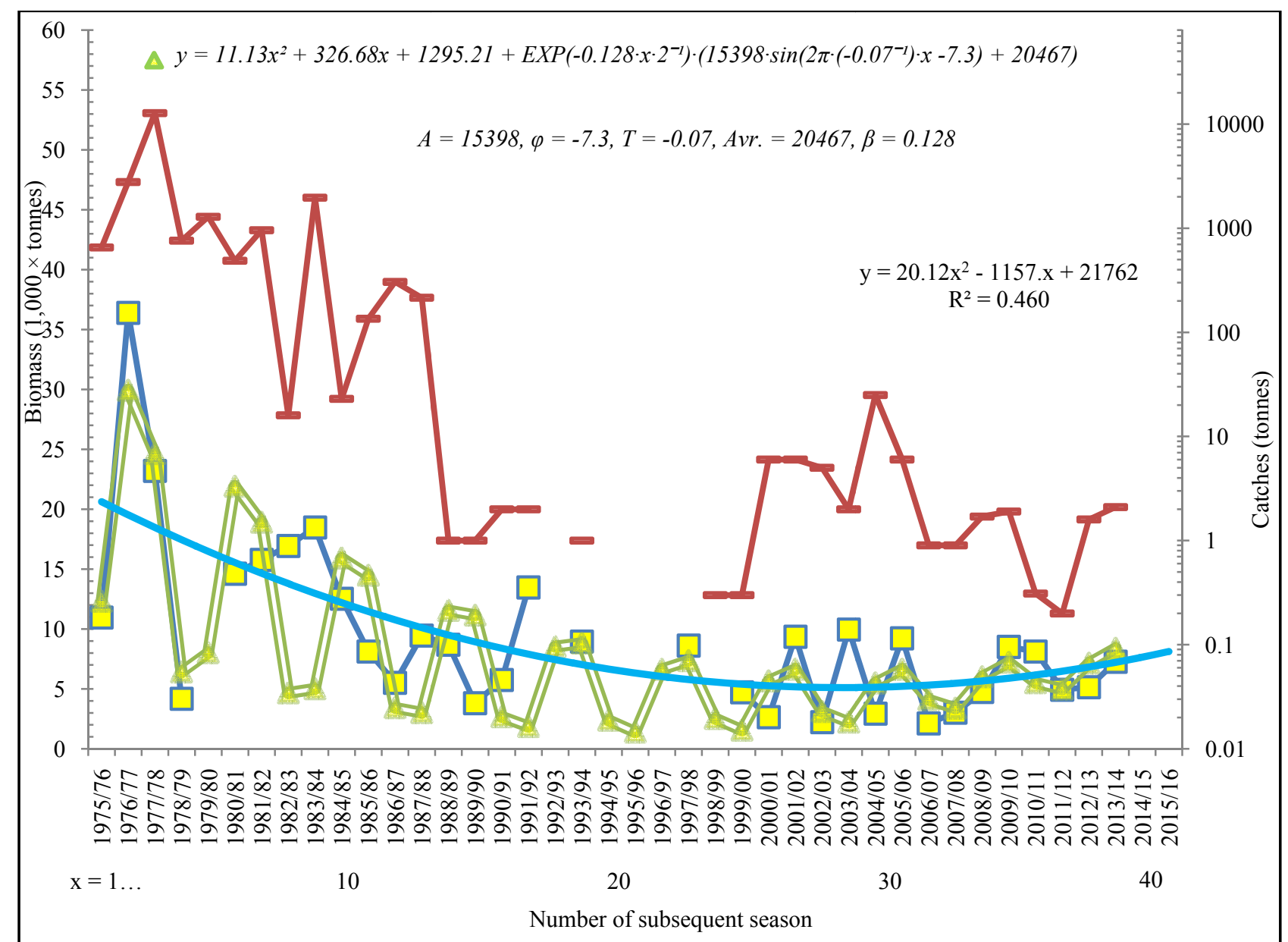

Fig. 15 Biomass of Pseudochaenichthys georgianus show periodic changes: peaks every four year achieved by reproduction cycle during fish life ( 0 postlarvae, 1 and 2 year old young's and 3 year old spawning fish) in fitted (doubled line) periodic component $A \cdot \sin \left(2 \pi \cdot\left(-0.07^{-1}\right) x+\varphi\right)$ and decrease with mortality rate $\beta$ in proportion of exponential decay component $=$ $\exp \left(-\beta x \cdot 2^{-I}\right)$ and component trend of polynomial arousing derived from the hatching of fish and their somatic growth.

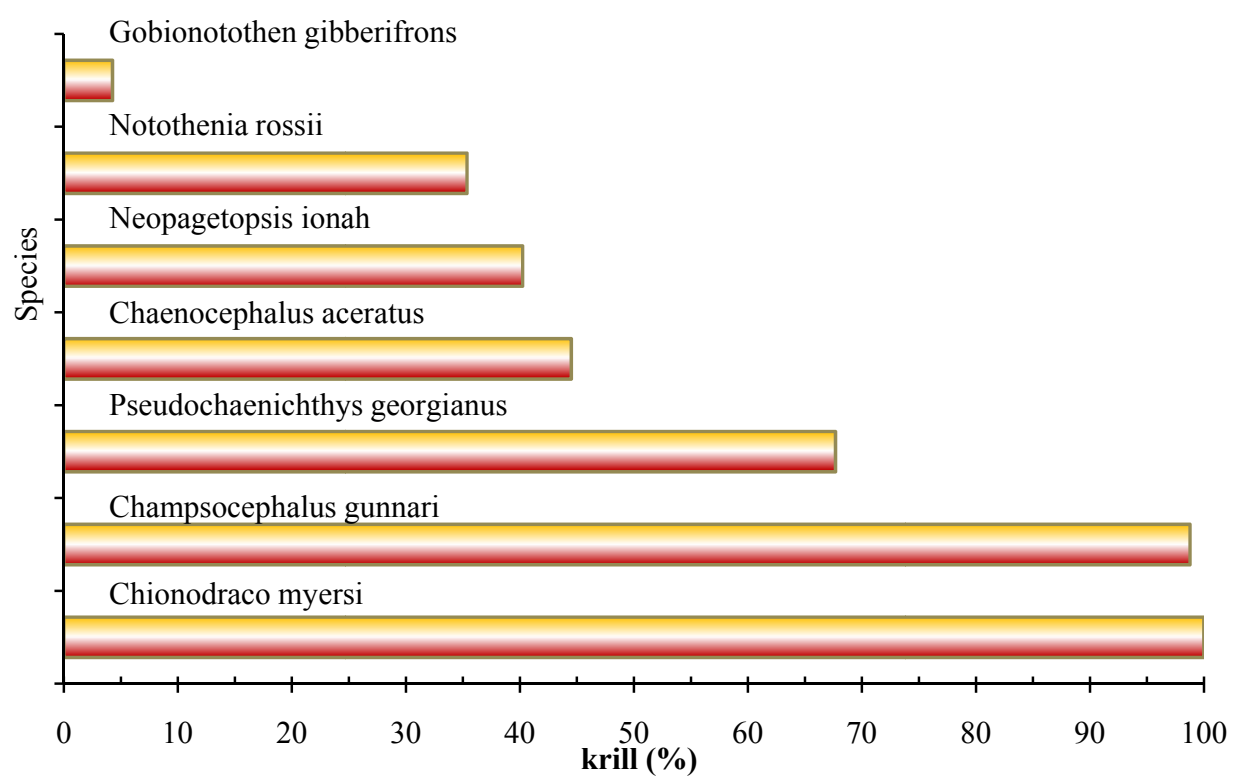

Fig. 16 Percent of krill in food of some finfish from research of 2008/2009 AMLR survey off S. Orkney I. [14]. 


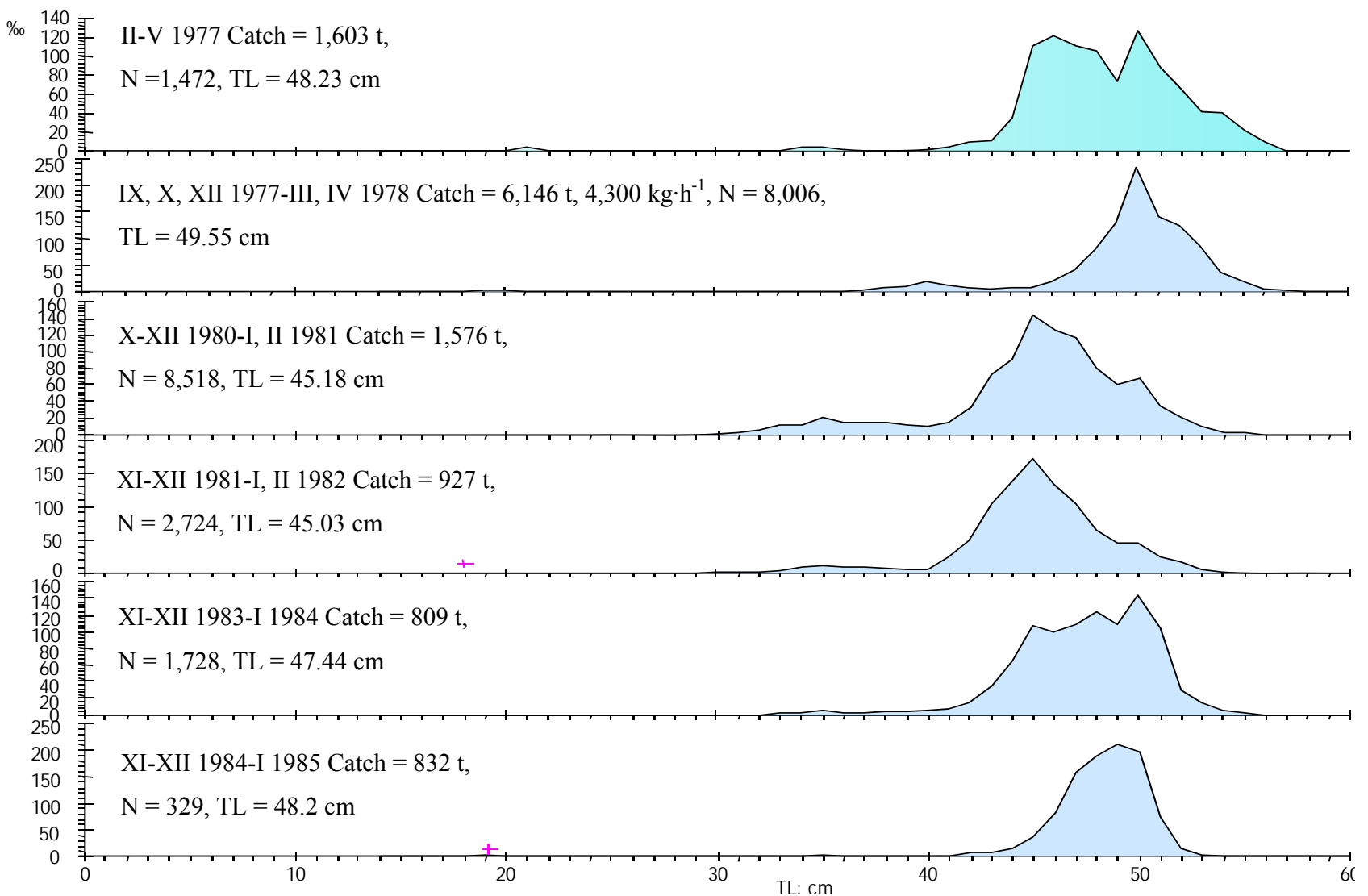

Fig. 17 In commercial caches to get the highest profits, fish were caught only from the places usually inhabited by large fish (the tactics of the commercial vessel), there were no data about the juvenile and young fish, that were needed for estimate catches limits, biomass estimates on large fish became large overestimated [6].

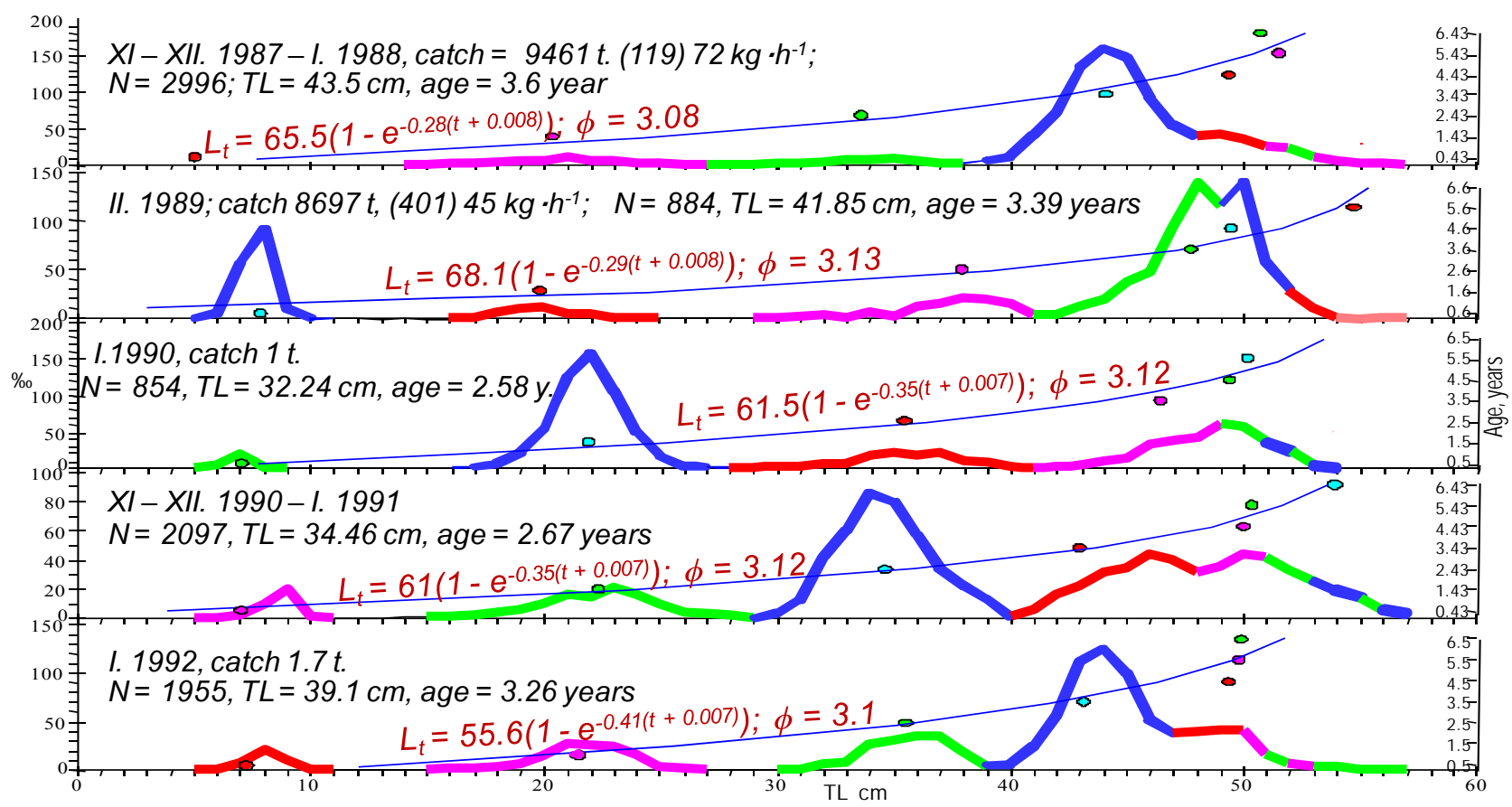

Fig. 18 Length frequency of fish Pseudochaenichthys georgianus, the research team carried out during the international scientific cruises determining fish stocks on the shelf of South Georgia Island, strong cohort show yearly growth rate of fish from $7 \mathrm{~cm}$ juveniles until they became adults $(43 \mathrm{~cm}$ spawning parents, Fig. 25 for postlarvaes of $7 \mathrm{~cm}$ juveniles). 


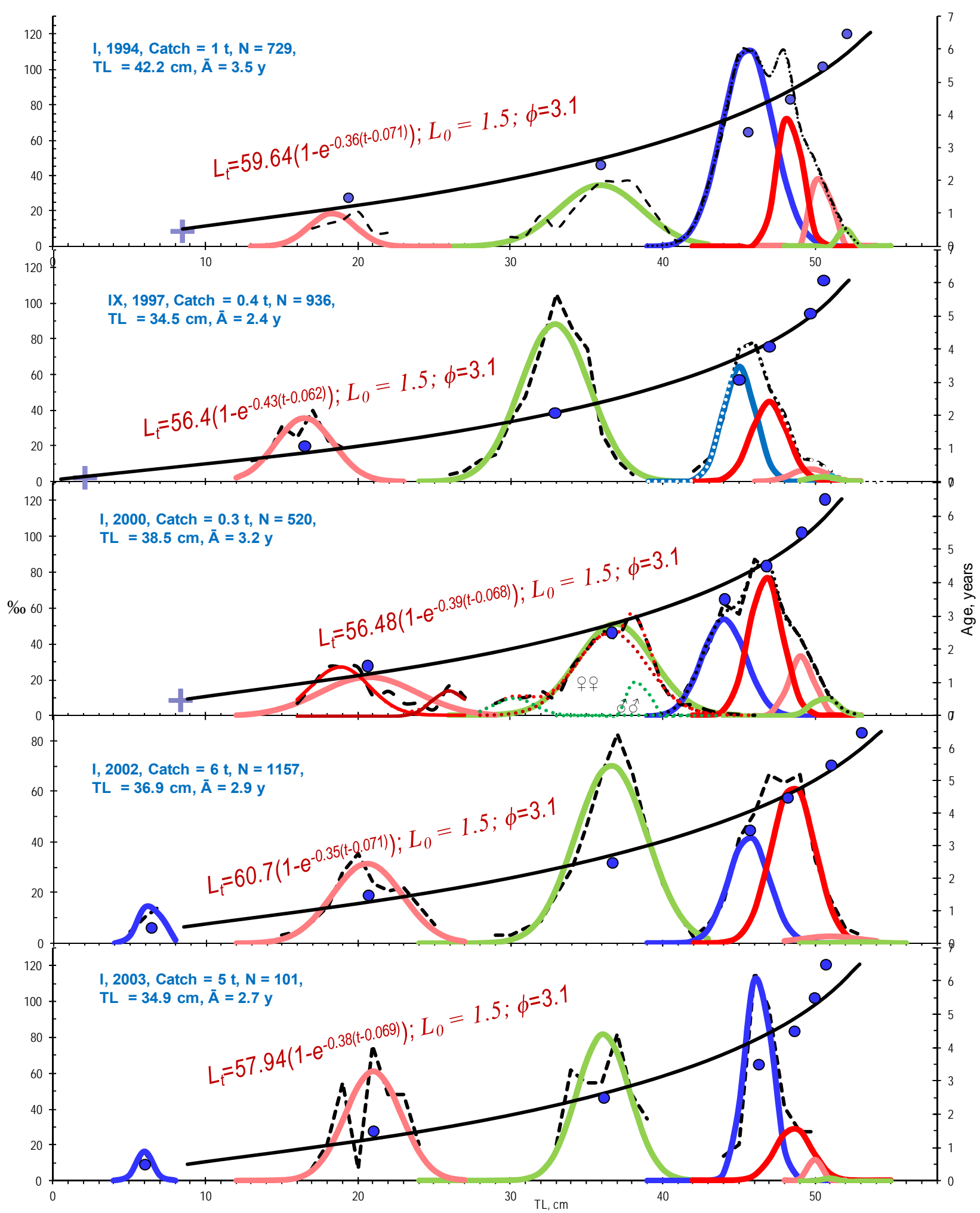

Fig. 19 Estimate age group and growth parameters from length frequency as the last length group indicate consisting 4 age groups. 


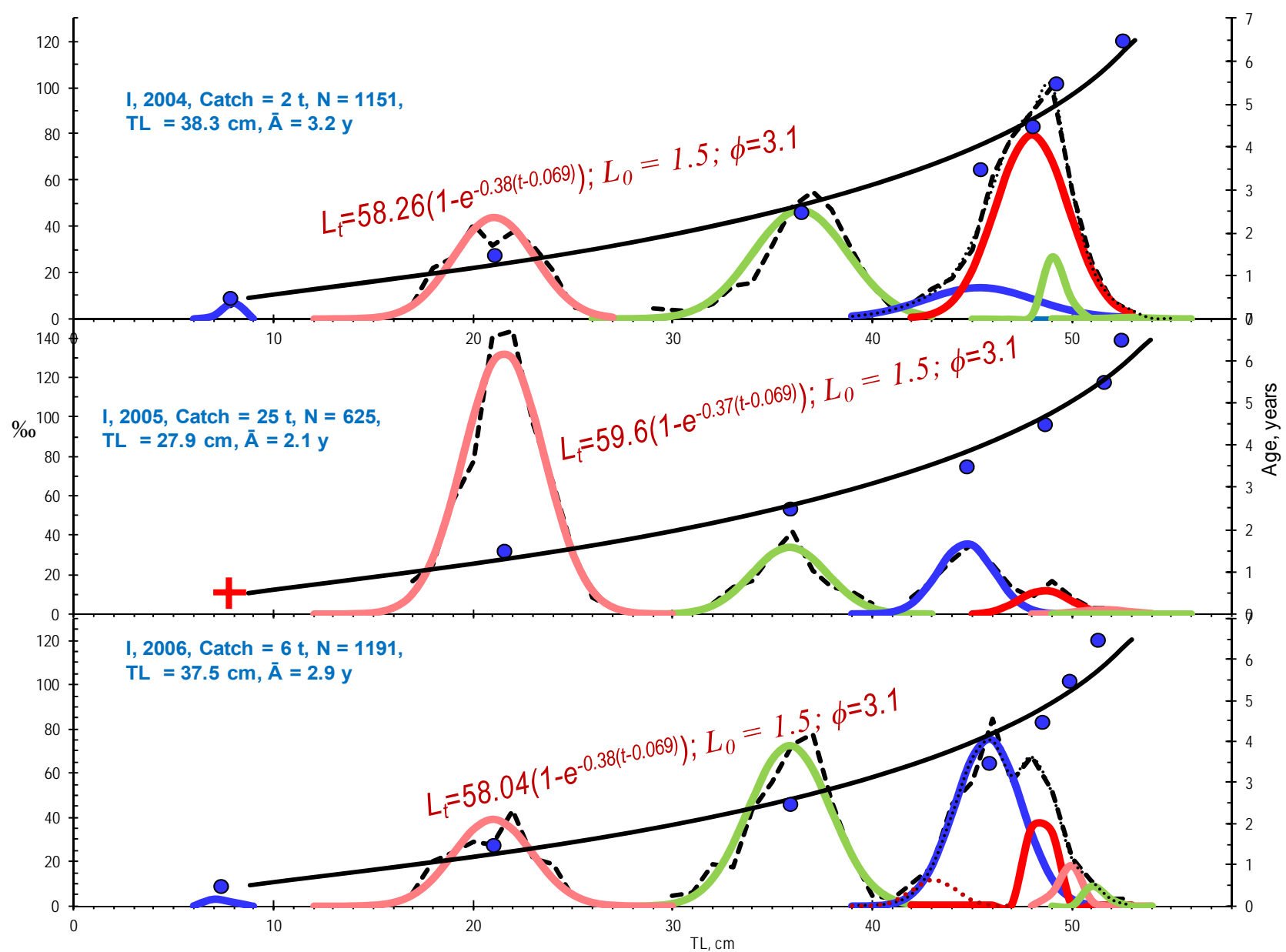

Fig. 20 Estimate age group and growth parameters from length frequency as the last length group indicate consisting 4 age groups, it is confirm with findings that last length group accumulate 4 distant normal distributions in otolith mass, improve of the parameters of components normal distributions by minimize square differences between empirical data and summation of normal distributions of age groups allow to find even negative growth of length in older icefish.

1 years growth to about $22 \mathrm{~cm}$, which were numerous in 1989/1990 season. More considerable numbers of cohorts were in 1983/1984 and 1990/1991 after lowering level of catch to $16 \mathrm{t}$ in $1982 / 1983$ and to one $t$ in 1988/1989 (Figs. 21 and 22). Changes of age-length structure were very sensitive on level of fishing eager to catch that large fish fishing on their ground. Although the target fish was mackerel icefish, but those fish were much smaller, mainly $25 \mathrm{~cm}$, and Antarctic fishers were more proud from caught large semi pelagic and bottom fish having higher prices on market than 2 times smaller pelagic fish [5]. Decrease of average age of fish indicates overfishing. In the sea, every year after fishing season, there remains smaller individuals, which decrease average lengths older and larger fish in the stock. In order to check further appearing of domination cohorts, the age structure was derived from analysis of length frequency fish cough in 1994-2006 by fitting to them normal distributions of age components.

\subsection{Difference in Geographical and Vertical Occurrence of Age Groups and Interspecies Interactions}

That reduction of old fish during high level of icefish explotation in 1976-1984 shows their different geographical distribution from young fish. During that period, the catches were from concentrations of large fish on north-east shelf of island. Although the target species dominated on western of north and south sides of island (Figs. 29-31), that species were 

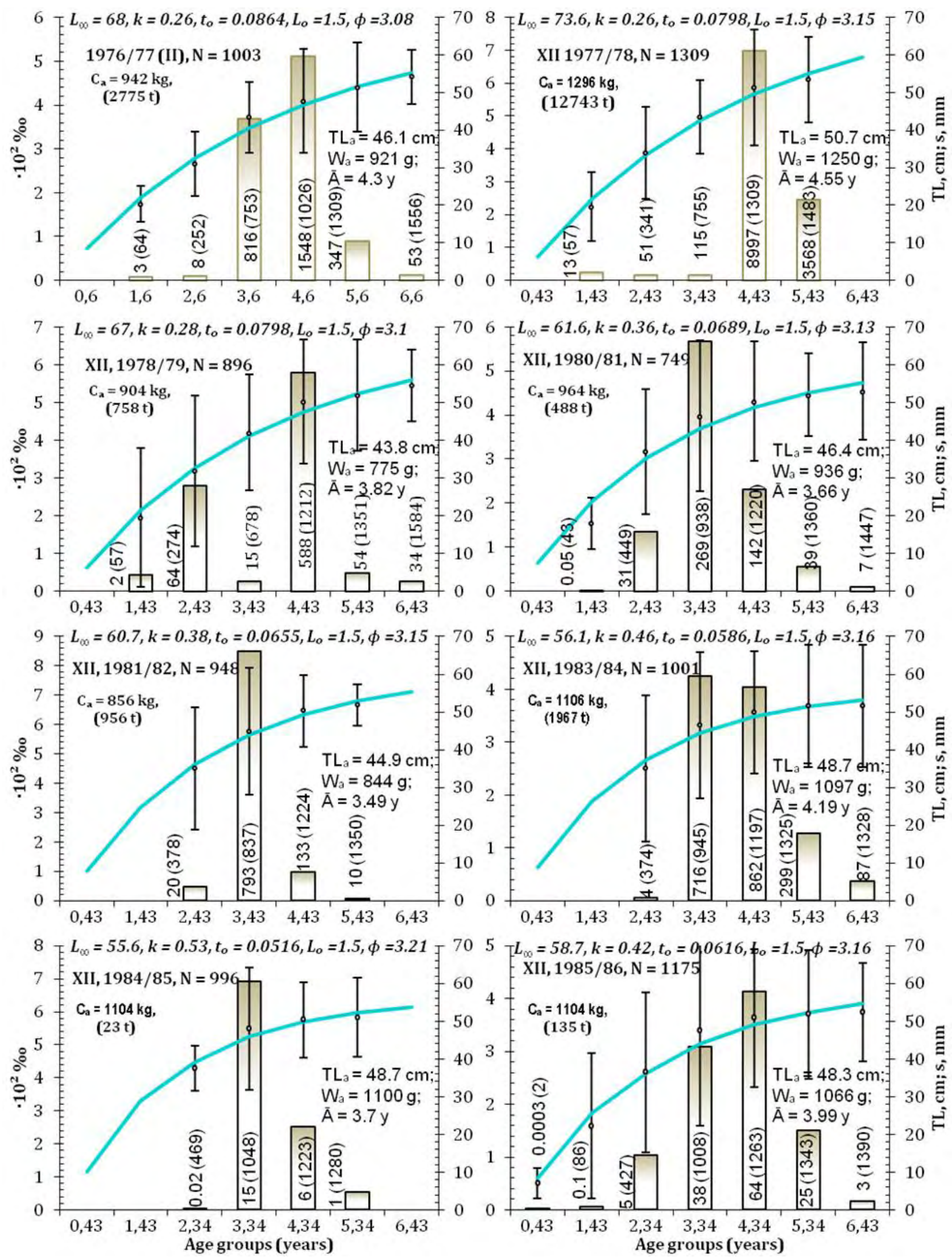

Fig. 21 Age of South Georgia Icefish in 1976/1977-1985/1986 fishing seasons, near bars are catch (t) and body mass (g). 

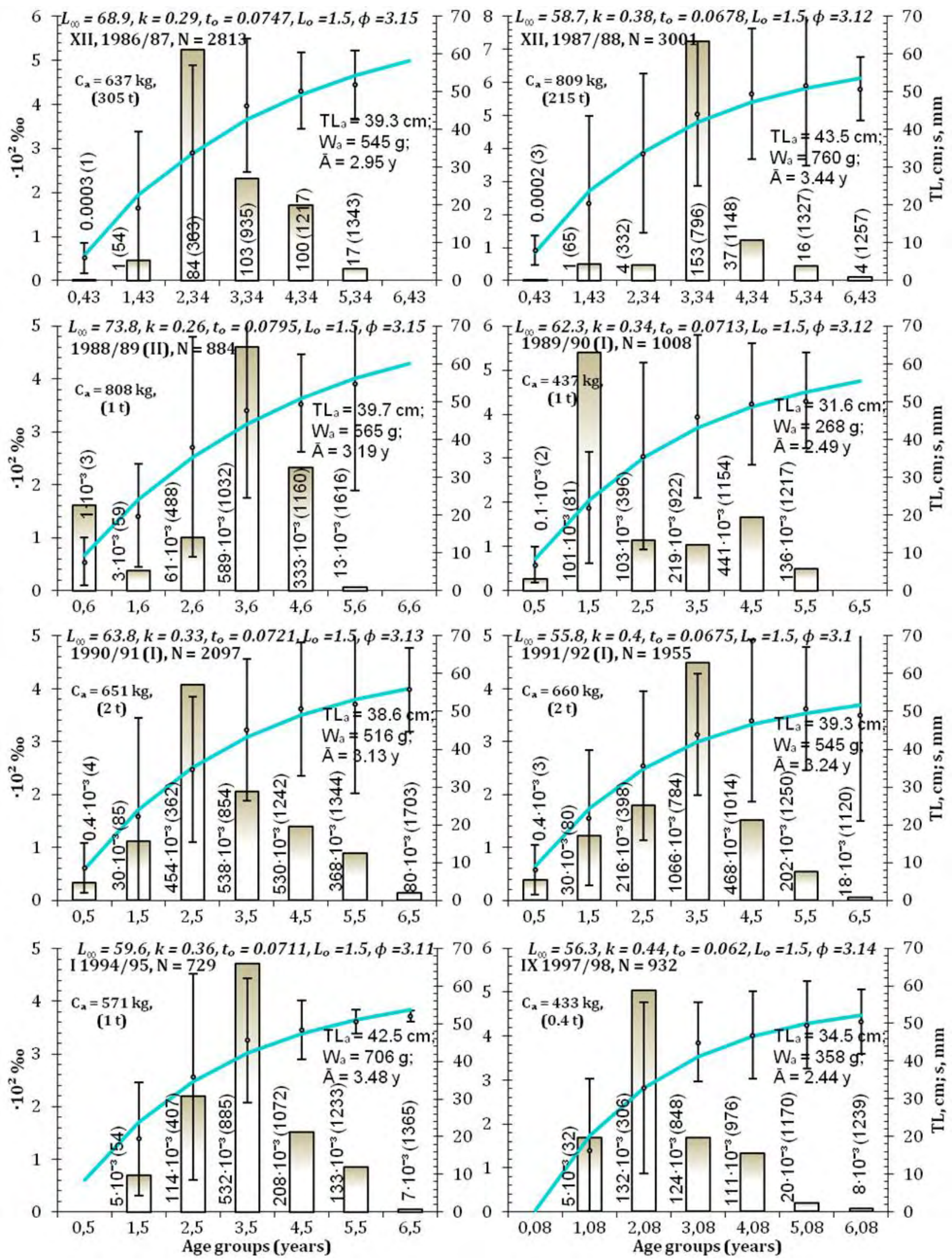

Fig. 22 Age of South Georgia Icefish in 1986/1987-1997/1998 fishing seasons. 

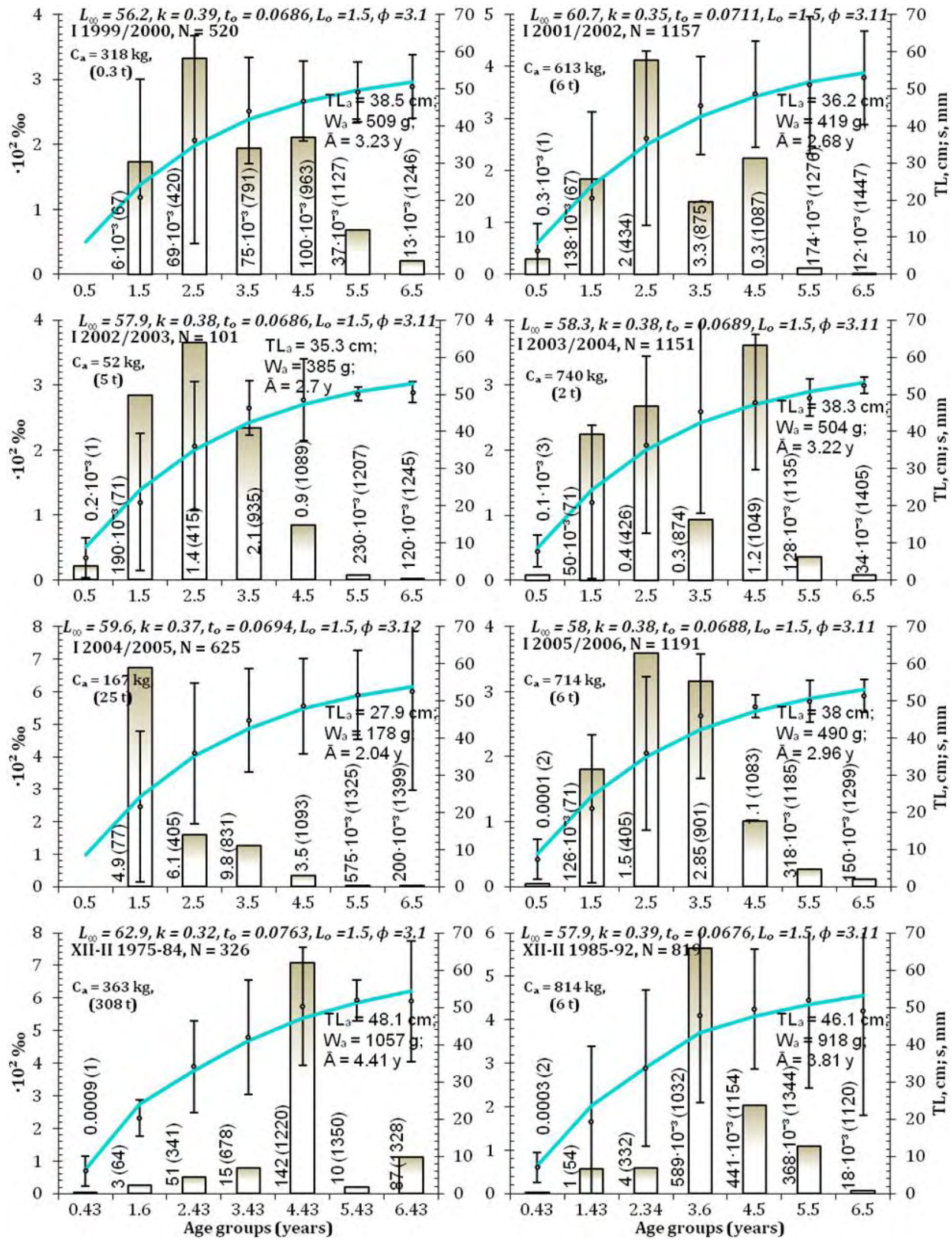

Fig. 23 Age of South Georgia Icefish in 1999/2000-2005/2006 fishing seasons, compare first cohort 1975-1984 with latter one. 

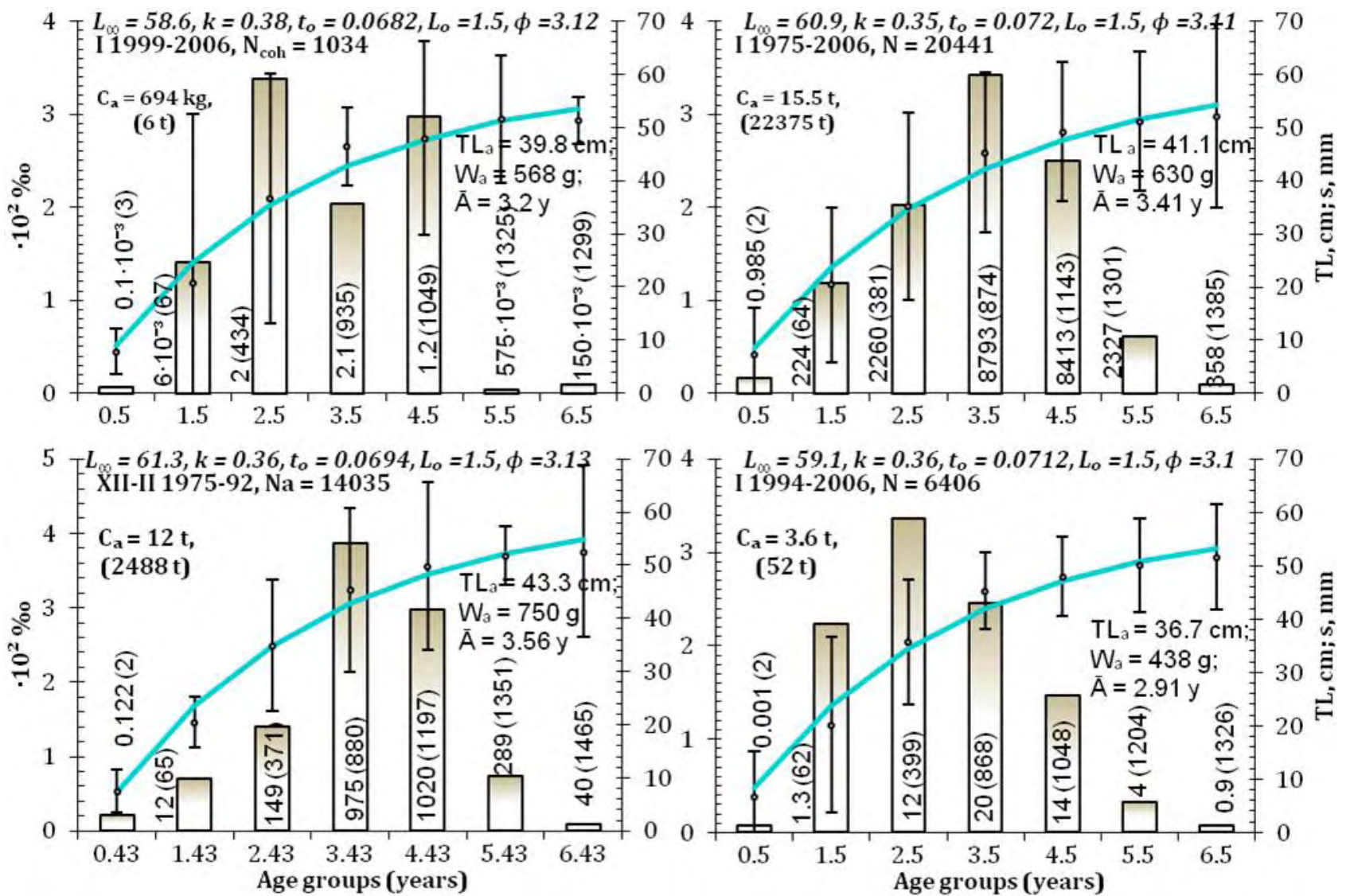

Fig. 24 Age structure of the last cohort and average growth rate obtained from 20,441 fish measured from 1975 to 2006.

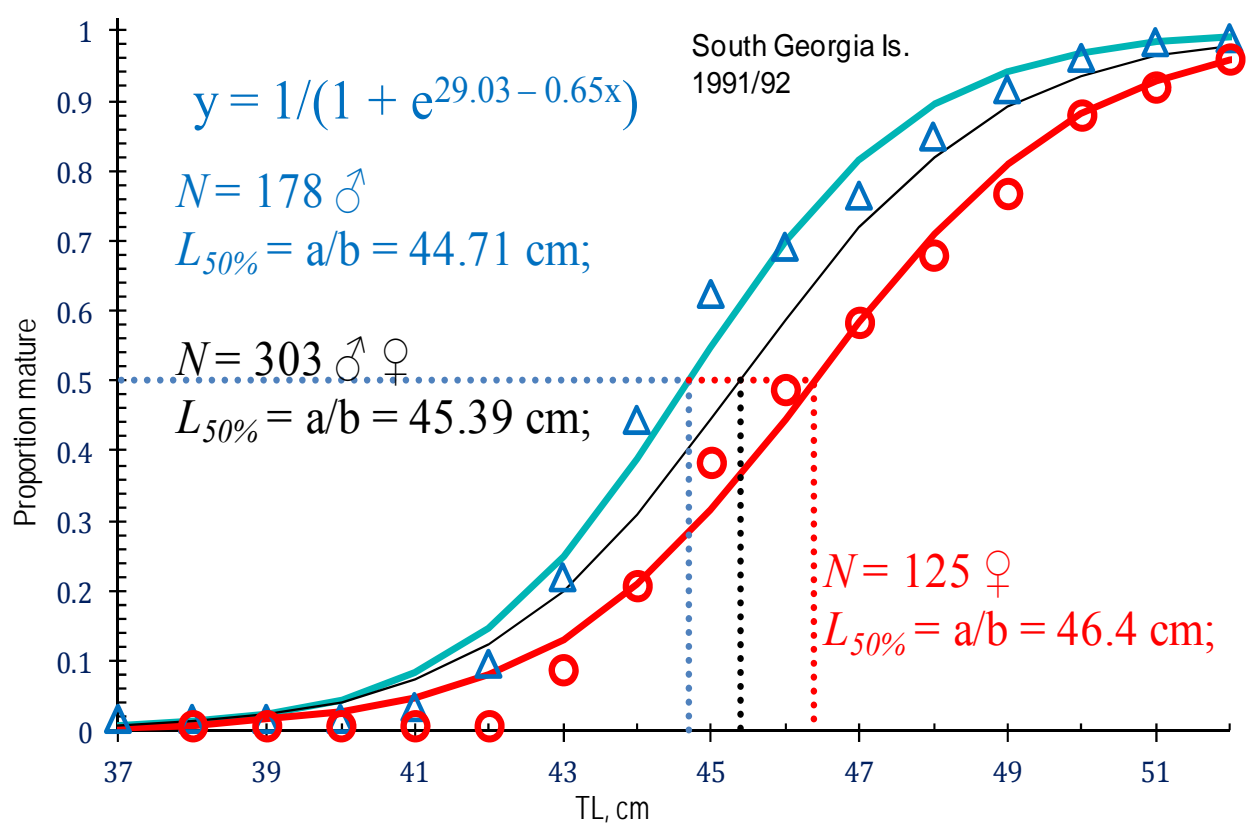

Fig. 25 Most fish about $45 \mathrm{~cm}$ (age over 3-4 years) spawn (first time) eggs of one generation between January and March. 


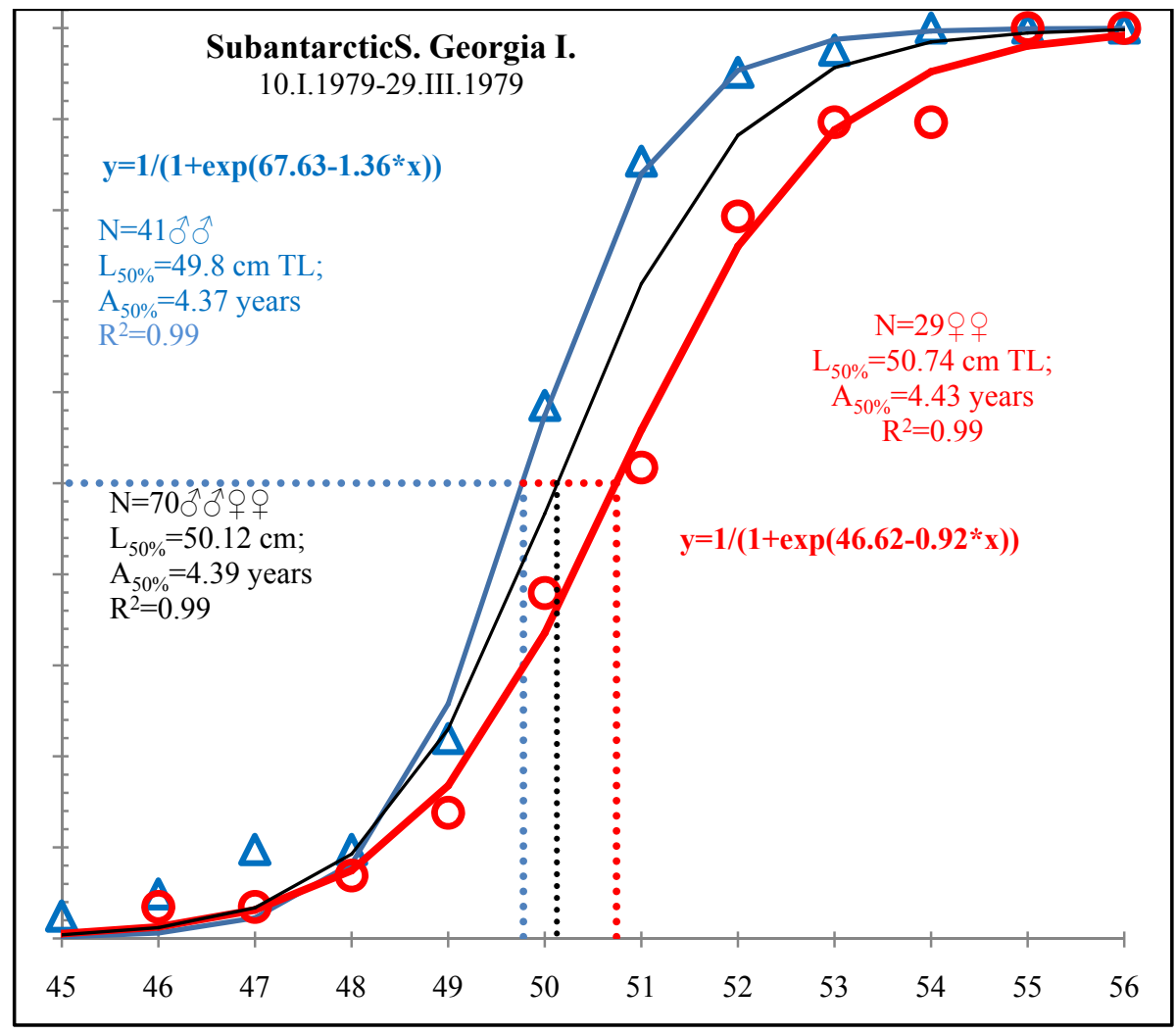

Fig. 2611 years earlier larger fish, about $50 \mathrm{~cm}$ (and older, age over 4 y) spawn first time eggs at South Georgia Island, it could be global warming effect that rise average water temperature from $1^{\circ} \mathrm{C}$ to $2.5^{\circ} \mathrm{C}$, in warmer water develop of fish go faster [21].

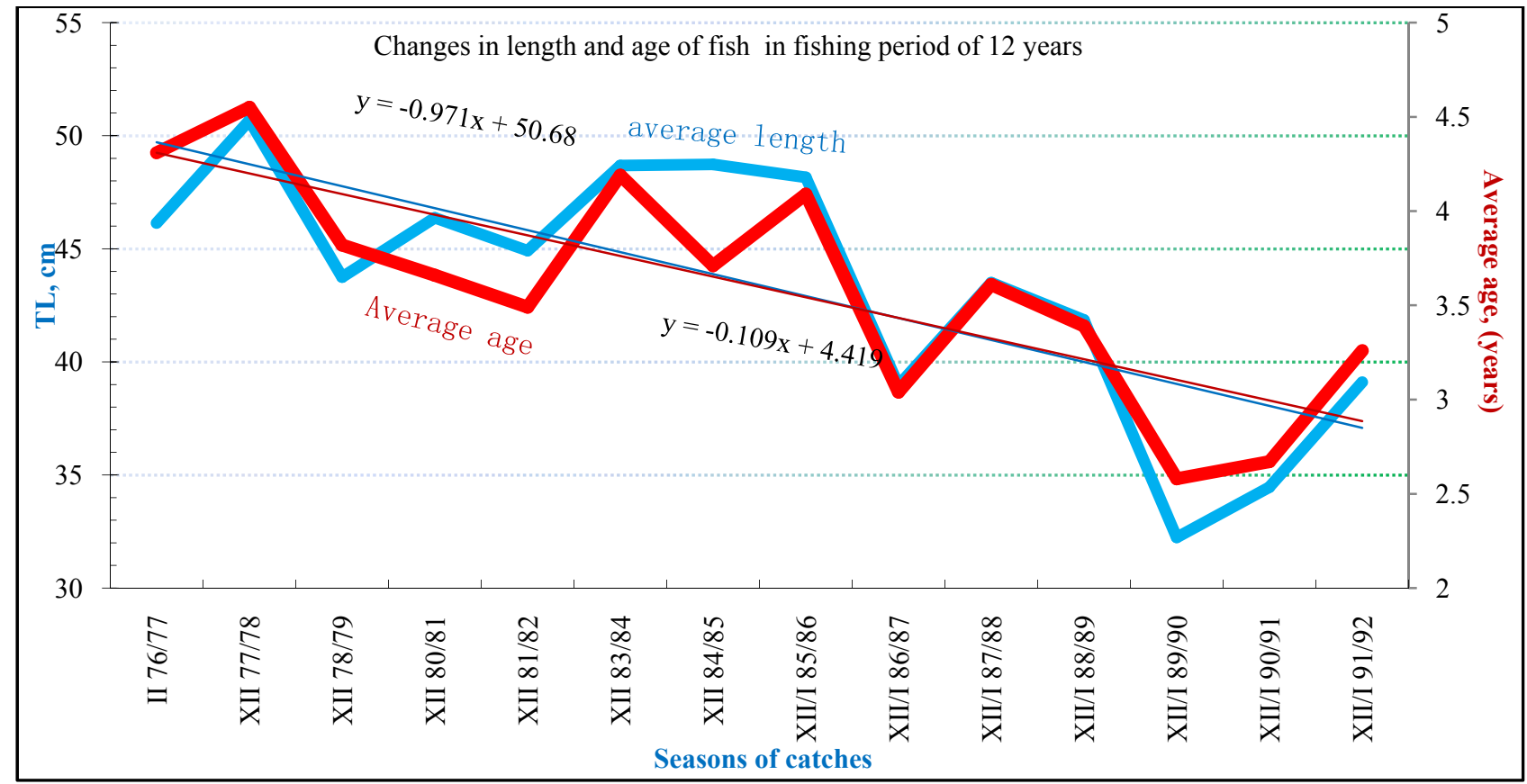

Fig. 27 Changes in average body length of over 14 seasons from research catches of Pseudochaenichthys georgianus of South Georgia Island. 


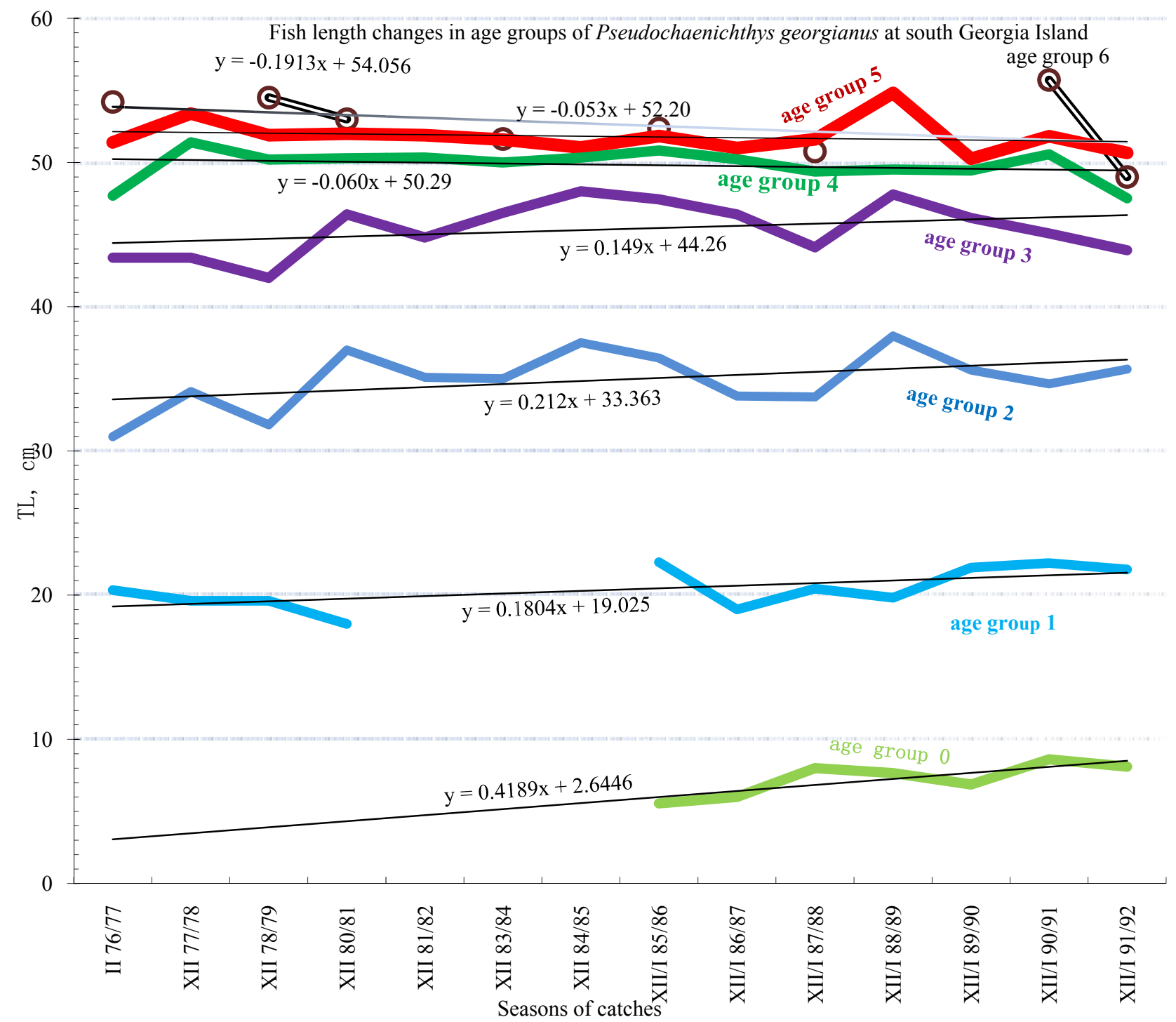

Fig. 28 Changes in average body length in age groups over 14 seasons of fishery on the shelf of South Georgia Island.

caught mostly in length two time smaller than Pseudochaenichthys georgianus and Chaenocephalus aceratus from fishing ground on north east sides (Figs. 2 and 3). Additionally, southern sides of Antarctic Island in that years were more ice covered with frequent danger iceberg tracks. The change of species distribution from high density to lack of them in north-eastern part of shelf were related conformed on adult large fish (Figs. 29 and 30). Adult Pseudochaenichthys georgianus were usually caught at north eastern shelf, the main fishing region, near Cumberland bay, where noted the large density of krill (Fig. 2). Catches consist almost all adults from South
Georgia Island that cumulate for spawning and for schools of krill. After large caches of them in 1988 and 1989, the region has not this species domination the next year (Fig. 30). There are two concurrent species became more important: Chaenocephalus aceratus and Gobionotothen gibberifrons. Those species in case of large number of adult Pseudochaenichthys georgianus have to migrate to west, where there is less food. This is adaptation of fish behavior to balance of cost and profit [46]. It is better to migrate to region with less food of krill than stay in the north with larger availability of food but under large risk to be eaten by Pseudochaenichthys 


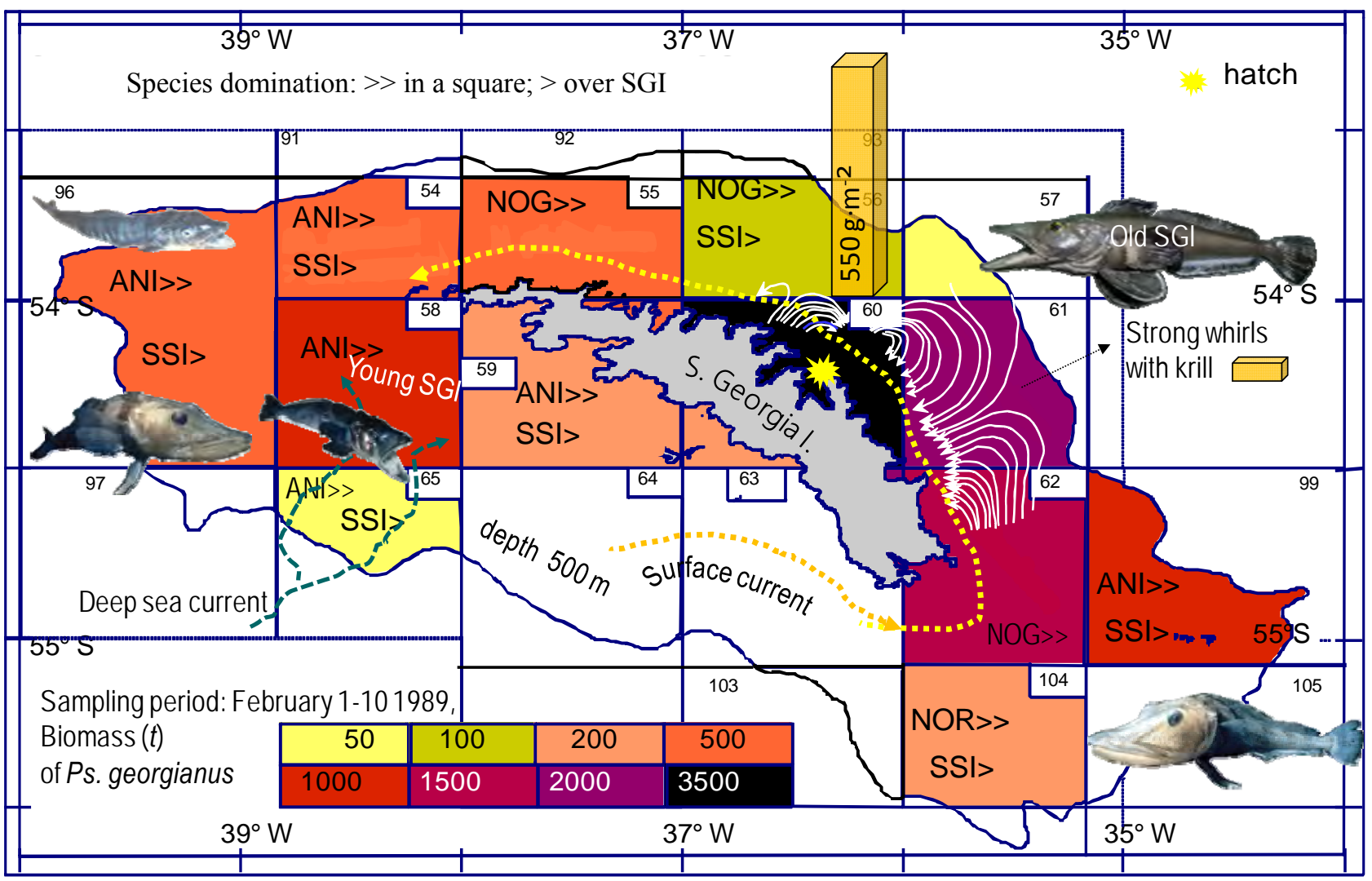

Fig. 29 Domination adult Pseudochaenichthys georgianus in interspecies interaction at north-east shelf of South Georgia Island, where strong whirls cumulate krill, bottom species Chaenocephalus aceratus live in deep sea current on western shelf of island together with young Pseudochaenichthys georgianus.

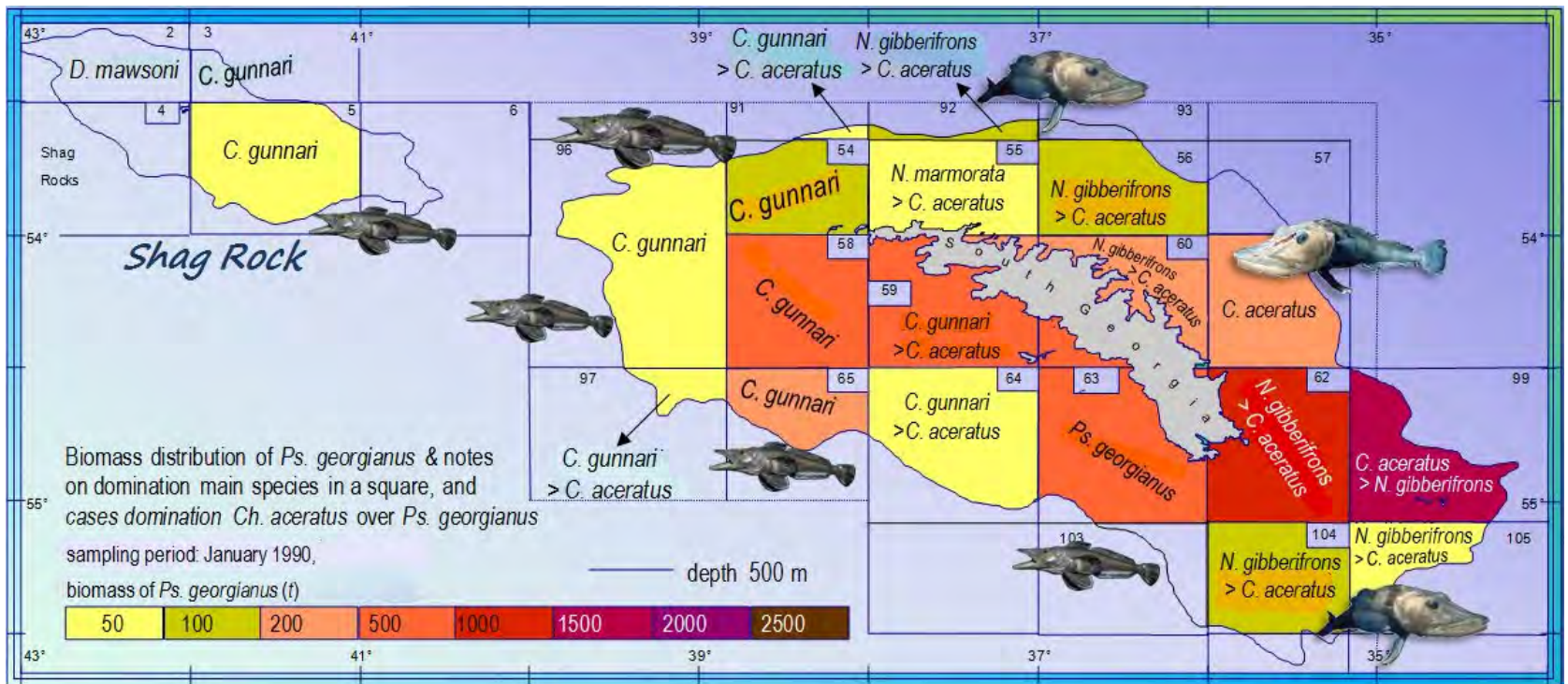

Fig. 30 After large catches of adult Pseudochaenichthys georgianus in 1988/1989, species loose domination on north-east shelf, the remain age group I of small Pseudochaenichthys georgianus live on the west in deeper water, it migrates even farther west into the peripheral habitat at rocks of Shag Rock, probably under high press of predators (lack of adults feeding on concurrent fish) they migrate there. 


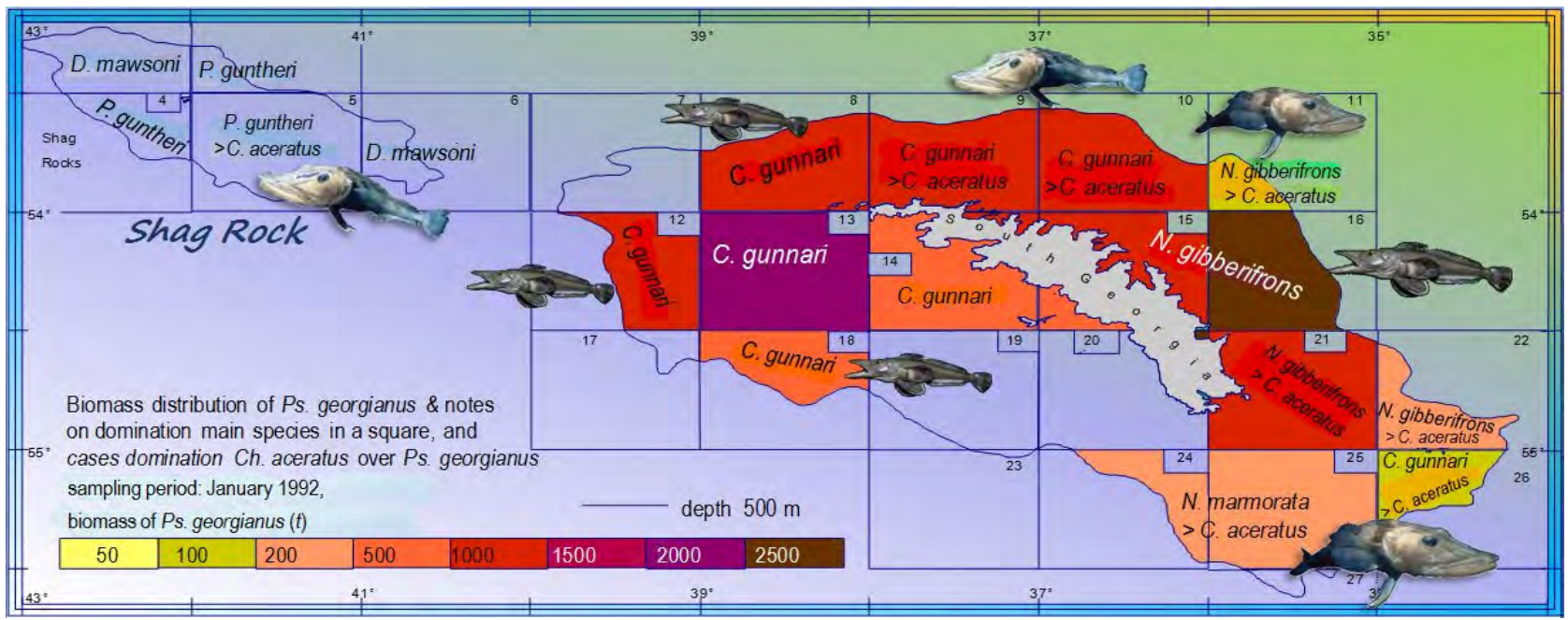

Fig. 31 Even it was 3 years after large catch of Pseudochaenichthys georgianus, adult do not restore their numbers to be a dominant on the szelf, in 1989-1990 age group of I of Pseudochaenichthys georgianus, now as 3 age group of large mature fish is cumulate in north-east part of the shelf in a warmer area of larger current turbulences accumulating krill in the northeast, this season Pseudochaenichthys georgianus is large, so Chaenocephalus aceratus is maintained in surrounding parts of shelf.

georgianus. Juveniles Pseudochaenichthys georgianus swim in deeper and weak currents in the western part of Island, after food, larvae of krill swimming on larger depth. The region as well for adults is not for juveniles, there are strong surface currents that disperse fish larvae out from the shelf. Once species was over caught, it loose its habitat, because it was overtaken by concurrents Gobionotothen gibberifrons and Chaenocephalus aceratus. Because of that, it is difficult to restore its stock on the shelf already overhelm by new species set with dominants: Chaenocephalus aceratus and Gobionotothen gibberifrons.

\subsection{Growth Parameters and Biology Size Dependend}

From age structures, the von Bertalanffy growth parameters were estimated; $L_{\infty}=62.9, \mathrm{k}=0.32, t_{0}=$ 0.0763, $L_{0}=1.5, \varphi=3.1$ for cohort living in period of high catches from December to February 1975-1984, and $\mathrm{L}_{\infty}=57.9, \mathrm{k}=0.39, t_{0}=0.0676, L_{0}=1.5, \varphi=3.11$ for cohort living in period of low catches from December to February 1985-1992. The parameter $t_{0}$ was derived from know length of hatching larvae $L_{0}=$ $1.5 \mathrm{~cm}$ and obtained value $365 \times 0.07=25$ days is acceptable for age at hatching in similar numbers of daily increments discovered from otolith centre to hatching mark. In the age structure (Figs. 21 and 22), age normal modes connected in subsequent years, there are over a dozen estimates of yearly growth rate for first six years (Figs. 21 and 22, Table 7). For postlarvae and first age group, yearly growth in average is similar, which is about $14 \mathrm{~cm} \cdot \mathrm{y}^{-1}$. And farther, it decreased to $11 \mathrm{~cm}$ per year for second age group, $5 \mathrm{~cm}, 2 \mathrm{~cm}$ and less than $1 \mathrm{~cm}$ for third, fourth and fifth age group respectively. Fitting equation von Bertalanffy to that averages, the growth parameters were estimated, $L_{\infty}=61.29, \mathrm{k}=0.357, t_{0}=0.0694, L_{0}$ $=1.5, \varphi=3.13$. In this method, it is possible to discover negative body shortening length when bone and mass desorption are able to reduce weight and survive the desert and fame periods.

Body length at $50 \%$ sexual maturity for both sexes was about $45 \mathrm{~cm}$ at age above 3 years, for male was $44.7 \mathrm{~cm} \mathrm{TL}$, for female was $46.4 \mathrm{~cm} \mathrm{TL}$ (Fig. 25 and 26). Mature Pseudochaenichthys georgianus, were more often in eastern part of shelf, while juveniles at western. For the stock estimation, the Total Length (TL) $(\mathrm{cm})$ to Mass (M) (g) relationships are given by the average equation: $M=0.0058 \cdot T L^{3.1441}, \mathrm{R}^{2}=0.9668$. At South Georgia Island, species has body more elongated indicated by lower allometric parameter (Figs. 32 and 33). For biomass estimation, the parameters for all 
Table 7 Estimates of average length at age and the yearly growth rate for first six years of life, shaded cells, example of cohorts.

\begin{tabular}{|c|c|c|c|c|c|c|c|c|c|c|c|c|c|}
\hline Season & 0 & & I & & II & & III & & IV & & $\mathrm{V}$ & & VI \\
\hline & $\mathrm{TL}$ & $d \mathrm{TL} \cdot \mathrm{y}^{-1}$ & $\mathrm{TL}$ & $+y^{-1}$ & $\mathrm{TL}$ & $+\mathrm{y}^{-1}$ & $\mathrm{TL}$ & $+y^{-1}$ & $\mathrm{TL}$ & $+y^{-1}$ & $\mathrm{TL}$ & $+y^{-1}$ & $\mathrm{TL}$ \\
\hline $1976 / 1977$ & & & 20.34 & 13.66 & 30.98 & 12.42 & 43.38 & 8.02 & 47.7 & 5.7 & 51.4 & & 54.2 \\
\hline $1977 / 1978$ & & & 19.6 & 12.2 & 34 & 8 & 43.4 & 6.8 & 51.4 & 0.5 & 53.4 & 1.1 & \\
\hline $1978 / 1979$ & & & 19.6 & 17.4 & 31.8 & 14.6 & 42 & 8.3 & 50.2 & 1.8 & 51.9 & 1.1 & 54.5 \\
\hline $1980 / 1981$ & & & 18 & 17.09 & 37 & 7.8 & 46.4 & 3.95 & 50.3 & 1.59 & 52 & & 53 \\
\hline $1981 / 1982$ & & & & & 35.09 & 11.41 & 44.8 & 5.2 & 50.35 & 1.24 & 51.89 & -0.26 & \\
\hline $1983 / 1984$ & & & & & 35 & 13 & 46.5 & 3.84 & 50 & 1.04 & 51.59 & & 51.63 \\
\hline $1984 / 1985$ & & & & & 37.5 & 9.94 & 48 & 2.83 & 50.34 & 1.46 & 51.04 & 1.31 & \\
\hline $1985 / 1986$ & 7 & 12.29 & 22.29 & 11.46 & 36.44 & 9.92 & 47.44 & 2.815 & 50.83 & 0.975 & 51.8 & & 52.35 \\
\hline $1986 / 1987$ & 6 & 14.44 & 19.29 & 14.45 & 33.75 & 10.37 & 46.36 & 3.01 & 50.255 & 1.355 & 51.805 & -1.045 & \\
\hline $1987 / 1988$ & 8 & 11.82 & 20.44 & 17.53 & 33.74 & 14.04 & 44.12 & 5.4 & 49.37 & 5.46 & 51.61 & & 50.76 \\
\hline 1988/1989 & 7.65 & 14.25 & 19.82 & 15.78 & 37.97 & 8.18 & 47.78 & 1.66 & 49.52 & 0.74 & 54.83 & & \\
\hline $1989 / 1990$ & 6.86 & 15.36 & 21.9 & 12.74 & 35.6 & 9.48 & 46.15 & 4.42 & 49.44 & 2.38 & 50.26 & 5.46 & \\
\hline $1990 / 1991$ & 8.61 & 13.16 & 22.22 & 13.45 & 34.64 & 9.27 & 45.08 & 2.44 & 50.57 & 0.1 & 51.82 & -2.82 & 55.72 \\
\hline 1991/1992 & 8.1 & 11.19 & 21.77 & 11.97 & 35.67 & 12.11 & 43.91 & 5.53 & 47.52 & 4.3 & 50.67 & -1.67 & 49 \\
\hline $1994 / 1995$ & & & 19.35 & 13.55 & 35.90 & 9.09 & 45.58 & 1.39 & 48.34 & 1.32 & 50.46 & 0.07 & 52.06 \\
\hline 1997/1998 & & & 16.48 & 19.77 & 32.90 & 11.14 & 44.99 & 1.79 & 46.97 & 2.12 & 49.66 & 0.96 & 50.53 \\
\hline $1999 / 2000$ & & & 20.66 & 15.97 & 36.24 & 9.18 & 44.04 & 4.51 & 46.78 & 4.22 & 49.09 & 3.91 & 50.62 \\
\hline $2001 / 2002$ & 6.35 & 14.65 & 20.61 & 15.51 & 36.63 & 9.72 & 45.42 & 3.15 & 48.55 & 1.58 & 51.00 & -0.39 & 53.00 \\
\hline $2002 / 2003$ & 6.00 & 15.05 & 21.00 & 15.42 & 36.12 & 9.28 & 46.35 & 1.66 & 48.57 & 0.62 & 50.13 & 2.40 & 50.61 \\
\hline $2003 / 2004$ & 7.80 & 13.73 & 21.05 & 14.81 & 36.42 & 8.29 & 45.40 & 3.23 & 48.02 & 3.57 & 49.19 & 3.26 & 52.53 \\
\hline $2004 / 2005$ & & & 21.53 & 14.33 & 35.86 & 9.97 & 44.71 & 3.79 & 48.63 & 1.23 & 51.59 & -0.31 & 52.45 \\
\hline $2005 / 2006$ & 7.33 & 13.33 & 20.99 & 15.64 & 35.87 & 10.49 & 45.83 & 2.19 & 48.50 & 3.09 & 49.86 & 1.43 & 51.28 \\
\hline $1976-2006$ & 7.20 & 13.60 & 20.40 & 14.90 & 35.2 & 10.3 & 45.3 & 3.9 & 49.2 & 2.1 & 51.2 & 0.90 & 52.10 \\
\hline s & 0.88 & 1.36 & 1.46 & 2.15 & 1.77 & 1.9 & 1.51 & 1.98 & 1.31 & 1.6 & 1.32 & 2.12 & 1.72 \\
\hline $\mathrm{N}$ & 345 & & 2423 & & 4124 & & 7005 & & 5108 & & 1256 & & 180 \\
\hline 1976-1992 & 7.5 & 13.2 & 20.5 & 14.3 & 34.9 & 10.8 & 45.4 & 4.6 & 49.8 & 2 & 51.9 & 0.4 & 52.6 \\
\hline s & 0.89 & 1.53 & 1.4 & 2.27 & 2.01 & 2.22 & 1.84 & 2.06 & 1.09 & 1.8 & 1.12 & 2.52 & 2.18 \\
\hline $\mathrm{N}$ & 295 & & 990 & & 1973 & & 5427 & & 4170 & & 1047 & & 133 \\
\hline $1994-2006$ & 6.9 & 14.2 & 20.2 & 15.6 & 35.7 & 9.6 & 45.3 & 2.7 & 48 & 2.2 & 50.1 & 1.4 & 51.6 \\
\hline $\mathrm{s}$ & 0.84 & 0.79 & 1.64 & 1.85 & 1.18 & 0.89 & 0.71 & 1.12 & 0.75 & 1.27 & 0.87 & 1.64 & 0.99 \\
\hline $\mathrm{N}$ & 50 & & 1433 & & 2151 & & 1578 & & 938 & & 209 & & 47 \\
\hline 1999-2006 & 7.80 & 12.86 & 20.66 & 15.97 & 36.63 & 9.72 & 46.35 & 1.66 & 48.02 & 3.57 & 51.59 & -0.31 & 51.28 \\
\hline
\end{tabular}

South Georgia Island were averaged but there are different oceanographic regions with differences in species set and in individual sizes (juveniles at western adult at eastern part), as it was discovered among Antarctic Islands. Different conditions have influence on growth of fish and on their ages depended preferences as it take effect in geographical and vertical differences in length and age distributions. The differences could be started even from hatching. At South Georgia Island, there were post larvae in December 1988/1989 and latter. Their hatching otolith have surfaces in range: $2.99 \times$ $10^{-2} / 4.6 \times 10^{-2} \mathrm{~mm}$. The smaller larvae caught earlier have smaller hatching otolith indicate shorter development in the egg laid in wormer region or time. It could be sex depended, because among younger fish, males were noted larger. In opposite, it was among older fish. 
Table 8 Males were found to weight at length more than females that are more elongated: $\boldsymbol{b}_{\text {males }}>\boldsymbol{b}_{\text {females}}$, at Elephant Island large females dominate over smaller males, in the south direction body mass increase.

\begin{tabular}{|c|c|c|c|c|c|c|c|c|c|c|c|c|c|c|c|}
\hline \multirow{2}{*}{$\begin{array}{l}\text { Region } \\
\mathrm{M}, \mathrm{g}=\mathrm{a} \cdot \mathrm{TL}^{\mathrm{b}}\end{array}$} & \multicolumn{5}{|c|}{ Males and females } & \multicolumn{5}{|c|}{ Females } & \multicolumn{5}{|c|}{ Males } \\
\hline & $\mathrm{TL}, \mathrm{cm}$ & $\mathrm{b}$ & $\mathrm{a}$ & $\mathrm{R}^{2}$ & $\mathrm{~N}$ & $\mathrm{TL}, \mathrm{cm} \mathrm{b}$ & $\mathrm{b}$ & A & $\mathrm{R}^{2}$ & $\mathrm{~N}$ & TL, $\mathrm{cm} \mathrm{l}$ & $\mathrm{b}$ & $\mathrm{a}$ & $\mathrm{R}^{2}$ & $\mathrm{~N}$ \\
\hline Atlantic Section & & & & 77 & 779 & 6 & 3.0798 & 74 & 0.965 & 393 & 19 & 3.208 & 45 & 0.969 & 386 \\
\hline & & & & 83 & 176 & & 2 & 38 & 0.982 & 82 & & 3.022 & & 0.50 & \\
\hline & & & & 4 & 342 & 6 & & 1 & 41 & 188 & 4 & 85 & 94 & 0.736 & 6154 \\
\hline S.Sh & $/ 53$ & & & 55 & 261 & 533 & 3.439 & $0 .($ & 0.944 & 123 & 26 & 3.48 & 0.0 & 0.961 & 138 \\
\hline S. S & $27 / 53$ & 796 & 11 & 954 & 202 & $28 / 53$ & 3.68 & 0.0008 & 0.949 & 99 & $27 / 52$ & 3.519 & 0.0014 & 0.956 & 103 \\
\hline K.Ge & $31 / 53$ & 6088 & 0.0010 & 0.934 & 67 & $40 / 53$ & 3.798 & 0.0005 & 0.894 & 34 & $31 / 52$ & 3.5505 & 0.0013 & 0.955 & 33 \\
\hline Elep & $40 / 52$ & & & 965 & 17 & $40 / 51$ & 3.7294 & 0 . & 0.972 & 11 & $32 / 52$ & 3.1 & 0. & 974 & \\
\hline .0 & $31 / 53$ & & & 947 & 50 & 40 & 3.992 & 0.0002 & 0.892 & 23 & & 3.859 & 0.0004 & 0.975 & 27 \\
\hline ece & $26 / 52$ & & 0018 & 957 & 194 & $28 / 52$ & 3.4074 & 0.0022 & 0.951 & 89 & & 3.4607 & 0.0017 & 0.959 & 105 \\
\hline Dece & $27 / 52$ & 844 & 0.0011 & 0.958 & 135 & $28 / 50$ & 3.6904 & 0.0007 & 0.963 & 65 & 2 & 3.505 & 0.0015 & 0.954 & 70 \\
\hline Palmer Archipelago & $26 / 41$ & 3.1664 & 0.005 & 0.958 & 59 & $30 / 52$ & 2.932 & 0.0123 & 0.956 & 24 & $26 / 50$ & 3.295 & 0.0031 & 0.964 & 35 \\
\hline
\end{tabular}

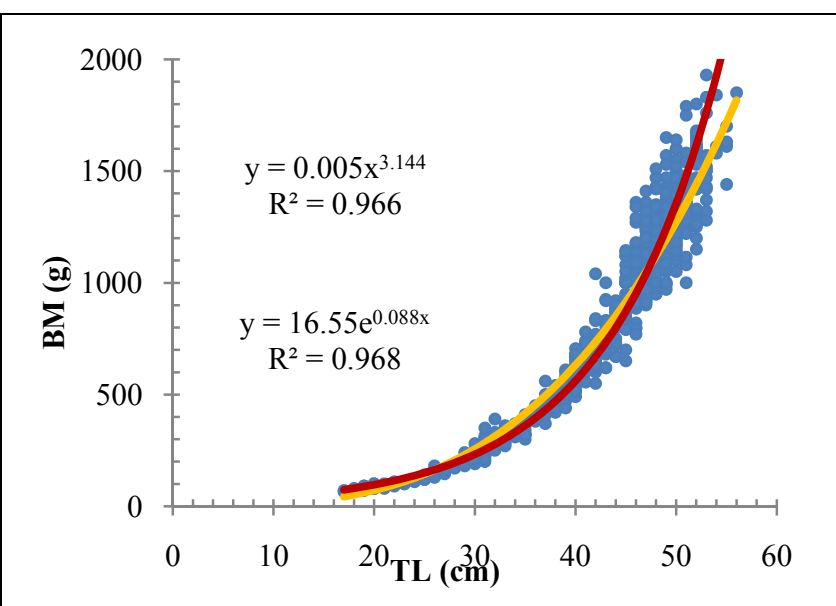

Fig. 32 Pseudochaenichthys georgianus up to $30 \mathrm{~cm}$ TL, more increase in length, next proportionally to mass until reach 47-49 $\mathrm{cm}$ TL and over $50 \mathrm{~cm}$ TL, growth of length decrease but mass increase in power.

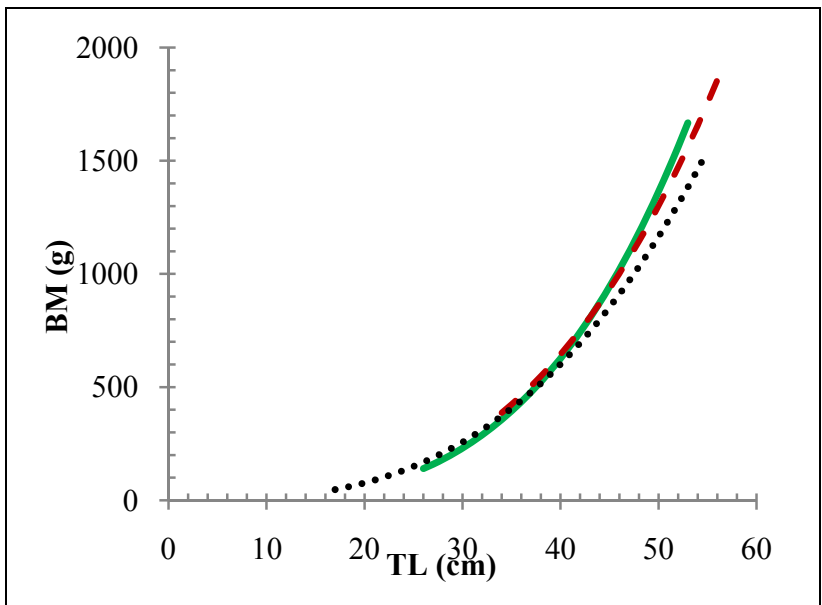

Fig. 33 Pseudochaenichthys georgianus at South Georgia Island (dotted line) is more elongated and has smaller condition parameter: $\mathrm{CP}=\mathrm{BM} \cdot 100 / \mathrm{TL}^{3}=0.95$ (in the Antarctic zone $\mathrm{CP}=\mathbf{1 . 0 3}$ South Orkney breaking line, South Shetland solid line).

Table 9 Effort data $\left(\times 10^{3}\right.$ trawling hours), $f_{y}$-Osteichthyes, Nototheniidae and Champsocephalus gunnari, $f_{y}$-Champsocephalus gunnari, for estimation natural mortality, $M$ of Pseudochaenichthys georgianus from South Georgia Island, $T L-$ average length of all fish in the catch (Figs. 17, 21 and 24), total mortality: $Z=k \cdot\left(L_{\infty}-T L\right)\left(T L-L_{C}\right)^{-1}, L_{\infty}=60.6 \mathrm{~cm}, k=0.349$ per year, $L_{C}, 50 \%$ retention length, $L_{C}=38 \mathrm{~cm}\left(1976-1988\right.$ large fish from north east area (Fig. 17)), $L_{C}=18.94 \mathrm{~cm}(1987-2006$ all length fish from all shelf of island), $L_{C}=7.2 \mathrm{~cm}(2004 / 2005$ small fish numerous in western side of island) [43].

\begin{tabular}{|c|c|c|c|c|c|c|c|c|c|c|c|c|c|c|c|c|}
\hline Year & $f_{y}$ & $f_{y}^{\prime}$ & $T L$ & $Z$ & Year & $f_{y}$ & $f_{y}^{\prime}$ & $T L$ & $Z$ & Year & $f_{y}$ & $f_{y}^{\prime}$ & $T L$ & $Z$ & Year & $f_{y}$ \\
\hline $1976 / 1977$ & 0.57 & 2.4 & 46.14 & 0.62 & $1986 / 1987$ & 1.39 & 39.7 & 39.27 & & $1996 / 1997$ & & & & & $2006 / 2007$ & 0.18 \\
\hline $1977 / 1978$ & 1.41 & 21.6 & 50.68 & 0.27 & $1987 / 1988$ & 0.28 & 26.7 & 43.49 & $0.24-1$ & $1997 / 1998$ & & & 34.53 & & $2007 / 2008$ & 0.11 \\
\hline $1978 / 1979$ & 1.87 & 11.6 & 43.75 & 1.02 & $1988 / 1989$ & 0.04 & 5.78 & 39.72 & 0.35 & $1998 / 1999$ & & & & & $2008 / 2009$ & 0.08 \\
\hline $1979 / 1980$ & 1.49 & 13.2 & & & $1989 / 1990$ & 1.00 & 1.96 & 31.58 & 0.80 & $1999 / 2000$ & 0.40 & 0.88 & 38.46 & 0.40 & $2009 / 2010$ & 0.04 \\
\hline $1980 / 1981$ & 1.46 & 7.2 & 46.37 & 0.59 & $1990 / 1991$ & 0.13 & 0.18 & 38.61 & 0.39 & $2000 / 2001$ & 0.11 & 0.70 & & & $2010 / 2011$ & 0.02 \\
\hline $1981 / 1982$ & 2.43 & 10.5 & 44.92 & 0.79 & $1991 / 1992$ & & & 39.72 & 0.35 & $2001 / 2002$ & 0.67 & 2.46 & 36.24 & 0.49 & $2011 / 2012$ & 0.04 \\
\hline $1982 / 1983$ & 8.00 & 45.5 & & & $1992 / 1993$ & & & & & $2002 / 2003$ & 0.36 & 0.69 & 35.29 & 0.54 & $2012 / 2013$ & 0.07 \\
\hline $1983 / 1984$ & 1.00 & 31.8 & 48.68 & 0.39 & $1993 / 1994$ & 0.01 & 0.02 & & & $2003 / 2004$ & 0.67 & 1.10 & 38.34 & 0.40 & $2013 / 2014$ & 0.10 \\
\hline $1984 / 1985$ & 0.64 & 10.4 & 48.73 & 0.39 & $1994 / 1995$ & 0.09 & 0.09 & 42.52 & 0.27 & $2004 / 05$ & 0.21 & 1.55 & 27.86 & $6-1.3$ & $2014 / 15$ & \\
\hline $1985 / 1986$ & 0.84 & 14.4 & 48.26 & 0.42 & $1995 / 1996$ & & & & & $2005 / 06$ & 0.48 & 2.23 & 38.02 & 0.41 & $2015 / 16$ & \\
\hline
\end{tabular}




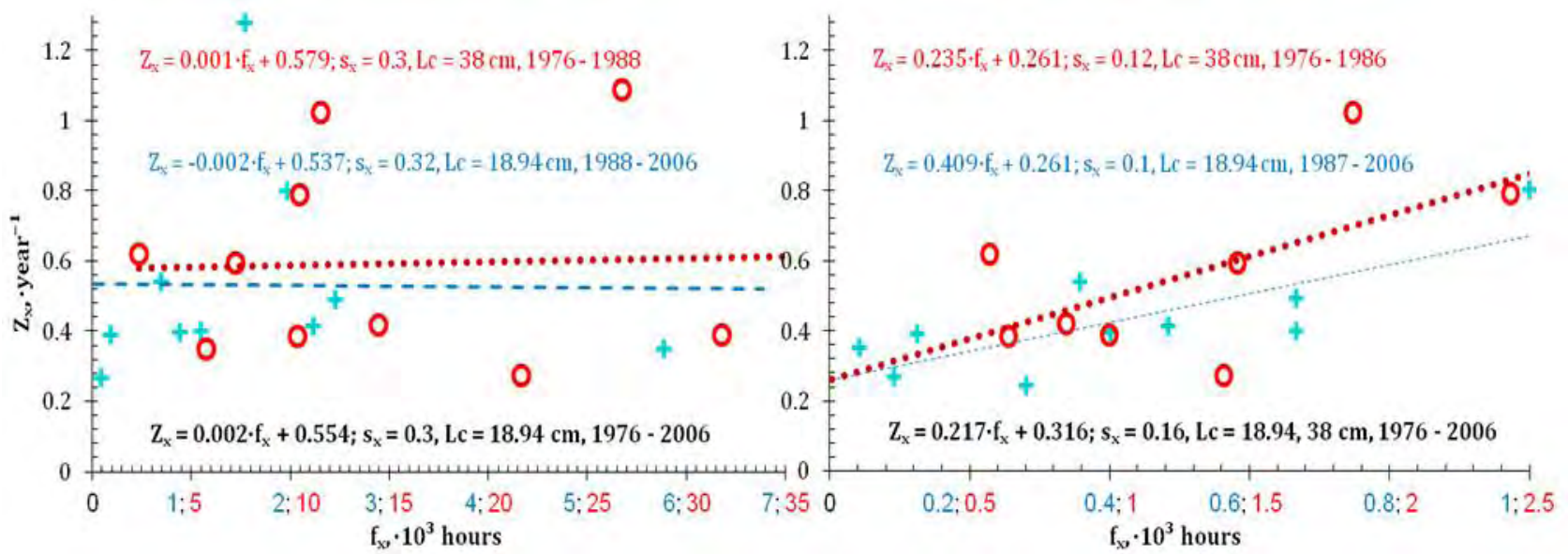

Fig. 34 Relation of total mortality, $Z$ from effort, $f$ that give estimation of natural mortality, $M$ and catchability coefficient, q. First plot estimate $\mathrm{M}=\mathbf{0 . 5 8}$ (1976-1988) and 0.54 (1988-2006) from effort on all fish during which Pseudochaenichthys georgianus could be in bycatch, second one estimate $M=0.26$ per year on expert chosen effort on similar species, mackerel icefish with positive catches of Pseudochaenichthys georgianus.

To estimate the number, fish survive natural mortality was estimated from regression on dependence of total mortality, $Z_{y}$ on an effort $f_{y}: Z_{y}=q \cdot f_{y}+M$. All effort done to catch fish gives result, $M=0.55$ (Fig. 34), that is similar to value obtained with Alagaraja method $\mathrm{M}=$ 0.58 per year (life span $8 \mathrm{y}$ ) and is similar to estimates for similar species Champsocephalus gunnari: $\mathrm{M}=0.5$ [6]. The expert approach of effort choosing give the estimate of mortality $\mathrm{M}=0.31$ per year, which is similar to value obtained with Rigkhter and Efanov's formula linked to age of massive maturation $\mathrm{A}_{50 \%}=$ 4.5 year (Fig. 26): $\mathrm{M}=1.521 \cdot\left(\mathrm{A}_{50 \%}{ }^{0.72}\right)^{-1}-0.155=0.36$. Currently, temperature is higher by $0.9-2.3{ }^{\circ} \mathrm{C}$ because of global warming fish develop earlier and their natural mortality is increasing: $A_{50 \%}=4$ year, $M=0.4$ (Fig. 25) [21]. Since young live below $200 \mathrm{~m}$, where is not warm, their natural mortality will be lower [21].

Instead of above Pauly's formula, linked to water surface temperature give lover values of $M$ : $M=\mathrm{e}^{-0.0152-0.279 \ln L_{\infty}+0.6543 \ln K+0.463 \ln T}=$ 0.22 per year for older fish. Young living in deep colder water may have lover mortality. Since over long period of protection of Pseudochaenichthys georgianus, its species stock was not recovered, natural mortality probably reach higher level of in its range of variability.

Estimated the age composition data in the yearly catches of Pseudochaenichthys georgianus (spawning is once per year) give total mortality rate $\mathrm{Z}$ for each year of fishing as a slope of linearized catch curve equation with constant time intervals: $\ln C_{t, t+1 y}=$ $q-\mathrm{Z} \cdot \mathrm{t}$ (Figs. 35-38) [8, 44]. The result shows many large distant values suggest regular changes, whose average are not describe. Instead of steady change, mortality rate of Pseudochaenichthys georgianus is changing periodically around 1.5 per year with amplitude 0.5 and 0.14 of die proportion and replay in 8 years cycle, probably linked also with cycle of anomaly warm and cold years at South Georgia Island [21]. With die proportion of $Z=1.5$, per year percentage of survivals after 1 year are $100 \cdot e^{-1.5 \cdot 1}=$ $22.3 \%$ and after 2 years survivals will be $100 \cdot e^{-1.5 \cdot 2}=$ $5 \%$. Changing proportion of $\mathrm{Z}$ with amplitude 0.5 become $Z=2$, and survivals become mach less. After 1 year, survivals will be $100 \cdot e^{-2 \cdot 1}=14 \%$ and after 2 years will be $2 \%$. Almost 2 time more die. Taking into account fluctuation of $\mathrm{Z}$ two time more improve the stock assessment.

The oscillations of total mortality could be linked with oscillation of anomaly temperature. Anomaly cold season in 1981/1982 cause delayed and low primary production and less food, so increase mortality of all SG icefish (Figs. 37 and 38) [21]. Anomalously warmer season in 1985/1986 reduced 
amount of krill and lowered its availability for fish as a food, which cause increase of mortality of adult Pseudochaenichthys georgianus [21]. On the other side, warm season is more productive because of that decrease mortality of younger SG icefish, living below $200 \mathrm{~m}$, where warming temperature was not evident (Figs. 37 and 41) [21]. Mortality of mesozooplankton (fish larvae) embryonic development depend on temperature [21].

\subsection{Dependency of Abundance of SGI Icefish from Krill}

Strong dependence of fishes on krill is confirmed by the results of biological research of fish and krill carried on $\mathrm{r} / \mathrm{v}$ "Professor. Siedlecki" in the area of Scotia sea in 1988/1989 and 1978/1979. It showed that catching of adult fish Pseudochaenichthys georgianus were higher in areas where there were greater densities of larger krill (Figs. 39-45). Postlarvae lead an exclusively pelagic life deep at the shelf edge, between K. George and Elephant (Figs. 42 and 43) [45]. Krill juvenile stages developing from eggs laid at depth of 2,000 m migrate to surface far from the shore (Figs. 42-45). Juvenile Pseudochaenichthys georgianus were also the bycatch in the krill fishery [10].

Table 10 Linearized catch curve analysis based on age composition data, number caught per year by age group of South Georgia Icefish, $Z_{\text {All }}$-all fish, $Z$-old adults from warm surface water of north-east shelf (young fish were at deep cold waters in western-south shelf (Figs. 29 and 30).

\begin{tabular}{|c|c|c|c|c|c|c|c|c|c|c|c|c|}
\hline Year & 0.5 & 1.5 & 2.5 & 3.5 & 4.5 & 5.5 & 6.5 & $\mathrm{Z}$ & \pm & $\mathrm{Z}_{\mathrm{All}}$ & \pm & $\mathrm{F}$ \\
\hline $1976 / 1977\left(\times 10^{6}\right)$ & & $\underline{0.043}$ & 0.033 & 1.083 & 1.509 & 0.265 & 0.034 & 1.898 & 0.104 & 1.213 & 0.389 & 1.318 \\
\hline $1977 / 1978\left(\times 10^{6}\right)$ & & 0.224 & $\underline{0.149}$ & 0.152 & 6.873 & 2.406 & & 1.050 & 1.588 & 2.717 & 1.089 & 0.470 \\
\hline $1978 / 1979\left(\times 10^{6}\right)$ & & 0.040 & 0.235 & $\underline{0.022}$ & 0.485 & 0.040 & 0.022 & 1.558 & 0.616 & 1.558 & 0.616 & 0.978 \\
\hline $1980 / 1981\left(\times 10^{6}\right)$ & & 0.001 & 0.068 & 0.287 & $\underline{0.117}$ & 0.028 & 0.005 & 1.604 & 0.123 & 1.374 & 0.160 & 1.024 \\
\hline $1981 / 1982\left(\times 10^{6}\right)$ & & & 0.053 & 0.948 & 0.109 & $\underline{0.007}$ & & 2.448 & 0.184 & 1.794 & 0.611 & 1.868 \\
\hline $1983 / 1984\left(\times 10^{6}\right)$ & & & 0.011 & 0.758 & 0.720 & 0.226 & $\underline{0.065}$ & 1.201 & 0.027 & 0.852 & 0.228 & 0.621 \\
\hline $1984 / 1985\left(\times 10^{3}\right)$ & & & 0.049 & 14.419 & 5.228 & 1.150 & & 1.264 & 0.163 & 1.963 & 0.443 & 0.684 \\
\hline $1985 / 1986\left(\times 10^{3}\right)$ & $\underline{0.135}$ & 0.785 & 12.804 & 37.768 & 50.558 & 18.395 & 2.040 & 1.605 & 0.388 & 0.961 & 0.419 & 1.025 \\
\hline $1986 / 1987\left(\times 10^{6}\right)$ & 0.0003 & $\underline{0.023}$ & 0.252 & 0.111 & 0.082 & 0.012 & & 1.090 & 0.517 & 0.931 & 0.253 & 0.510 \\
\hline $1987 / 1988\left(\times 10^{6}\right)$ & 0.0001 & 0.013 & $\underline{0.013}$ & 0.193 & 0.032 & 0.012 & 0.003 & 1.171 & 0.123 & 1.302 & 0.127 & 0.591 \\
\hline $1988 / 1989\left(\times 10^{3}\right)$ & 0.333 & 0.051 & 0.125 & $\underline{0.571}$ & 0.287 & 0.008 & & 2.131 & 0.943 & 0.340 & 0.433 & 1.551 \\
\hline $1989 / 1990\left(\times 10^{3}\right)$ & 0.050 & 1.247 & 0.260 & 0.238 & $\underline{0.382}$ & 0.112 & & 0.377 & 0.557 & 0.444 & 0.221 & -0.203 \\
\hline $1990 / 1991\left(\times 10^{3}\right)$ & 0.100 & 0.353 & 1.254 & 0.630 & 0.427 & $\underline{0.274}$ & 0.047 & 1.103 & 0.431 & 0.740 & 0.163 & 0.523 \\
\hline $1991 / 1992\left(\times 10^{3}\right)$ & 0.133 & 0.375 & 0.543 & 1.360 & 0.462 & 0.162 & $\underline{0.016}$ & 1.679 & 0.411 & 1.436 & 0.243 & 1.099 \\
\hline $1994 / 1995\left(\times 10^{3}\right)$ & & 0.093 & 0.280 & 0.601 & 0.194 & 0.108 & 0.005 & 1.817 & 0.803 & 1.488 & 0.419 & 1.237 \\
\hline $1997 / 1998\left(\times 10^{3}\right)$ & & 0.150 & 0.433 & 0.146 & 0.114 & 0.017 & 0.006 & 1.433 & 0.287 & 1.053 & 0.146 & 0.853 \\
\hline $1999 / 2000\left(\times 10^{3}\right)$ & & $\underline{0.085}$ & 0.164 & 0.095 & 0.104 & 0.033 & 0.010 & 1.152 & 0.005 & 0.658 & 0.162 & 0.572 \\
\hline $2001 / 2002\left(\times 10^{3}\right)$ & 0.33 & 2.060 & 4.687 & 3.826 & 0.276 & 0.136 & 0.008 & 1.752 & 0.684 & 1.601 & 0.275 & 1.172 \\
\hline $2002 / 2003\left(\times 10^{3}\right)$ & 0.19 & 2.676 & 3.337 & 2.289 & 0.859 & 0.191 & 0.096 & 1.093 & 0.269 & 0.957 & 0.117 & 0.513 \\
\hline $2003 / 2004\left(\times 10^{3}\right)$ & 0.024 & 0.704 & 0.831 & 0.288 & 1.125 & 0.115 & 0.024 & 1.920 & 0.238 & 0.800 & 0.380 & 1.340 \\
\hline $2004 / 2005\left(\times 10^{3}\right)$ & & 62.987 & 15.000 & 11.823 & 3.156 & $\underline{0.434}$ & 0.143 & 1.547 & 0.285 & 1.211 & 0.126 & 0.967 \\
\hline $2005 / 2006\left(\times 10^{3}\right)$ & 0.042 & 1.775 & 3.600 & 3.163 & 1.014 & 0.268 & $\underline{0.115}$ & 1.086 & 0.159 & 0.935 & 0.132 & 0.506 \\
\hline $1975-1984\left(\times 10^{6}\right)$ & 0.001 & 0.043 & 0.149 & 0.022 & 0.117 & 0.007 & 0.065 & 0.292 & 1.641 & 0.281 & 0.489 & 0.288 \\
\hline$\underline{1985-1992}\left(\times 10^{3}\right)$ & $\underline{0.135}$ & $\underline{22.593}$ & $\underline{12.952}$ & $\underline{0.571}$ & $\underline{0.382}$ & $\underline{0.274}$ & $\underline{0.016}$ & $\underline{1.584}$ & $\underline{0.817}$ & $\underline{1.359}$ & $\underline{0.200}$ & $\underline{1.004}$ \\
\hline$\underline{1999-2006}\left(\times 10^{3}\right)$ & $\underline{0.024}$ & $\underline{0.085}$ & $\underline{4.687}$ & $\underline{2.289}$ & $\underline{1.125}$ & $\underline{0.434}$ & $\underline{0.115}$ & $\underline{1.138}$ & $\underline{0.121}$ & $\underline{0.907}$ & $\underline{0.084}$ & $\underline{0.558}$ \\
\hline $1975-1992\left(\times 10^{6}\right)$ & 0.061 & 0.188 & 0.409 & 1.119 & 0.860 & 0.215 & 0.028 & 1.708 & 0.212 & 1.242 & 0.319 & 1.128 \\
\hline $1994-2006\left(\times 10^{3}\right)$ & 0.721 & 20.766 & 30.590 & 22.487 & 13.416 & 2.951 & 0.660 & 1.506 & 0.005 & 0.970 & 0.192 & 0.926 \\
\hline $1975-2006\left(\times 10^{6}\right)$ & 0.503 & 3.442 & 5.990 & 10.131 & 7.412 & 1.800 & 0.262 & 1.672 & 0.167 & 1.238 & 0.293 & 1.092 \\
\hline
\end{tabular}



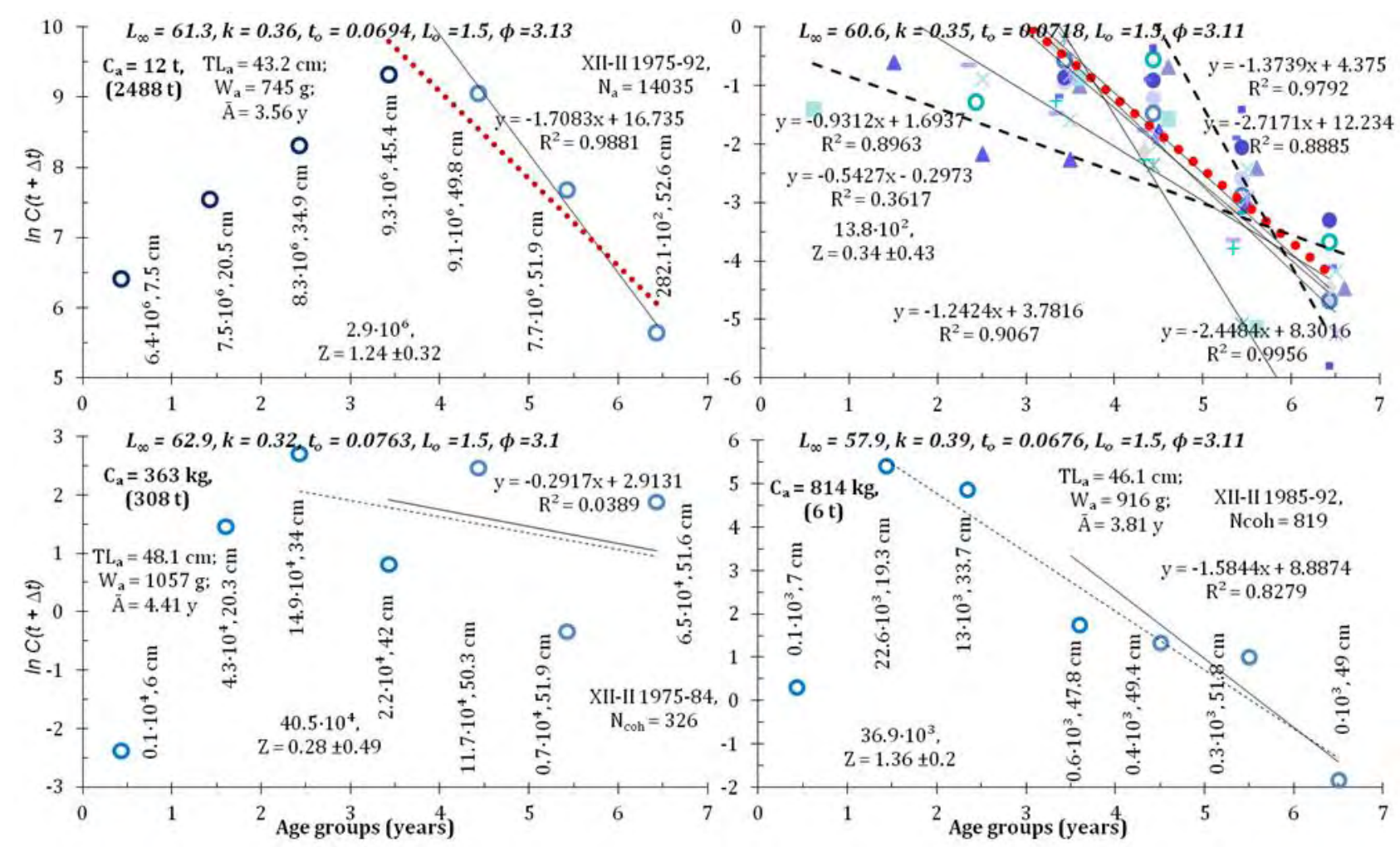

$L_{\infty}=57.9, k=0.39, t_{o}=0.0676, L_{o}=1.5, \phi=3.11$
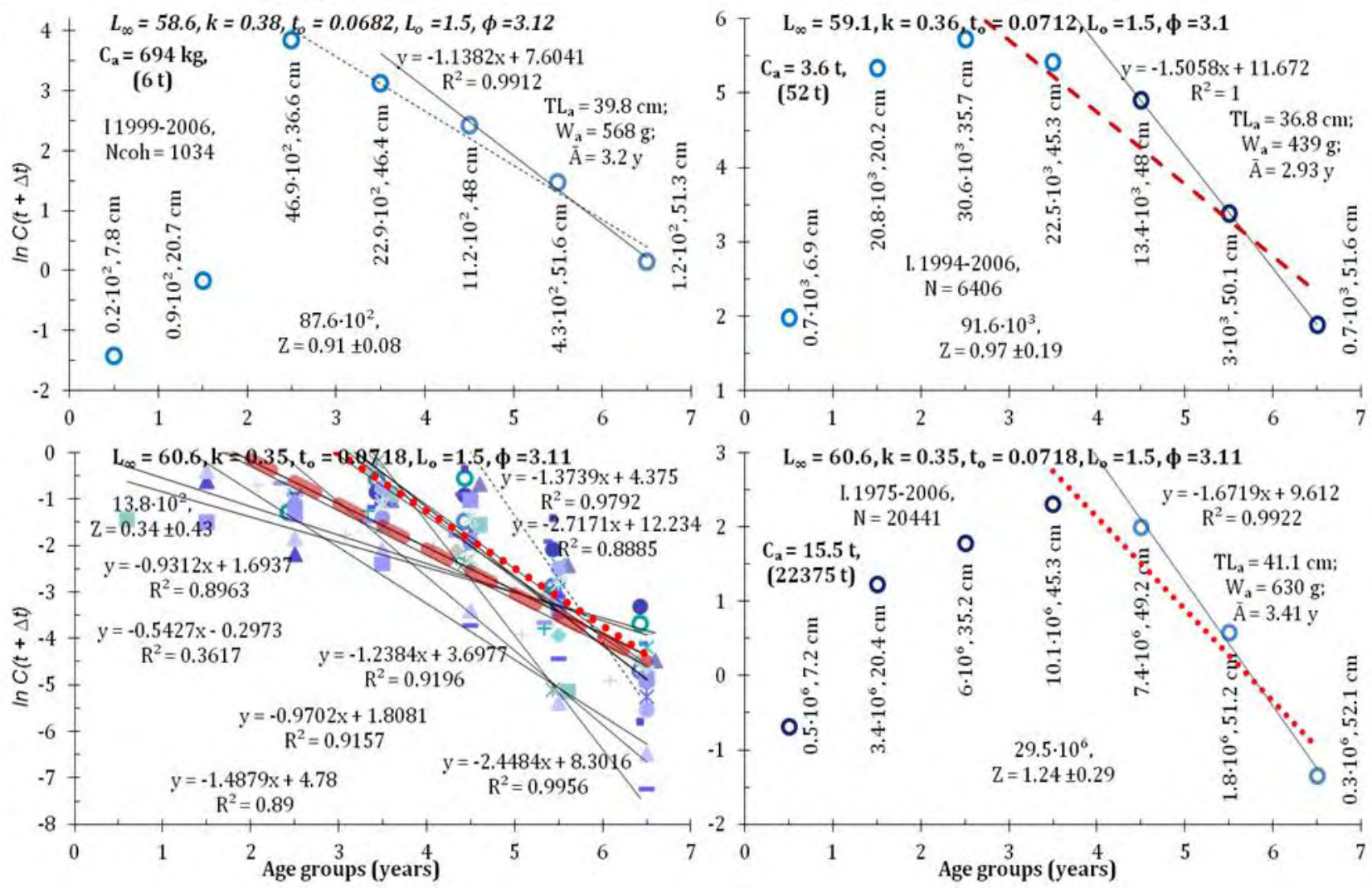

Fig. 35 Average total mortality during large catches in 1975-1992 is $Z=1.24$, it oscilate around average from 2.7 when only large fish were cought to $\mathbf{0 . 5 4}$, even $\mathbf{0 . 3 4}$, in the years when smaller and younger fish fully enter to fishery, because of lack of larger one, in the cohort 1975-1984, 6 age group was large fished, but in cohort 1985-1992 and 1999-2006, all young fish from 1-4 age groups were large fished as $Z$ line include them, in the last period, $Z$ oscilate around new average 0.97 per year. 


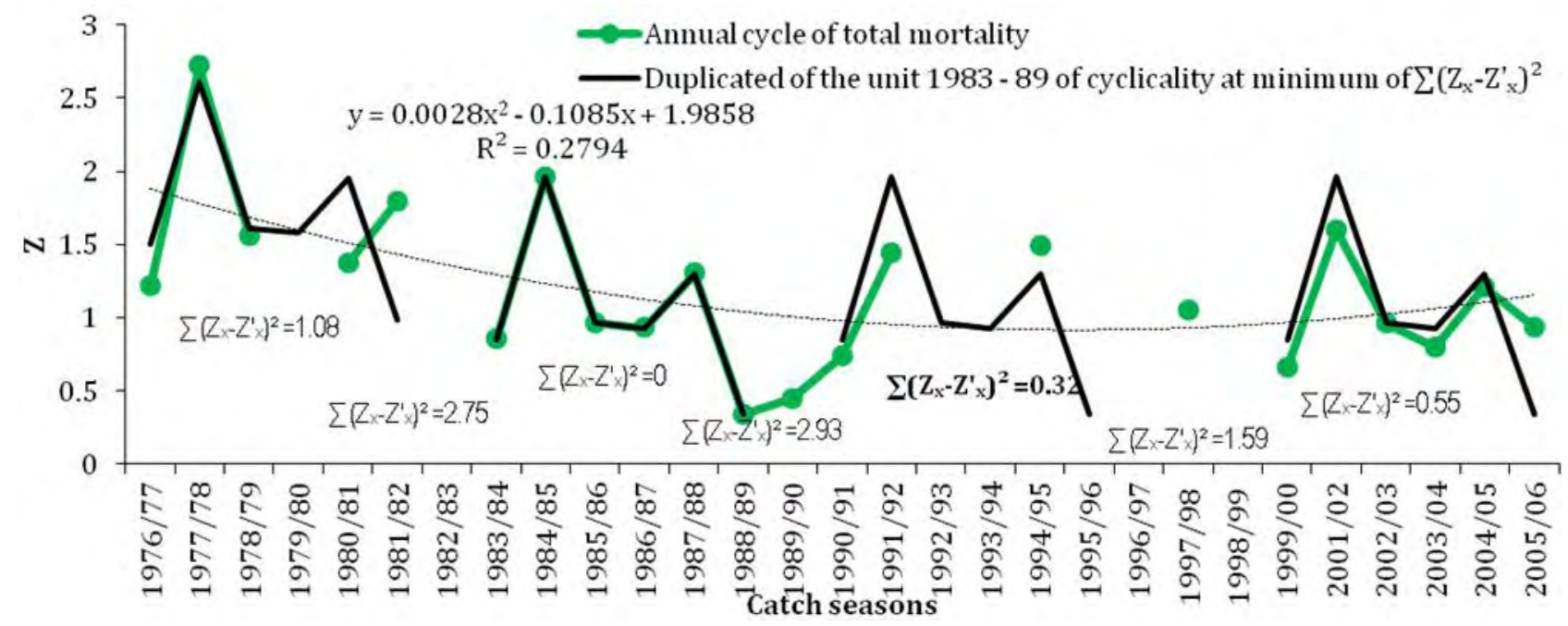

Fig. 36 Total mortality from period 1983-1989 have replicates with minimum of squared differences show in catch history.

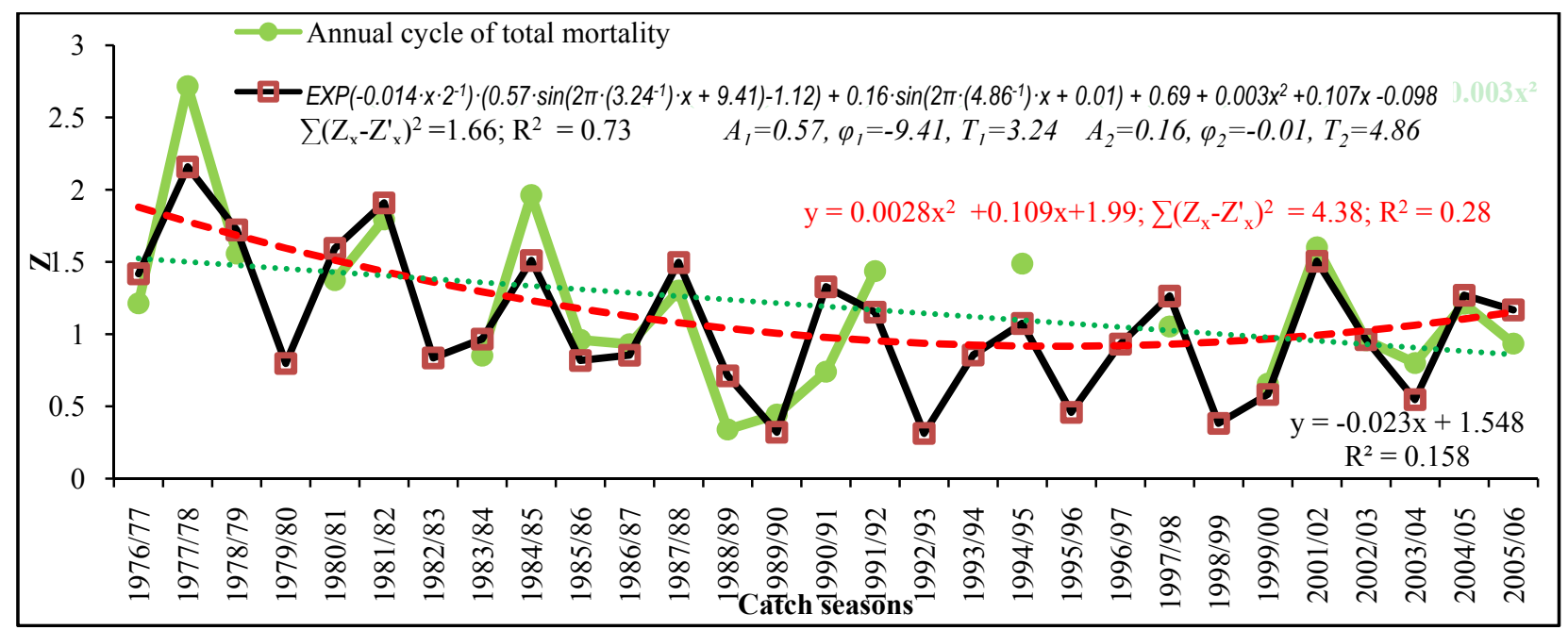

Fig. 37 Oscyllation total mortality of Pseudochaenichthys georgianus around average 1.5 with amplitude 0.6 and 0.16 , and with 8 years cycle.

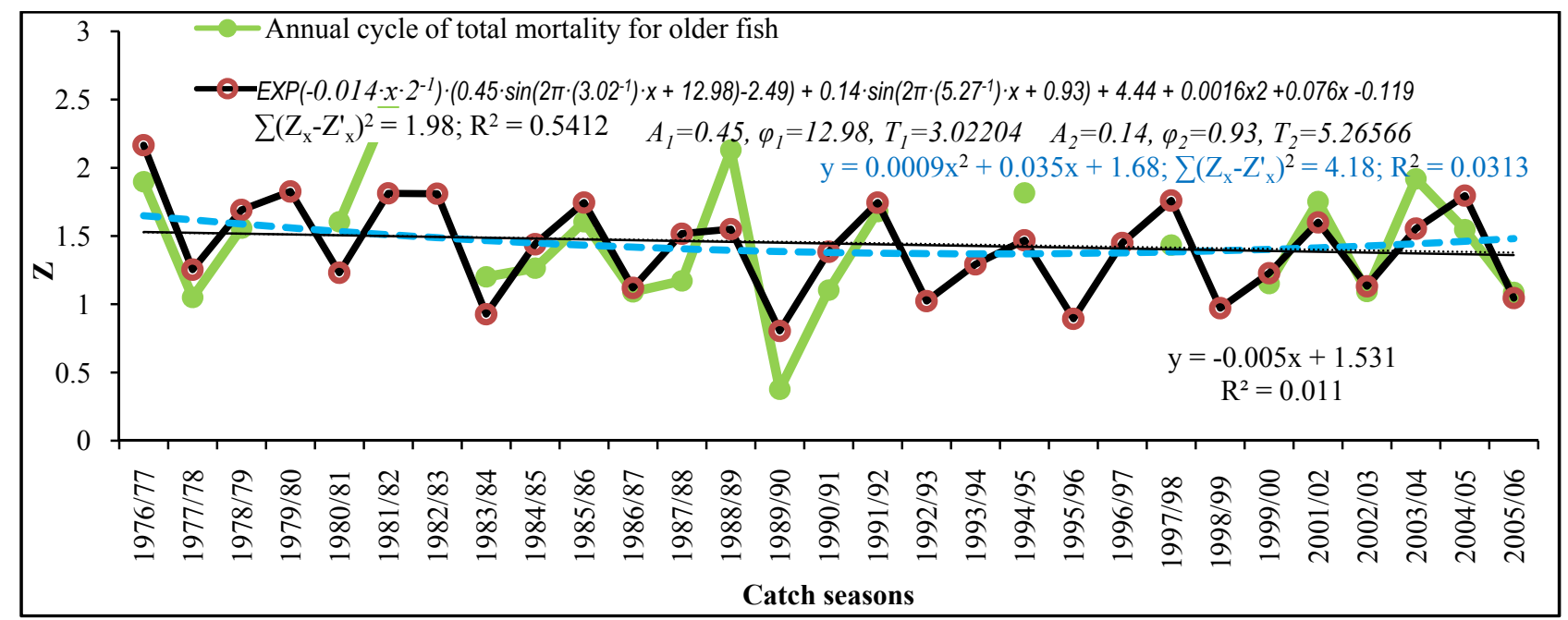

Fig. 38 Oscyllation total mortality of older Pseudochaenichthys georgianus around average 1.5 with amplitude 0.5 and 0.1 and with 8 years cycle. 


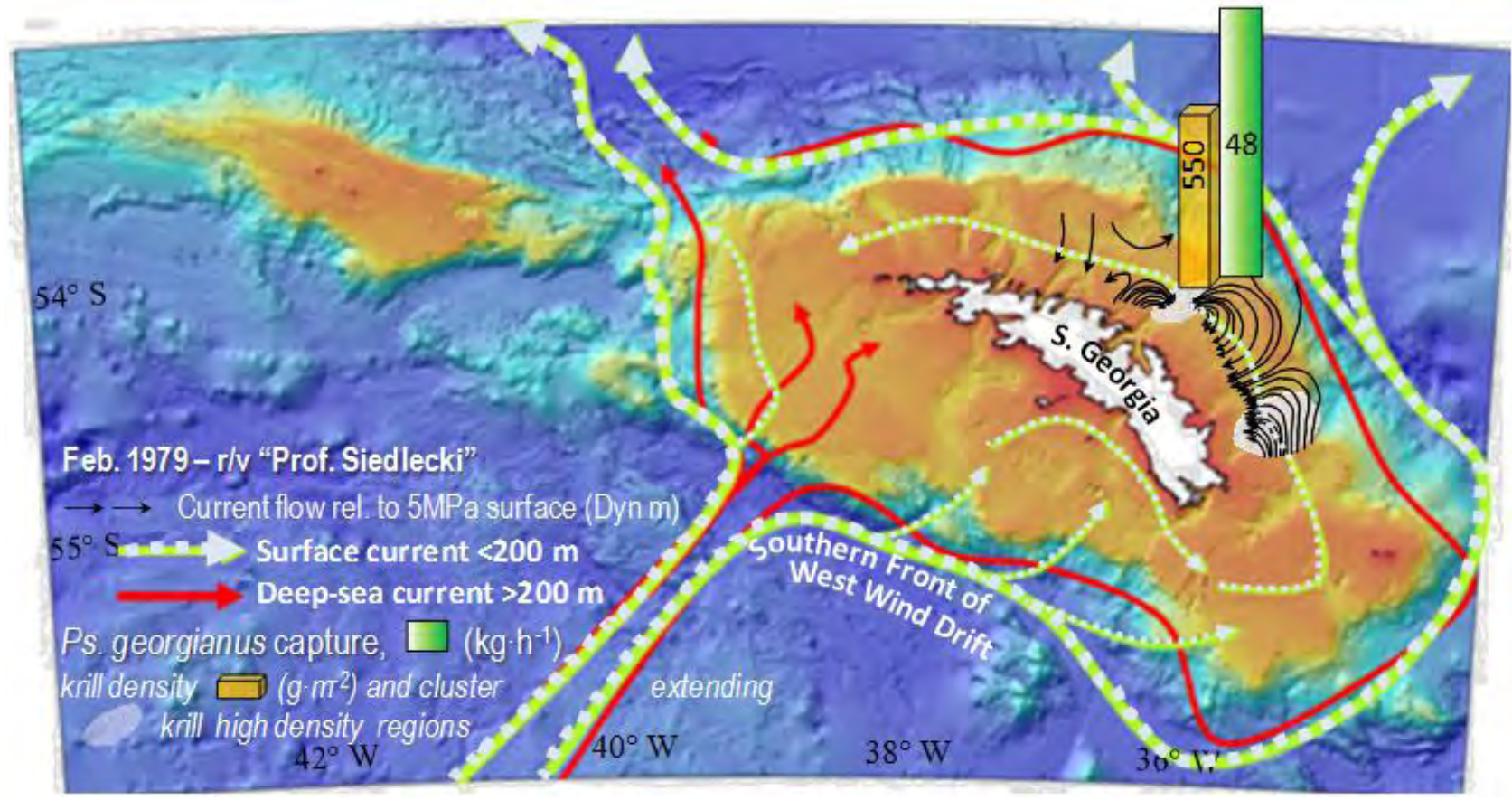

Fig. 39 Main fishing area of fish and krill.

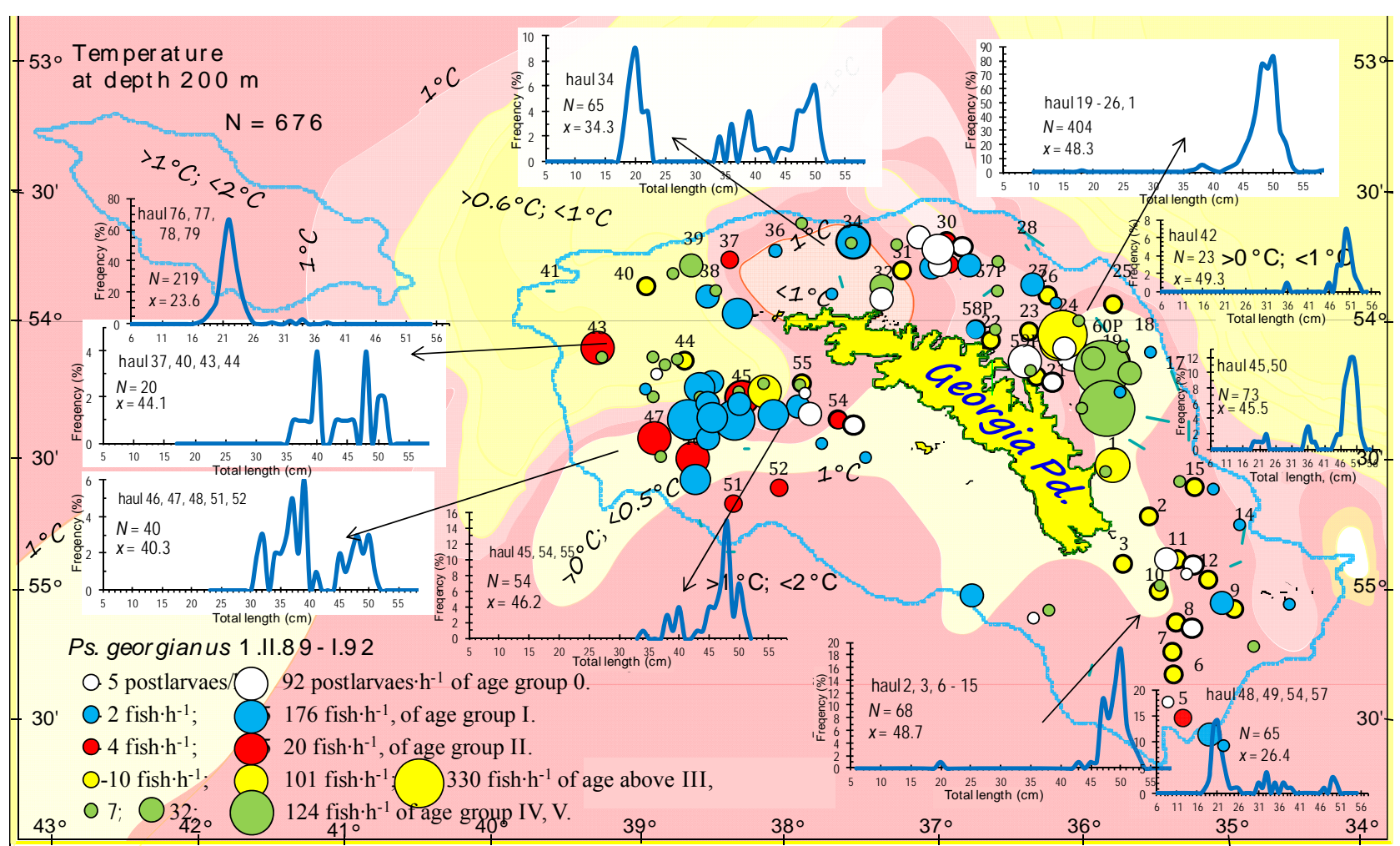

Fig. 40 Distribution of age group of fish on the shelf of South Georgia Island $\left(\times \mathrm{h}^{-1}\right.$ or $\left.\times 8.82 \mathrm{~km}^{-2}\right)$. 


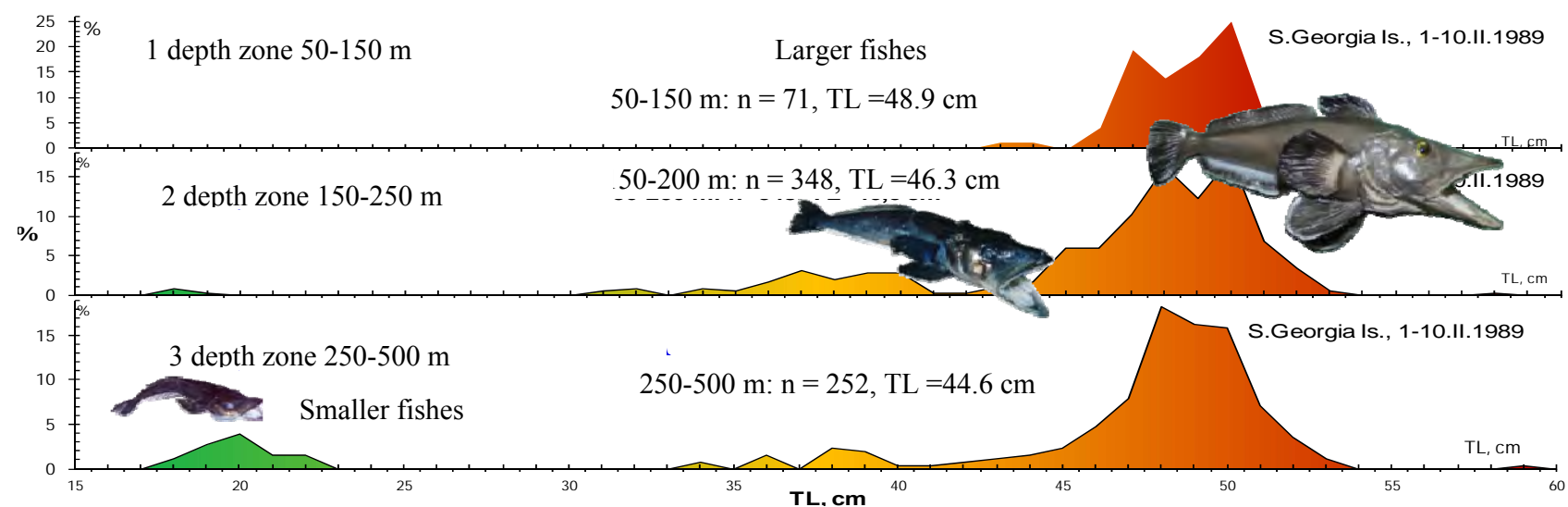

Fig. 41 The vertical distribution of the young age groups and the older (their separations).

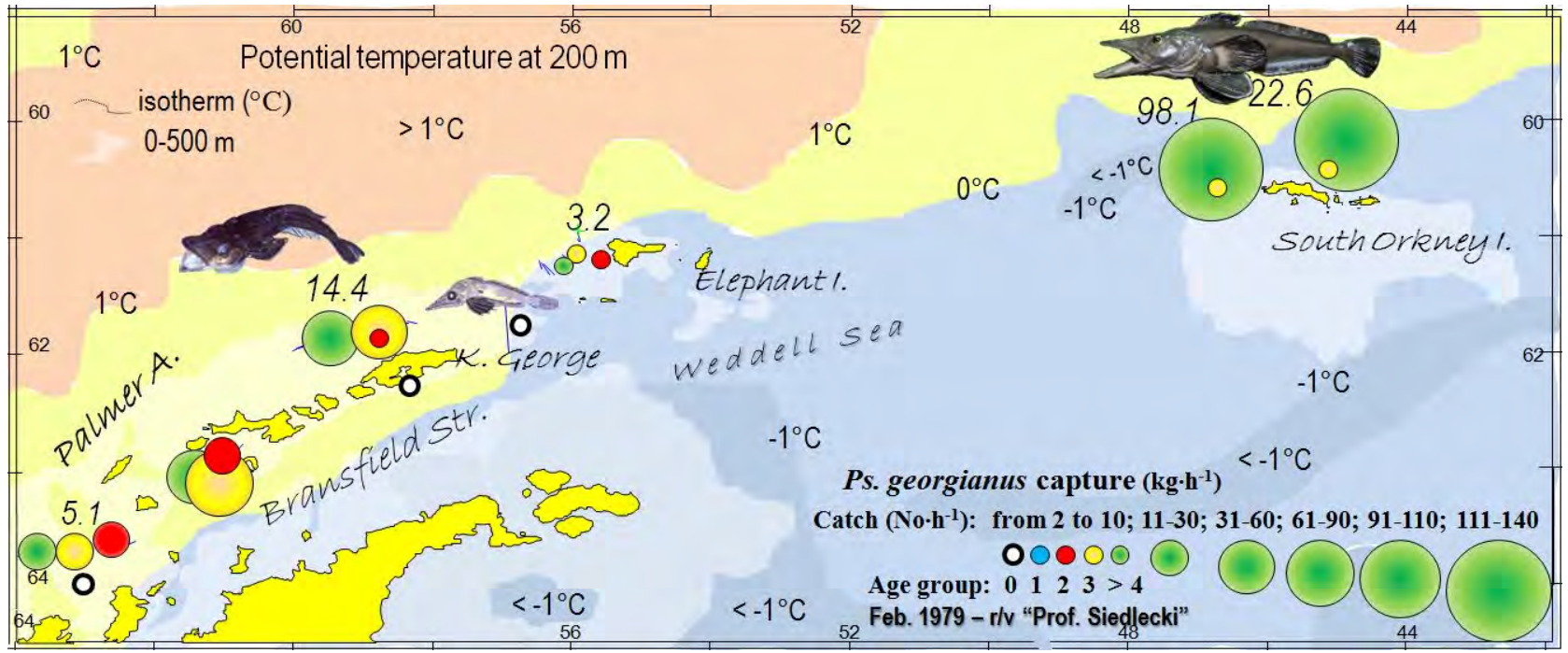

Fig. 42 Catches of Pseudochaenichthys georgianus in Antarctic zone, $\left(\times \mathrm{h}^{-1}\right.$ or $\left.\times 8.82 \mathrm{~km}^{-2}\right)$.

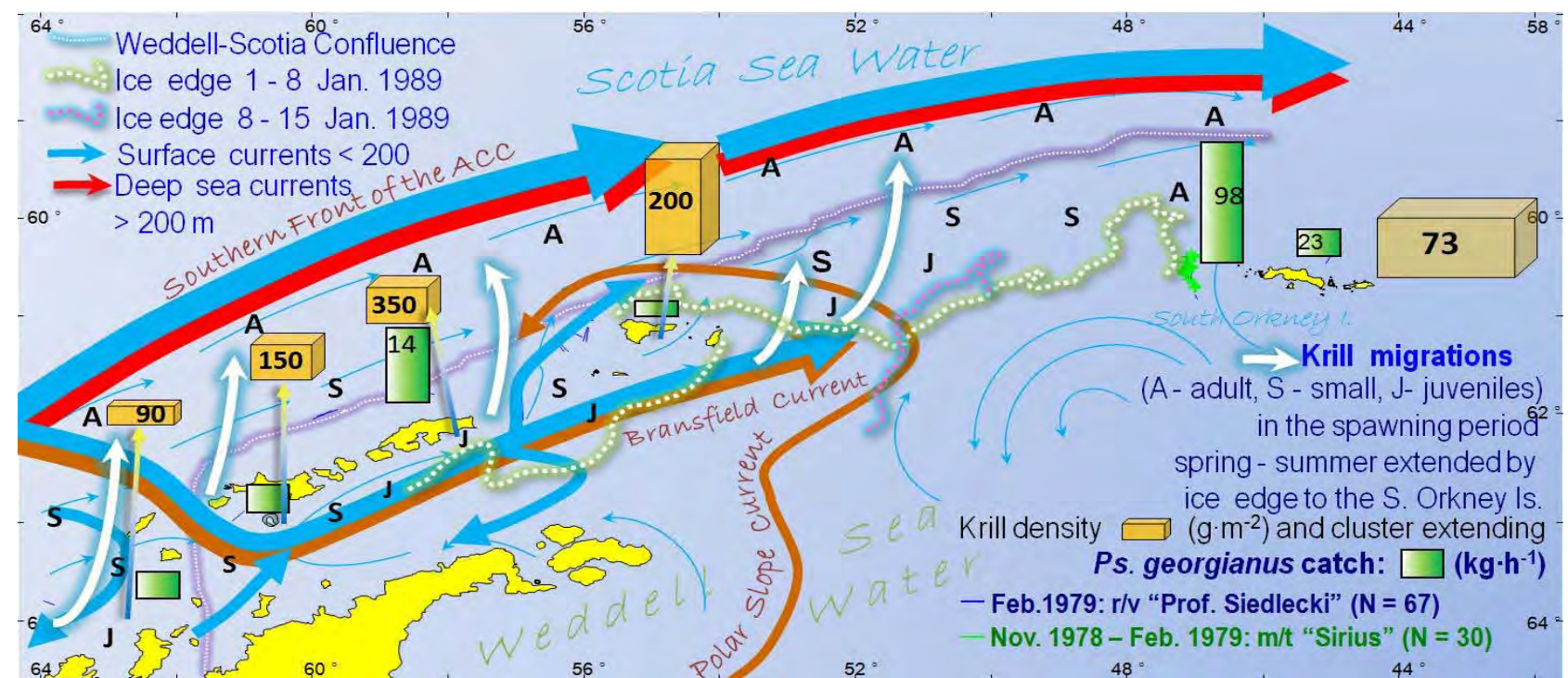

Fig. 43 Adult Pseudochaenichthys georgianus were catched along the continental slope were adult krill migrate for spawning, the southern front of the Antarctic Circumpolar current may lead them to the north-east at South Orkney shelves, on the southern shores of South Shetland, there were small and juvenes both krill and Pseudochaenichthys georgianus, that live deeper, in that places Bransfield current, deep branch of the SF ACC may carries them to south side of South Orkney. 


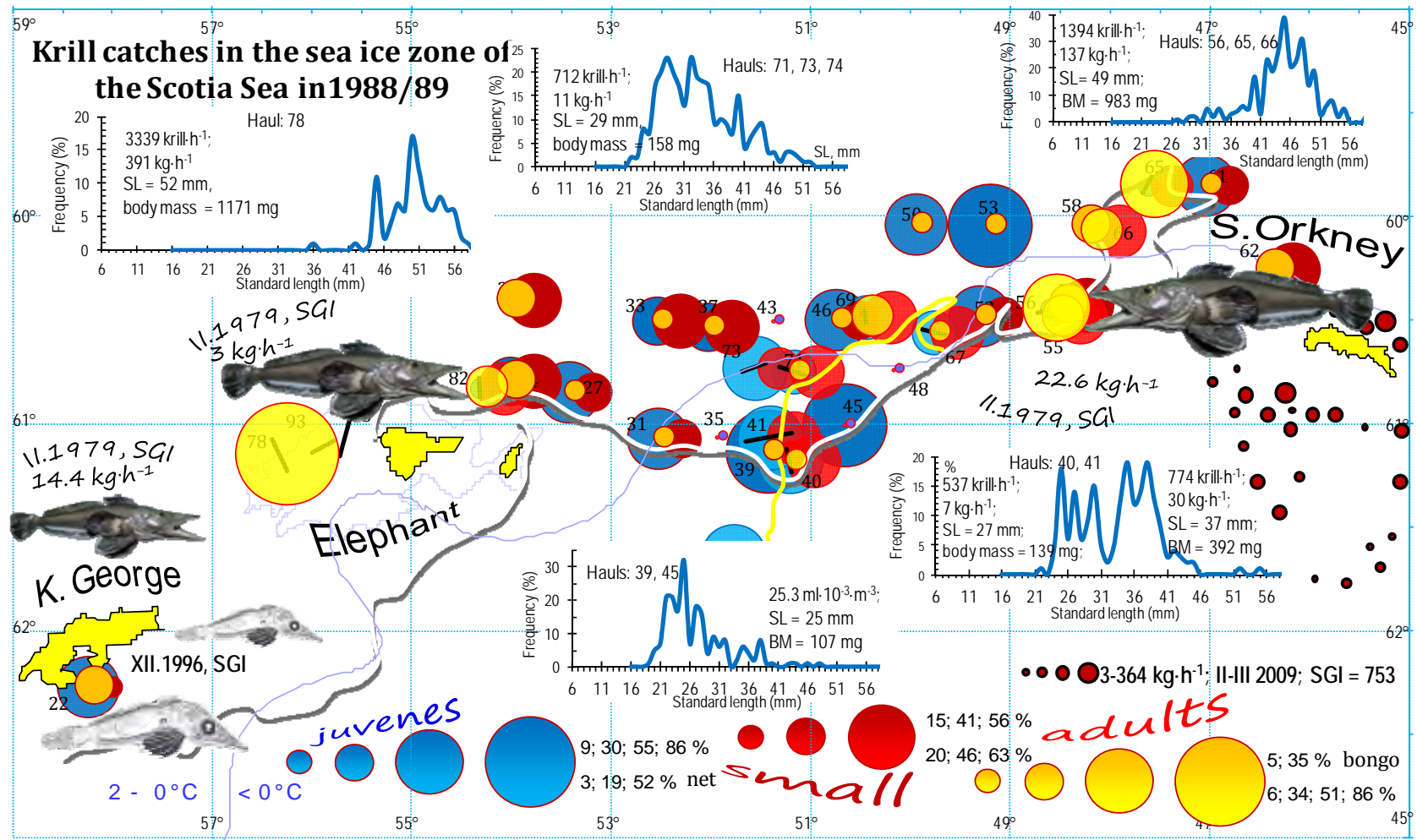

Fig. 44 The same was in ecological research in north-eastern shores islands with strong current and larger adult krill have older and larger of Pseudochaenichthys georgianus, on west and southern shores of the King George Island, there were small juvenes krill and larvae of Pseudochaenichthys georgianus that can be dispersed from west with Bransfield current.

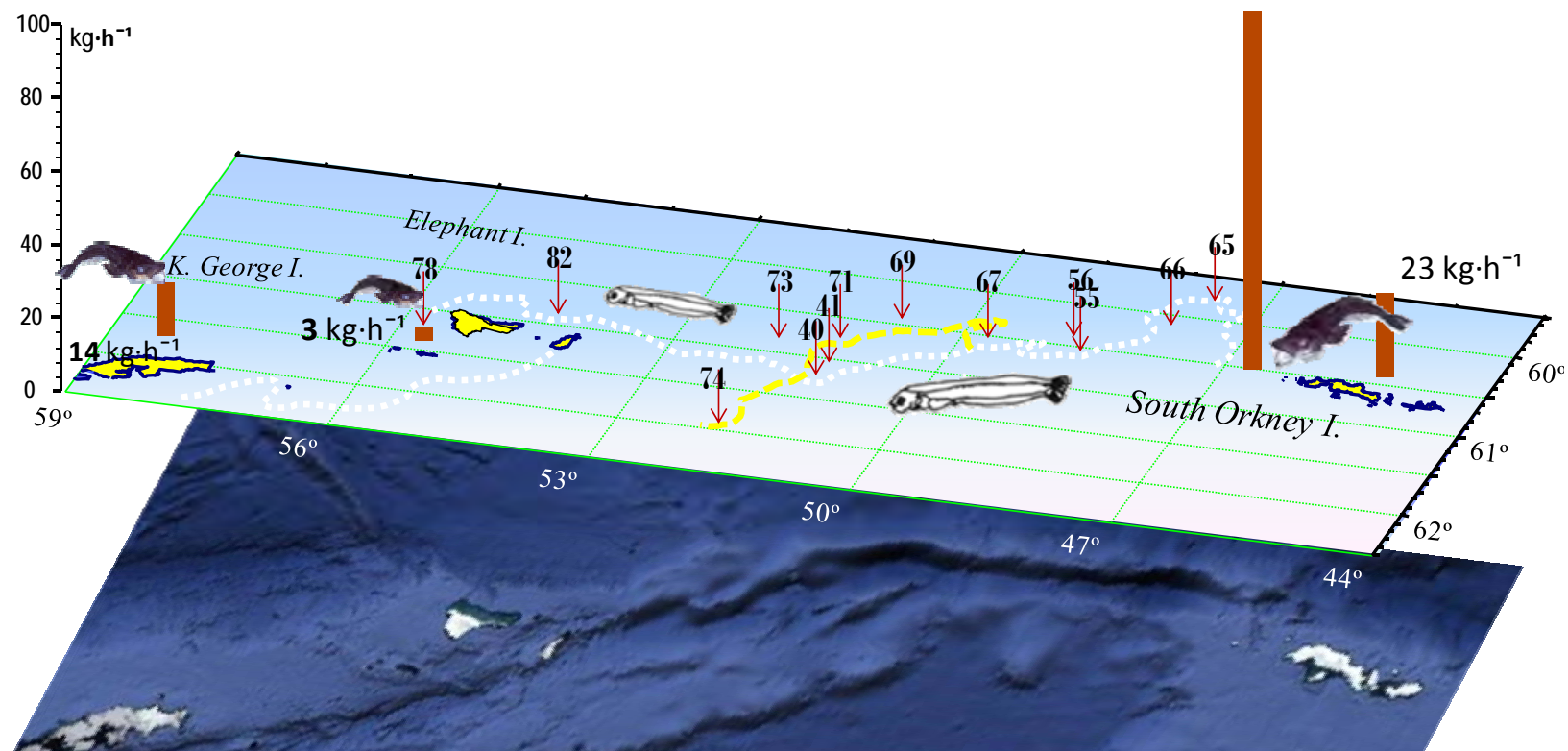

Fig. 45 Larvae of fish in the krill catches (marked by arrows) on r.v. "Professor Siedlecki" in season 1988/1989, fish larvae (station no.): Chaenocephalus aceratus (40, 66), Champsocephalus gunnarii (41), Chionodraco rastrospinosus (41, 66 and 78$)$ Chaenodraco wilsoni (69, 73 and 74), Dissostichus eleginoides (73), Pleurogramma antarcticum (40 and 74), Cryodraco antarcticus (40, 73, 74 and 82), Neopagetopsis species (55), Neopagetopsis ionach (56, 71 and 73), Trematomus eulepidotus (65), Notolepis coatsi (67 and 71), Pagetopsis species (69, 78 and 82), Notothenia species (69), Lepidonotothen larseni (73 and 74$)$, Pagetopsis macropterus (73) and Electrona carlsbergi (78) [29]. 
Where caught of this species were large $\left(48 \mathrm{~kg} \cdot \mathrm{h}^{-1}\right)$, krill density was high $\left(550 \mathrm{~g} \cdot \mathrm{m}^{-3}\right)$. Where fish caught were less $\left(5 \mathrm{~kg} \cdot \mathrm{h}^{-1}\right)$, krill was only $90 \mathrm{~g} \cdot \mathrm{m}^{-3}$ (Fig. 2) [47].

The overall results of fishery of Pseudochaenichthys georgianus also illustrate the strong it dependence from krill densities. During the period 2002-2011 at low krill fishery of about 100,000 $\mathrm{t} \cdot \mathrm{y}^{-1}$, there were $24,000 \mathrm{t} \cdot \mathrm{y}^{-1}$ of icefishes. When krill fishery was doubled to about $200,000 \mathrm{t} \cdot \mathrm{y}^{-1}$, the accompanying decrease of fish biomass has enabled to catch of them two times less, only 12,000 t per year (Fig. 8). So, as catch of krill is maintain at high level, catches of Pseudochaenichthys georgianus is dropped to $1 \mathrm{t}$ and below, near $0 \mathrm{t}$ (Figs. 8 and 13).

Krill determine directly adaptation of the icefish geographical and vertical distribution, as food for juvenile and adults at large depth, they migrate after krill (Figs. 40-43) [10]. It appears that clusters of krill also serve as shelters and an environment for the development of larvae of many fish species (Fig. 45). It is know that clasters, schools are defensive strategy that provides individuals greater security and therefore increase the chance of survival. Krill in large densities modifies the raw physical-chemical properties of Antarctic waters to favorable for their development and also for larvae. Densely aggregations of krill form a "moving, living ocean" which causes bio-turbulence of water in the size of the effects comparable to mixing of water during the tide or wind [48]. The movements of water arising in the movements of billions legs of krill during their vertical and geographical migrations, carry them with the water and cause mixing of minerals, nutrients and gases [49]. Thanks to this, they oxygenate the water, activate the suspended and dissolved compounds. Also krill metabolism multiplied billions of times modifies water in its clusters (raising their temperatures). In them for these reasons, fish larvae are going to live and get a shelter. By catch of fish larvae and juvenile in krill fishery mostly consist icefish species in significant numbers (Fig. 45) [50].

The high density of krill feeding on huge biomass of phytoplankton and ice algae ensue the main food for fish (15 million ton per year), squid (65 mln), seals (96 mln), whales (137 $\mathrm{mln}$ ), penguins and other Antarctic bird (18 mln). Reducing that density cause increase of food competition between fish, seals, whales, penguins and bird in which icefish as we see is not a winner. A part of high predatory pressure from fur seals (from 5 million at South Georgia Island), albatrosses, penguins in recent time of poor krill availability conditions of icefish are worst and larger quantities are became consumed by predators normally krill depended [10, 20]. Krill showed a significant decrease across the whole SW Atlantic sector during the period 1976-2003 [18].

Icefish larvae deprived of krill environment simply could not survive. In the absence of sufficient krill (energy), the Antarctic fish may experience inhibiting the development of eggs and in consequence withholding spawning and lack of recruitment [51]. Krill also ensue transport of $\mathrm{CO}_{2}$ from biosphere that stay in biological cycle for 1,000 years in ocean. Its excrement reach in organic coal fall to the ocean bottom.

\subsection{Causes of Decline in Krill Density}

The decrease in the amount of krill is from four joined causes:

(1) The increased temperature from global warming inhibit growth of krill. As species inhabiting the seasonal sea-ice zone krill growth fastest at about $0.5^{\circ} \mathrm{C}$, and in warmer temperatures at South Georgia Island, its growth is slow. There are declining habitat suitability for Euphausia superba [21]. Krill density decrease with increasing temperature with equation: $y$ $=-0.25 \cdot x+2.24[21]$;

(2) The global warming reduced the ice cover. Nowadays ice cover has very small range (Fig. 46), while in the 1980s in winter, it can reach South Georgia Island, in summer, it can reach South Orkney. 
Ice algae colonise snow and ice column on depth are appropriate to its photosynthesise light. Their colour pigments (red, orange lipids or yellow green) care them before light and UV. Some species live under the ice. In the summer, their bloom reach $10^{5}-10^{6}$ cells per cubic meter. In the ice edge zone, the base of food ladder are rather ice algae than pelagic phytoplankton. Many species of Calanus and Oithona feeding on ice algae, before phytoplankton bloom reproduce under the ice and became large food source for fish, larger one for adults, smaller species with larval stages for fish larvae. In the ice-edge zone, there are large accumulate phytoplankton and zooplankton, birth and sea mammals, what create high biological activity. In summer, melting ice in ice edge zone generate high stability (with lesser salinity) surface water having optimum conditions for growth of phytoplankton and for young stages of krill and fish larvae that can hide in ice crevices before predators. As ice cover generates high biomass of ice algae, krill feeds on it under the ice up to $13 \mathrm{~km}$ to south. There are high densities about 30,000 individuals per $\mathrm{m}^{3}$, together with Calanus sp., and Oithona sp. [52]. They became their eggs and naupli, a base food for fish and their larvae. Additionally, in summer, a great amount of phytoplankton from melting ice initiate their flourish producing large biomass equals to half of all production of southern Ocean. In summer, when flourish of ice alge is equal to $10^{6}$ cells per cubic meter, krill development (feeds on it) reach up to 13 million to some billions tons a year [52]. Lack and disharmony in cover of ice sea cause disappear half food source for krill and then decline of krill density. In recent years, the biomass of algae is increasing, that indicate small prey of krill on algae because of krill decrease from different reason than lack of food [53];

(3) Next cause partially became previous. Lack of ice cover allows the extreme southern winds to move ACC current with krill to the south that deprives shelves habitat of South Georgia Island from the basic foot (Fig. 47). Typically, krill is carried from South Shetland Island, and from the Weddell sea through Bransfield Strait into the Antarctic Circumpolar current up to outside of South Georgia Island. That krill migration with the ice cover was not only save from wind, but was greatly larger than on open sea since thousand kilometres under ice was natural food factory saving great density of krill;

(4) Fourth cause for decrease of krill density also become from smaller ice covering. Smaller surface of ice cover allow fishery to catch krill every day every year from larger area of sea free from ice cover than from currently smaller resources in 1970 (Fig. 46). Krill showed a significant decrease across the whole SW Atlantic sector during the period 1976-2003 [21]. Previously, larger krill resources were under 2 time larger ice cover and because of that, they were untouched by caching. No one ship catch near ice, except research (Fig. 48). There are catch data only from north of South Orkney Island, the only area that were free from ice cover in 1970's (Fig. 45). Later in 1999 and 2009 when ice cover decrease and disappear from southern shelves, there appear catches from the southern shelves (Figs. 3 and 44).

\subsection{The High Contamination of Fish in Countries with the Largest Supply of Antarctic Fish}

Exploitation of living Antarctic stocks is close related with Atlantic and Pacific fish contamination. Norway, Japan, Korea and France have the largest participation in the Antarctic fishing (Fig. 49). These countries have a high consumption of fish and very high demand, that drive their fishery on Antarctic for large fish. The closer Atlantic and Pacific stocks and their seas, lakes and rivers are overfished and polluted by toxins [54]. Mercury content (as well as PCBs) in fish in some places on level more than $0.3 \mathrm{ppm}$ excludes from human consumption, including tunas, walleyes, mackerels, marlins, eels, bluefishes, croakers, sharks, swordfishes and flounders [55-58]. These fish and others in other locations contain less mercury, 


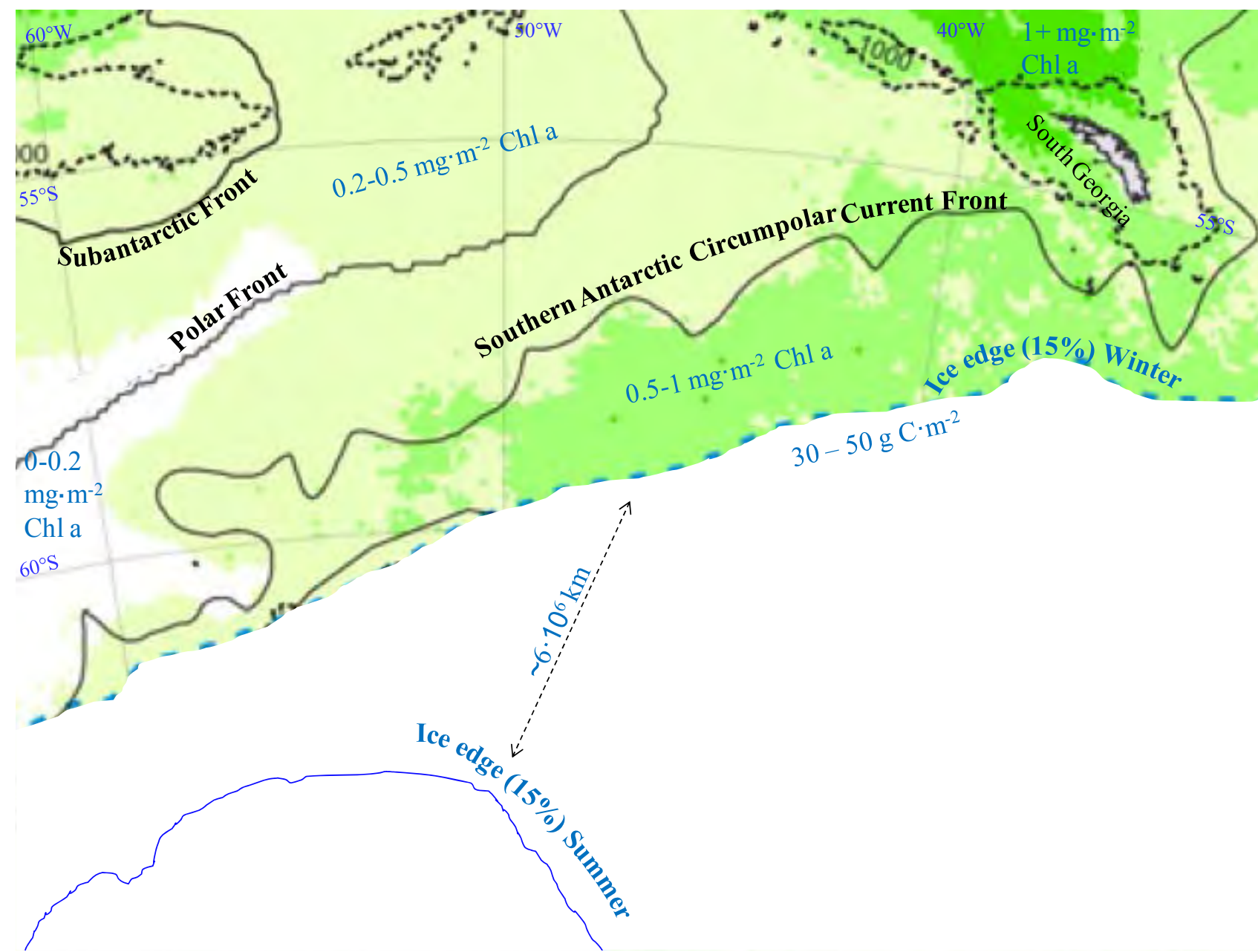

Fig. 46 Recent position of northern ice edge, in 1970's in Summer ice edge reach up to South Orkney and cover southern part of shelf (Fig. 45), in winter of 1970's, ice edge could reach South Georgia Island, under ice, juvenile krill preying in an inverted position, harvest algae sediment from the bottom of the ice as a lawn mower (by approximate 6 years, until the adult form), layer of algae deposited on the bottom of the ice contain more organic carbon than the entire water column under the ice, during the spring bloom of ice algae underside of the ice is a major source of energy [52].

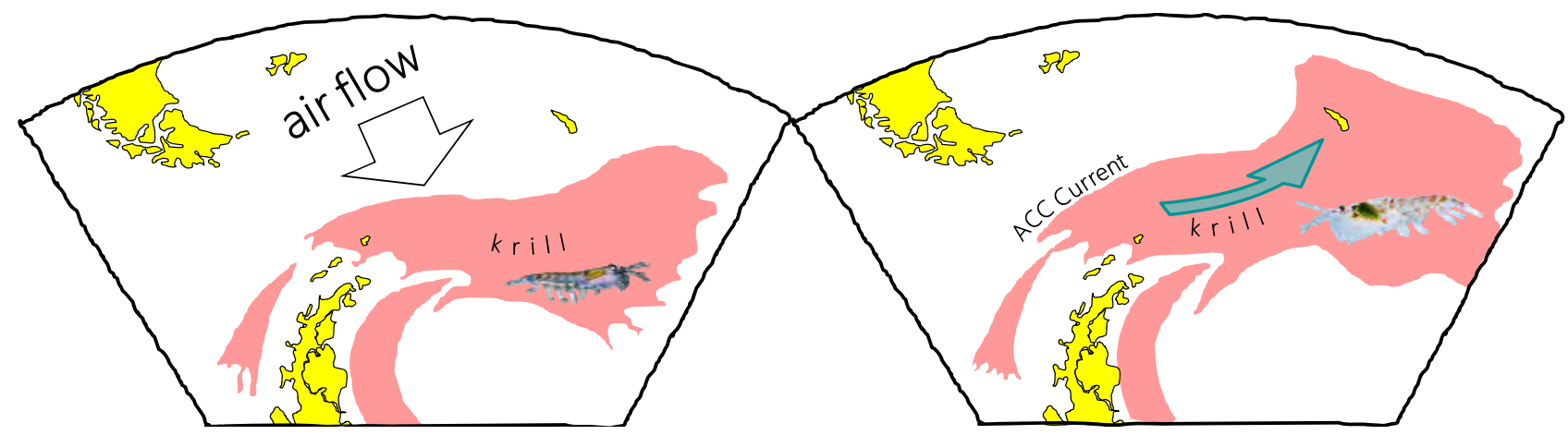

Fig. 47 Move of ACC by wind [52]. 


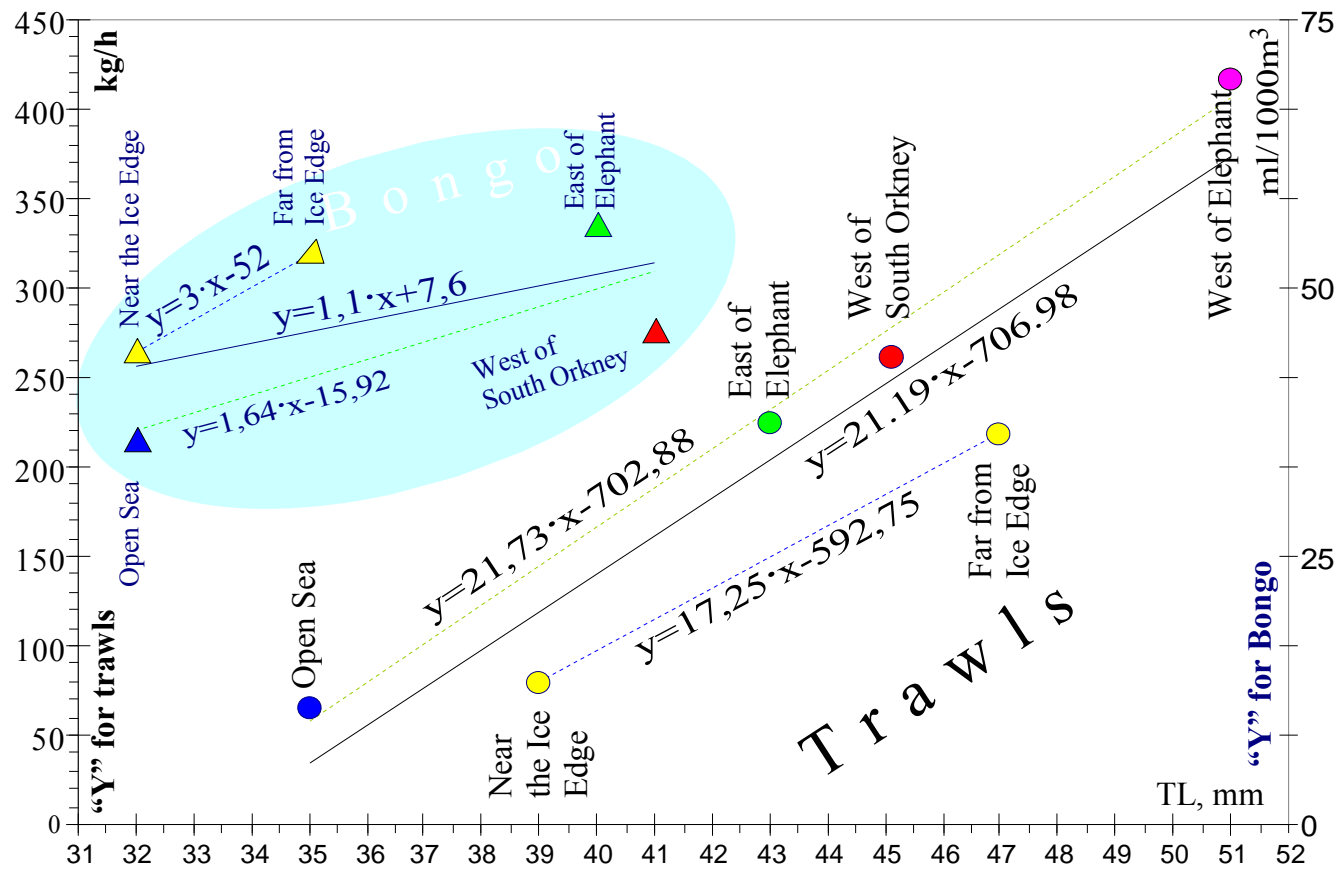

Fig. 48 Plot of total length versus krill abundance in subareas and in the ice edge zone between Elephant Island and South Orkney Island (December 1988-January 1989).

0.09-0.29 ppm can be consumed, but in very small amounts, for example, by children, not more than successively $4.3 \mathrm{dg}, 8.5 \mathrm{dg}$ and $15 \mathrm{dg}$ per month depending on the concentration of toxins. Because the nervous system of children is still in a period of strong development, here they are also more at risk for damage to the nervous system. It is worth emphasizing, that fetuses accumulate the mercury in the blood to a concentration of 1.5 higher than in the maternal blood [59]. Mercury also as toxin, chemically modify the DNA, the symptoms of poisoning are also present in the progeny, it has been detected in the third generation $[60,61]$.

Sometimes, source of mercury is natural: cinnabar (mercury sulfide) ore deposits along the bottom of the Mediterranean sea, create very high levels of mercury in Mediterranean's tuna. Although there are 28 species contaminated by mercury less than $0.09 \mathrm{ppm}$, some of them farmed (such as salmon) may contain PCB's, chemicals with serious long-term health effects, dioxins and pesticides. Additionally, 19 species are low in numbers or falling to destruct [62]. In spide of mercury threat, there are leaked radiations from nuclear power plants. From the Fukushima Daiichi plant after earthquakes and tsunami in 2011, about 300 tons of contaminated water by cesium and strontium isotopes is pouring into the sea every day [63]. Even that, the Kuroshio current and Kurushio extension are diluting radioactivity, which eddies and giant whirlpools continue on the vast ocean coastal areas, the radiation levels in the sea around plant have been holding steady and demonstrating that radiation leakage is not stop. At least, 42 fish species from that area are not safe, have high levels of cesium-134, (a radioactive isotope that decays rapidly) and strontium-90 (that is absorbed in the bones). That radioactive contamination event is small cell of large chain of more than 2 thousand explosions in the seas performed by several countries since human start nuclear explosion testing in 1945 in Alamo Gordo, USA [64].

Because of these numerous impurities, in above countries, where there is high consumption rate of fish, there is a much higher risk from not only one but from numerous different poisons: mercury compounds, radionuclides, $\mathrm{PCBs}$ and plastics, which accumulate in the fish. Their influences are not deactivate but add one to the other. 
Norway: Farmed salmon from their coast eat wild fish compressed into food pellets, that are soaked with fish oil causing farmed salmon to be much fatter. Many toxins bind to fat, persistent organic pollutants accumulate in farmed salmon fat, transferring to people who eat it and causing negative effects (the problem could be resolved by replacing fish oil from fish food to algae oil) [65]. In addition, Norwegian salmon reared in cages comes from the Barents sea, whose major problem is its radioactive pollution originating from Russian nuclear fleet and the Norwegian processing plant of radioactive waste and at last from landfills dump to the sea since the $1950 \mathrm{~s}$ [66-71].

In fish caught in the Barents sea in the otoliths microstructure, a large changes were frequently found, Fig. 50, which are likely to result from these pollutants [72].

France: like Britain, it has the economic advantage of having a back-fishing in their territory in the CCAMLR convention area, so it has a cheaper cost of fishing in the Antarctic. France has fishing facilities in Kerguelen Islands, Crozet, Adelie land in the Indian sector. The fishing fleet of these territories pay lower taxes and has less stringent regulations. Exploitation of living resources by this fleet gives income of $\$ 18$ million. French cuisine absorbs the catch of any fish, crabs and shellfish. Their coastal waters are seriously polluted.

In the La Hague, reprocessing plant of nuclear fuel in France produces significant contamination of radioactive elements. In ordinary operation of nuclear power plants, replacement of cooling water in the reactor also increases the level of radioactivity in water. Wastes from nuclear power plants have an impact on the marine life on the vast areas: radioactive elements from the processing of the fuel are in the seaweed up on the coast of Greenland and along the coast of Norway.

Britain has a record of air pollution compounds with concentrations above the scale [73]. The Sellafield site in the UK is nuclear fuel reprocessing plant being two of the most significant sources of radioactive elements.

England in the Atlantic sector of Antarctica, at South Georgia Island, has a settlement (a small port), Grytviken and near the CCAMLR convention area on the Falkland Islands, has a fishing base in Port Stanley. So, France has lower costs of transport and labour as well. On the shelf of the South Georgia Island and Kerguelen are caught mostly toothfish. Fishing gave her \$6 million profit.

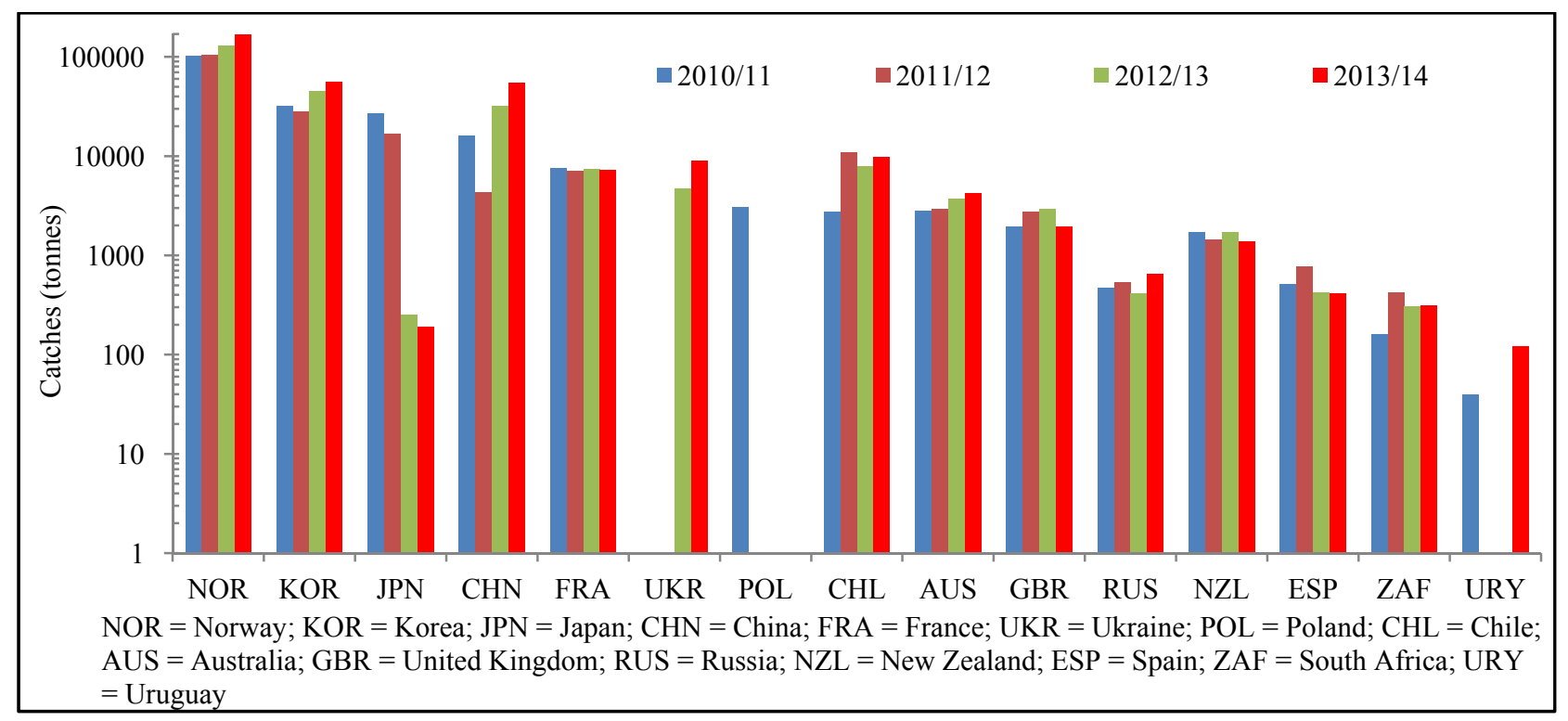

Fig. 49 Countries involved in exploatation of Antarctic living resources. 


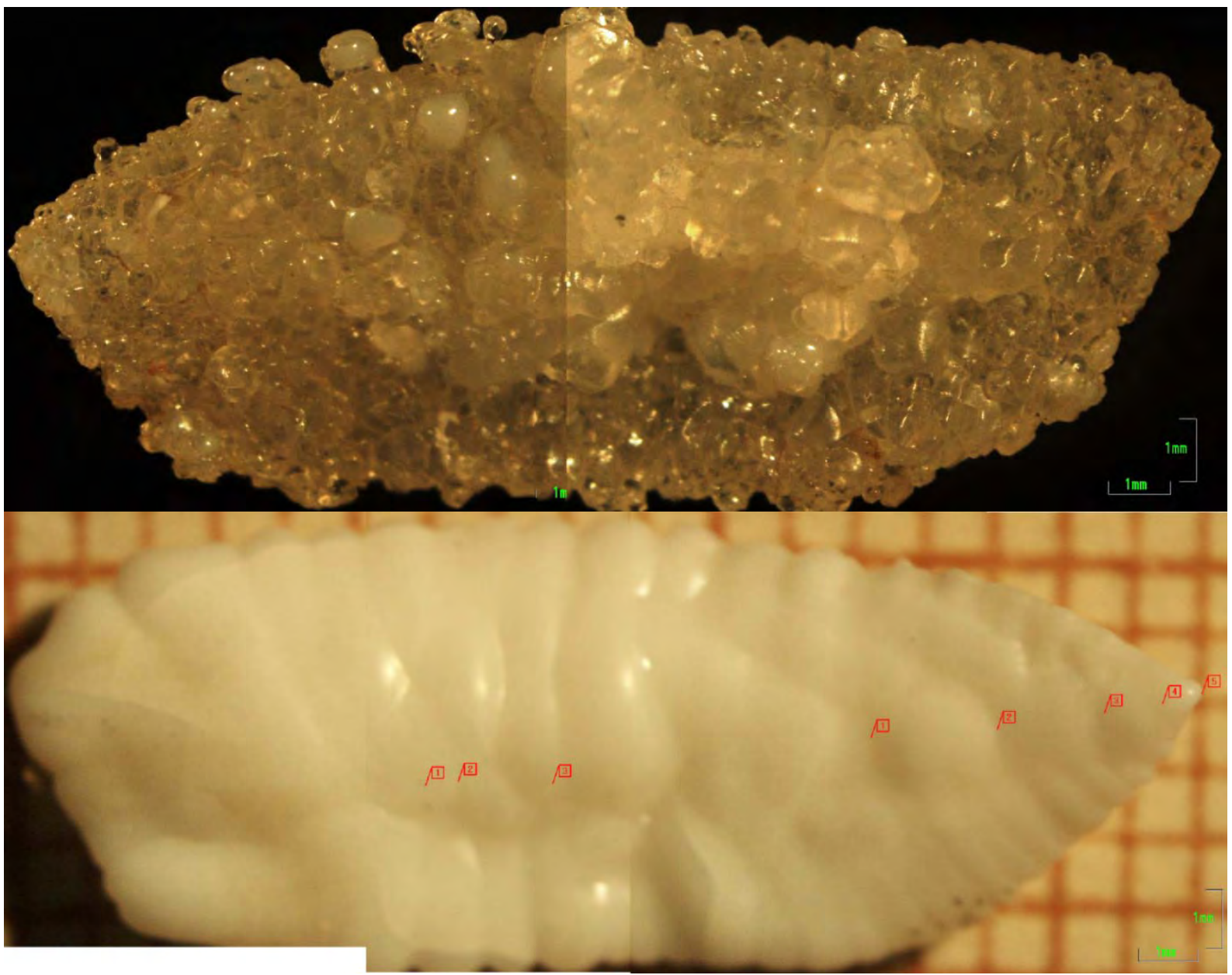

Fig. 50 Otoliths of haddock Melanogrammes aeglefinus from Barents sea: above with involutes with low level of proteins and below is normal.

Japan has much worse situation than Norway and other European countries. Since 1953, the fish and seafood of Japan seas were poisoned by mercury from chemical plant Minamata and Niigata. Peoples who eat them, especially fishing families were suffered the disease in 1784 of whom died and 10,000 people received compensation for the effects of the epidemic $[74,75]$. Up to 1970 , mercury was discharged by 2 chemical plants into adjacent seas and up to today, it widely bioaccumulated and biomagnificated within the marine environment. Its concentration in the products of sea fish and crabs were up to 10,000 times higher than in water, an organic compound (methyl mercury) that is toxic to living things. In addition, in March 2011, earthquake in Japan along with a huge tsunami caused a nuclear power plant failure and contamination of radioactive compounds [75]. Near Fukushima in 2 years after the crash caught of the fish, it was 254 thousand Becquerel of cesium per $\mathrm{kg}$ or even 2,500 times more radioactivity than the standard acceptability for human consumption. That indicates that it is still dangerous local seafood consumption [73]. Japan in addition as an islander of small islands has to have a great tradition in fishing for marine animals and has very high consumption rate.

Korea, being with Japan in front of the Japanese sea shares its pollution. The content of marine plants, have radioactive elements reached 130 thousand Becquerel per $\mathrm{kg}$, in fish such as trout: 18 thousand flounders 4.5 thousand Becquerel per $\mathrm{kg}$ [76]. Moreover, country suffers periodic famines leading to recorded cannibalism. The number of victims of these 
disasters ranged 3.5 million [73]. Strong toxic air pollution recorded in Seoul and Busan and Mercury in the air falling to the sea can exceed several times the pollution of water courses [77, 78].

Poland does not catch Antarctic fish since 1992. But consumption of fish in Poland is also very high. On the coast, millions of tourists, every day are traditionally relaxes on a fish fry after a stroll by the sea, and at the end of the stay buys a gift, smoked eel (which is on the red list not to consume). In addition, throughout the country in meatless Fridays fish are eaten almost in every catholic family.

Europe seas for Poland in respect to supply of fish are the same as for Norway already fishing fish in Antarctic. About the pollution of Baltic sea for twenty years writes continuously, so the fish that live in are hard to believe they suddenly become their deprived. Even if adults can eat Baltic fish without fear for young children and fetuses consumption contaminated food gives a much higher dose of mercury per $\mathrm{kg}$ of body [79]. It increases the dangerous if considering the risk from other sources of contaminations that exist in food, drinking water, air and in medicine treatment. In addition, reported Polish limits of fish consumption can be uncertain, because Polish data about bioaccumulation of toxins and their contents in the Baltic were very fragmented (as the Commission HELCOM was reported) [80].

In Poland, fishmeal is produced from fish caught in European waters that are contaminated. Almost all breeding animals, from fish, and cattle, poultry, ending the flock are fed by fishmeal [81]. In this case, not only the fish of the sea, but also breeding fish and even dairy products and meat can be a source of dangerous substances in the human diet.

About Baltic sea pollution, there are many writes, include threatens from sunk of leaking poison of gas stockpiles left after World War II [82]. Baltic marine environment was also heavily contaminated with mercury that lasts and lasts [78, 82]. In the 1960, in the Baltic states, a lot of plastics industry plants was operated, which were draining into the Baltic sea catchment mercury liquid waste resulting from the production of articles. In addition, the amount of mercury released into the environment by mining, metallurgy and heavy plant is approximately four times greater than the amount released in natural processes [81]. In addition to mercury pollution in the Baltic, there were discovered a high contamination of fish by DDT, PCBs and PCDFs, which all together were the source of poisoning of Swedes [83]. Swedish fishermen who fish in the Baltic sea had higher levels of toxins in the blood than fishermen in the North sea [83]. Such differences also relate to morbidity and underweight births [83]. With the impact of toxins on the offspring, the present generation is likely to suffer the effects of poisoning parents. Their fight against pollution had no support as it is now, in the current new technology with advanced methods of sewage treatment. It should be the source of the common opinion of the older generation, that the younger is less robust.

In Poland, the effect of diseases and illnesses happen everyday life and, unfortunately, is the reality of every Pole, $16 \%$ of them are registered by the Social Security, as a crippled and sick people. Former queue foods moved to the pharmacy and the clinic, prior to surgeries. Because of these queues, the paid number of medical visits in 2012 increased by 30\% compared to the previous year [84]. The average medical advice was 18 in German in 2008, and there were 45 patients a day per one doctor [85]. The huge demand for drugs that protect human and animal health and give survive from poisoning has extended their sale on grocery stores and kiosks. According to the report, the Chief Sanitary Inspectorate in 2014 in Poland has increased the number of bacterial food poisoning and infections [85]. One of the sources of them are fat fish. Direct danger to human from fish consumption exists from example from parasites Anisakid larvaes of Baltic cod (Gadus morhua). Those sea mammals parasites are living in human who 
eat cod not well prepared and also their allergens are danger even after thermal preparation [86]. In other hand, parasities could decrease stress of their host from living in pollutant environment [86]. Has new way adaptation of life to pollutant environment? Medications have become a valuable, highly desirable and articles of everyday purchases. Medicines such as "Omega 3 fatty acids" often exist in a healthy diet such as in Antarctic fish and often they were extract from fish, krill and microalgae to prepare the tablets, pastes and oil. It is a huge demand for different types of drugs and ways to combat various ailments and diseases. Life in disability and disease has become everyday life and, unfortunately, the reality in each family.

\subsection{Antarctic Krill and Fish, Comparison of the} Products

Krill, being used in medicine, as a new safe dietary supplement, a source of Omega 3 fatty acids, improving better than fish oil the functioning of the brain, strengthening the heart, improving condition of the hair, skin and liver is a desirable and profitable goal of catching in the Antarctic. Krill oil is obtained by the acetone extraction [87]. Krill protein and tissue and chitinous compounds are removed in the filtered extract, and the acetone and water are evaporated. The resulting olive packaged in 60 capsules of $500 \mathrm{mg}$ costs $\$ 40$ or 31.5 Euros. From krill, it is also produced the protein food in the fermentation process that imitate technology of digestion of whale of that species who ate krill (shrimp paste or sauce is produced where southeast Asian people reside). This process is simple, short and inexpensive and can be carried on the ship on freshly cached krill in the intervals between successive fishing periods, eliminating the costs of storage and transportation, and the cost of processing more difficult frozen krill [88].

The large profits from krill ensured by the pharmaceutical industry, of about $\$ 2,000$ per tonne (cost of krill fishing is $\$ 1,858$ per tonne, the catch price in the port is $\$ 3,833$ per ton) drive the high global catch of krill in the Antarctic and the abandonment less profitable catches of fish in Antarctic (Fig. 51) [18]. Fishing fish could get finance from krill industry (Fig. 52).

Fish: income from catches of fish in the Antarctic formerly was low due to the limitations of catch, and the high cost of fishing. Cost of fishing is about $\$ 1,062$ per tonne, while the fisherman in the port receive \$583-\$1,218 per tonne of fish, less for pelagic fish more for demersal [18].

In Poland, the fish are more desirable food than shrimp paste. Visual of fish is causing secretion of digestive juices, and appetite. However, the krill paste in Europeans often can cause indigestion. In addition, Antarctic fish also contain fatty acids Omega-3 and fish diet generally prolongs life, as it was seen in studies of Norwegian fishing families. "The Baltic fishermen had low mortality from coronary heart disease, and this low mortality may be associated with the positive aspects of fish intake" [83].

(1) Oil from small Antarctic fish, price for 200 capsules is $\$ 16-30$, combined with krill oil price of 30 capsules is $\$ 32-39$;

(2) Fish paste for human: $100 \mathrm{~g}$, cost $\$ 0.96$;

(3) Fish meat from the cleanest waters containing fatty acid Omega-3 in well natural proportion with meat. Price for fillets of the mackerel icefish is high: per one $\mathrm{kg}, \$ 15$.

Algae: Many species of microalgae together with diatoms occur in the seas around South Georgia Island, they are abundant there [89]. The warming trend at South Georgia Island is likely to promote phytoplankton growth [21]. Because of the limited availability of fish, microalgae, diatoms and brown algae provide alternative fatty acid source [65]. Fatty acids Omega-3 now produced from microalgae Schizochytrium sp. [65]. Oil algae contain acid DHA + EPA which first DHA (docosahexaenoic acid) is used in synthesis of neurotransmitters, second EPA (eicosapentaenoic acid) stimulates mainly the cardiovascular system by interfering with the 
synthesis of prostaglandins, prostacyclins, leukotrienes, thromboxanes [90]. Algae oil do not have smell and taste of fish and unlike to fish oil do not contain dioxins, PCB and heavy metals. Microalgal oils were more oxidatively stable than fish oil. Acids Omega-3 have better absorption and oxidative stability. Additionally, algal caretenoids guard the oil against oxidation [91]. Price of algal oil: for 30 capsules is $\$ 10.2$. One capsule contain $250 \mathrm{mg}$ of DHA + EPA (187.5 mg DHA \& $62.5 \mathrm{mg}$ EPA).

Algae are also treat as an alternate food source for human (Spirulina blue green alga and Chlorella green alga), some algae are consumed as fresh, dried and cooked and algae farms have been spreading rapidly. Use algae as life food source in commercial mollusc, fish and crustaceans cultures have now become very common. Aquaculture is now one of the most rapidly growing line of food production. Many marina algal species have been gathered for use as fertilizers, several ones contain growth hormones, immunity factors against crop disease, they have nitrogen fixation ability that increases rice yield. They contribute fast seed germination increased growth and fruit yield. Microalgae, recognised as one of the most promising biofuel source, reduce dependence on fossil fuels. Microalgae with biodiesel production could improve wastewater treatment [92].

South Georgia Island has also large algae, giant kelp that reaches $40 \mathrm{~m}$ in length and provides home for many species of immature fish and invertebrates. There are possibility to install macroalgae cultivation rig for offshore cultivation macroalgae by including the basic principles of long line fisheries and massel aquaculture in its design. The structure has proven capability to withstand energetic waves 6 meters and storms. Obtained yield was 12 kilos per meter [93].

\subsection{Single Species Catch}

Economic works since a long time indicated that leaving possibility of choice from various type of fishing, lead to single-species fisheries directed to most profitable catches, what cause the destruction of living resources [94, 95]. High profits from krill, dollars 2,000 $\mathrm{t}^{-1}$ increase the catch of krill from year to year, while fishing need to subsidize diminish and exploitation of living resources in Antarctica from economic reasons, single-species focused only on high profitable catch for krill (e.g. Poland caught only krill). The decline of fish stocks and other krill eating animals accompanying to increase of krill catch, indicates that stocks of krill in the Antarctic should have a higher density of biomass in order to solve the role of base food for fish, cephalopods, penguins, birds, seals and whales. In addition, greater density of krill reduce pressure predation on fish, reduce competition for food, and increase the protection, survive and spread possibility for larvae of fish species associated with krill aggregations.

Despite the many regulations, there is still competition between fishers of CCAMLR zone. For each stimulus act, dictatorships: "first take" profits, currently from krill before it could be caught by any other competitor. Instead that, "krill showed a significant decrease across the whole SW Atlantic sector during the period 1976-2003", "there are declining habitat suitability for Euphausia superba", biomass krill depended icefish is highly reduced, krill fishery reduce icefish larvae and CCAMLR fishers still catch krill too (Fig. 7) [6, 10, 18, 21]. Krill fishery removed 180-360 thousand tons per year base food of Antarctic fish in the Atlantic sector of Antarctic. Current profits were a few expensive oil' jars. Current lose is the great amount waste from production krill oil, threw to the sea. That waste had enormous ecological value when was a live: supporting hatchery for larvaes, changing chemical water, as a base food and the roads for life migration across extremely cold watery deserts.

\subsection{Competitions for Profits}

The competition and pursuit of financial profit has 
been operating since the beginning of the exploitation of living resources in Antarctica. Seals were hunted for their pelts and by 1825 , close to extinction. After that, sealers began hunting elephant seals and penguins for their oil.

Next were large predators, whales-maximal fishing focused because they have a higher value, providing more economic profit per unit of expenditure on fishing than smaller whales or fish or krill. Race to maximize profits from the catch focused them exclusively on whaling in the greatest weight. This led to depletion of subsequent whale species (Figs. 53-62). At the beginning, in the years 1910-1913, Humpback and Right Wales were over caught (Fig. 54). They were easy to hunt. Humpbacks are slow swimmers allows whalers to get close and they often collect in groups near to land and draw attention by their behaviour, easy to observe. The names of rights were given to species of the early whalers because they were the "right" whales to kill. They have large amounts of oil, blubber and baleen or whalebone, they are slow swimming (easy to catch) and float when killed. Next Blue and Fin whales were hunted as their big bodies over $100 \mathrm{t}$ per Blue individual, and $50 \mathrm{t}$ per Fin gave the greatest profits. The circulatory system of Blue pumps $10 \mathrm{t}$ of blood through the body. When their stock dropped (blue whales were nearly extirpated then) the most difficult Sei, after Sperm whales were hunted in the greatest amount from 1970s.

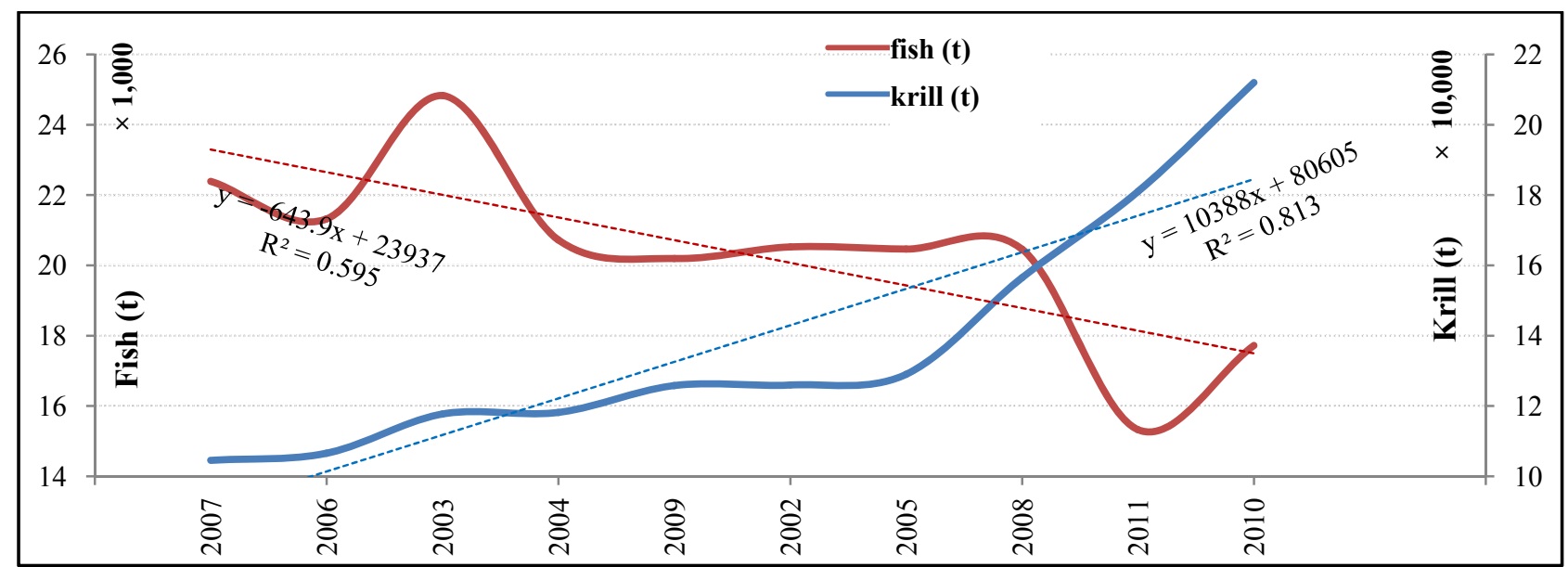

Fig. 51 Marked decline in fishing fish while increasing krill fishery.

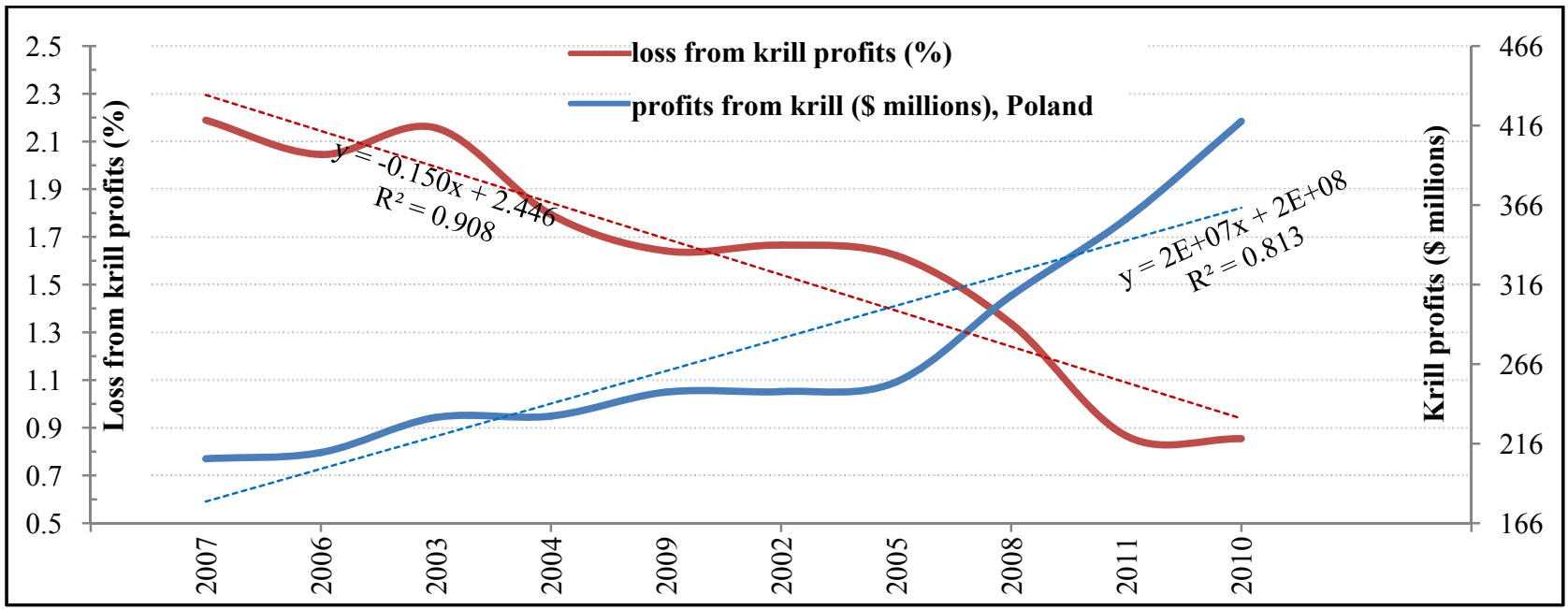

Fig. 52 Big catches of krill in the Antarctic are giving very high incomes, enough high in order to finance fishing of Antarctic fish, constituting a little per cent of profits obtained from sales of the krill. 


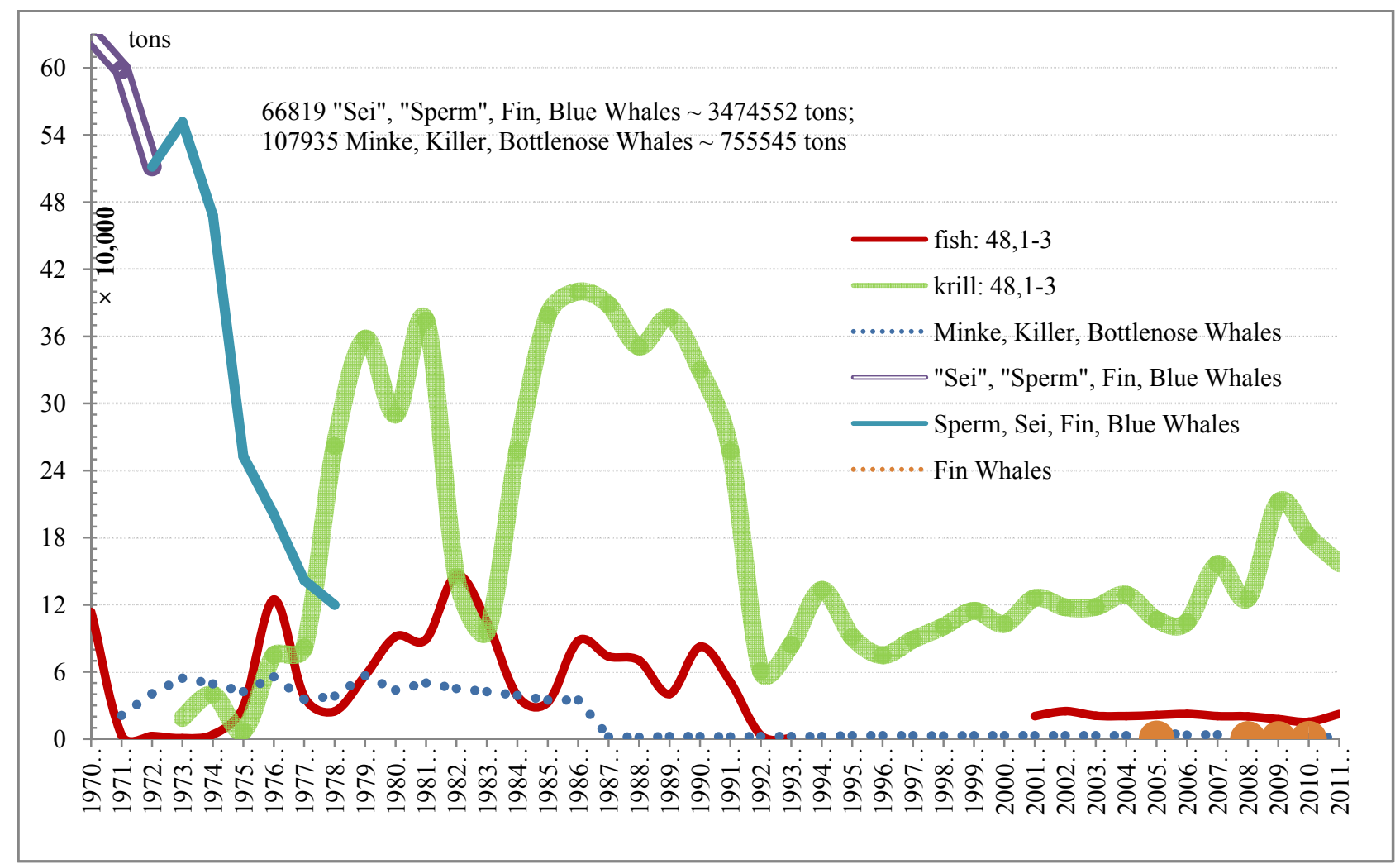

Fig. 53 Whales, fish and krill catches in Antarctica [96, 97].

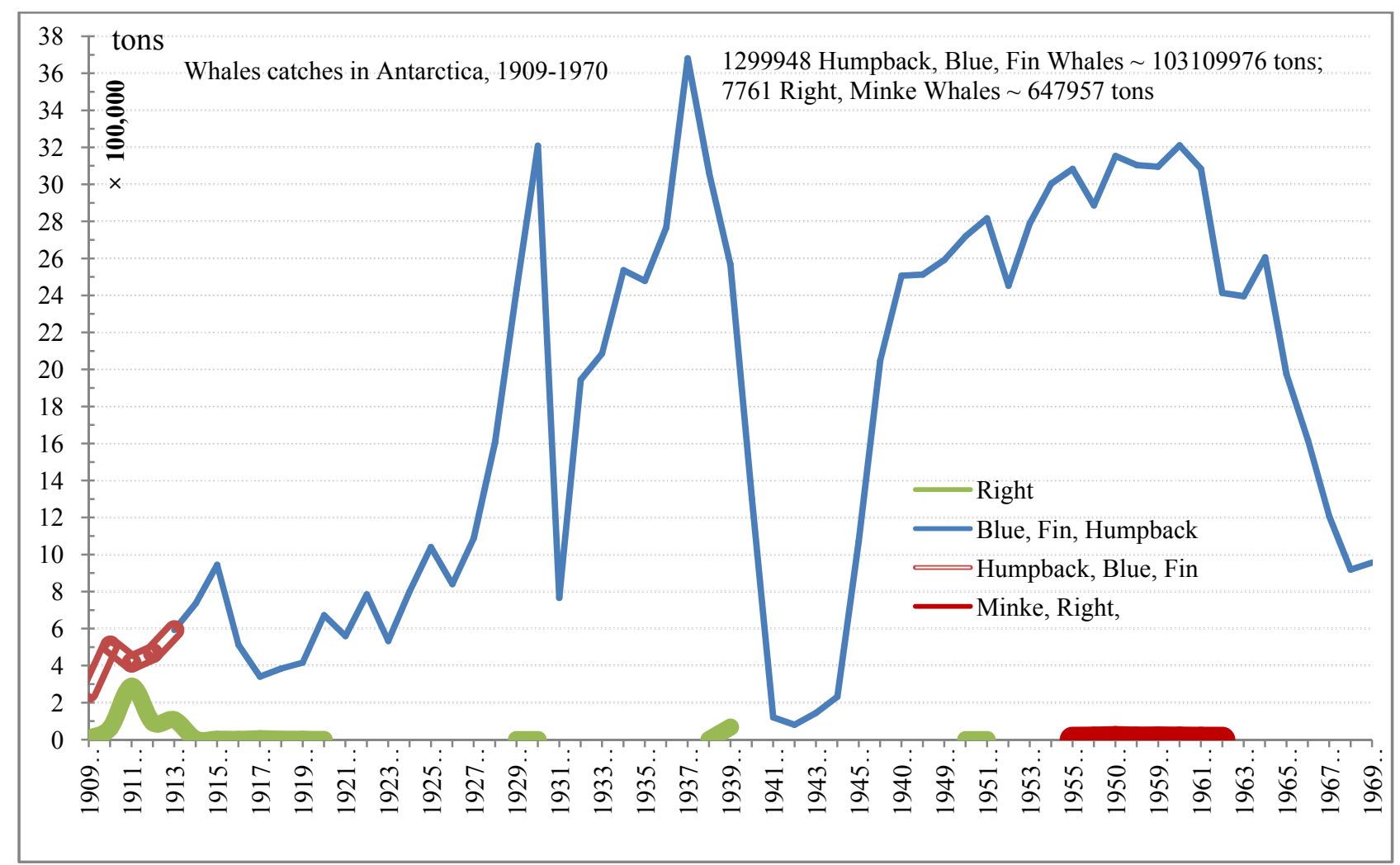

Fig. 54 Whales catch in Antarctica [96, 97]. 
Sei whales are among the more elusive of the larger whales, not coming very close to land at any time and not forming large groups or "schools". Sperm whales are difficult to catch, because they are the deepest, up to depth of $1.5 \mathrm{~km}$, and longest of all whale divers (catching giant squid in the dark ocean depths). At the end, even Minke numbers previously quite healthy due to whalers concentrating on larger, more profitable species dramatically dropped as they hunted from 1970 by all whalers and are now hunted for scientific reasons. Minks weight $7 \mathrm{t}$, and are ones of the smallest filter feeding whales.

Before 1970, when krill was not caught, $103,757,933 \mathrm{t}$ of whales were taken. In 1970, it still caught $600,000 \mathrm{t}$ of large whales and 120,000 $\mathrm{t}$ of fish. In compare to today in 2012, the catches were only $22,000 \mathrm{t}$ of fish. After the disappearance of whales fishing turned to catching on species array of fish from large commercial bottom ones to small pelagic and little later on krill in high rate, repeating above circle of competition for high profit. In result, the fish stocks declined what is displayed in low catch depended on stock. In 1977/1978 13,015 t of fish Pseudochaenichthys georgianus were caught, but in 2011/2012, 0 t. Similarly, catch of Chaenocephalus aceratus drop from 2,000 t to $0 \mathrm{t}$. Both species as large bottom should be in bycatch. But they were as a direct species in Antarctic fishery because of the behaviour of fisheries for catching more valuable large bottom than pelagic direct icefish Champsocephalus gunnari. Because of that commercial fishing were lead on north east sides of shelf South Georgia Island where large Pseudochaenichthys georgianus dominated (Figs. 2, 29, 39 and 40). Fisheries which were not fishing on west were direct fish but smaller Champsocephalus gunnari was more numerous. Even fishing of smaller icefish Champsocephalus gunnari, their caught fell from 8,000 tonnes to 11 tonnes. They were accounted for $50 \%$ of the catch, now only for $1 \%$.

Catch of krill, pelagic small fish and seafood, although having initially small profit, as being at the

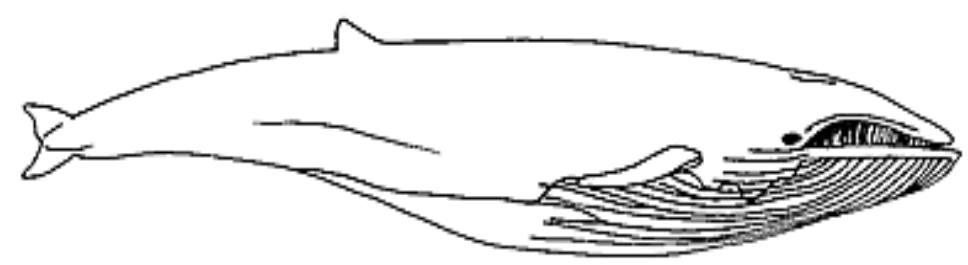

Fig. 55 Fin whale, Balaenoptera physalus.

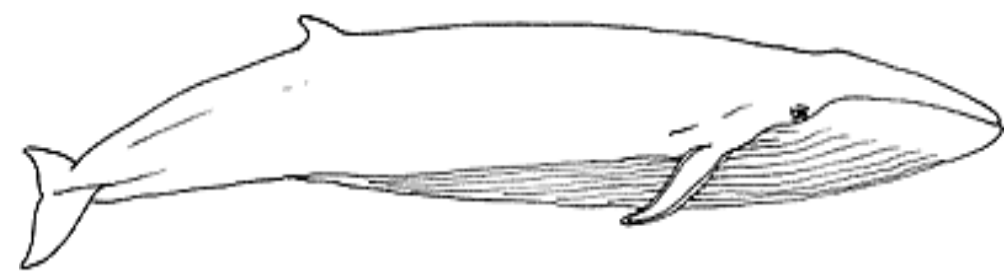

Fig. 56 Blue whale-sulphur bottom whale-Sibbald's rorqual, Balaenoptera musculus.

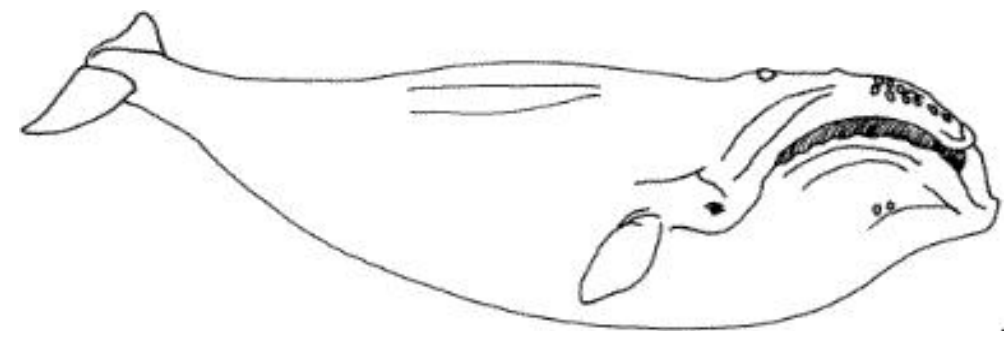

Fig. 57 Southern right whale, Balaena glacialis. 


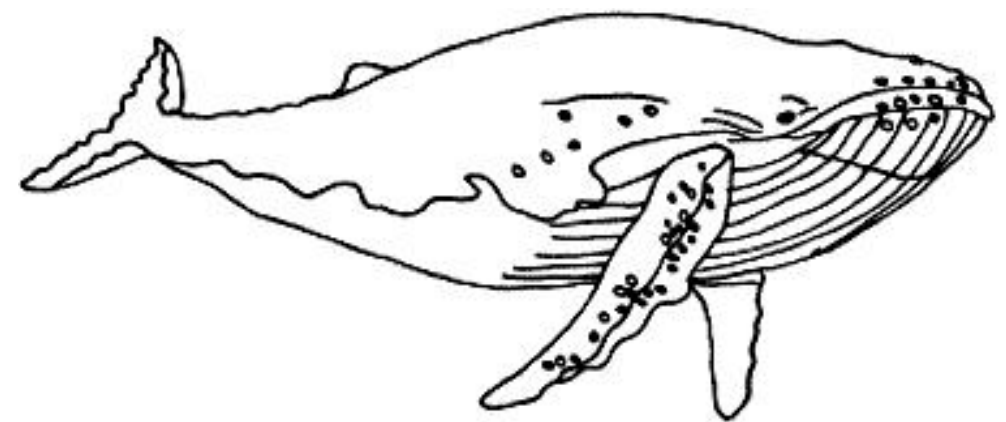

Fig. 58 Humpback whale, Megaptera novaeangliae.

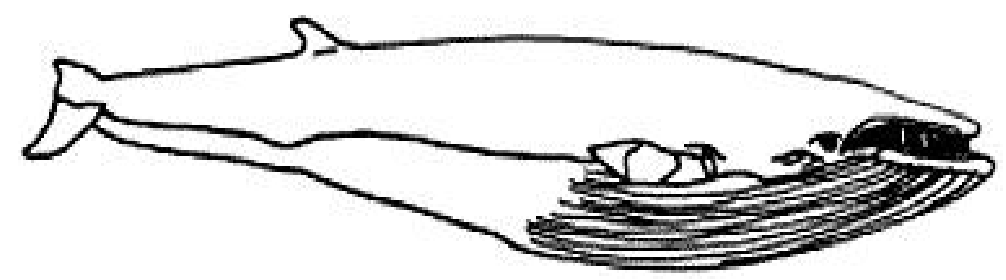

Fig. 59 Minke whale, Balaenoptera acutorostrata.

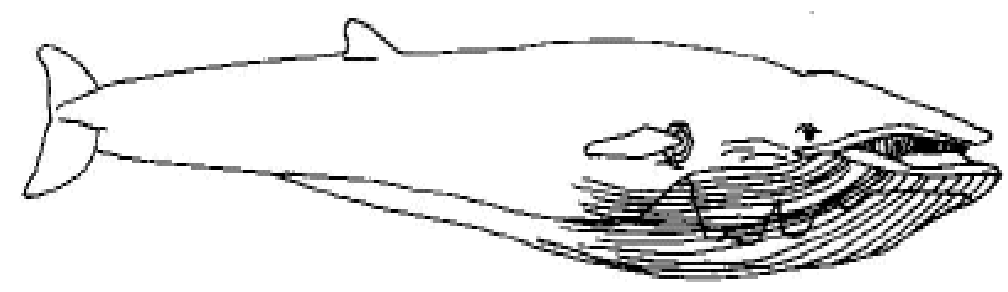

Fig. 60 Sei whale, Balaenoptera borealis.

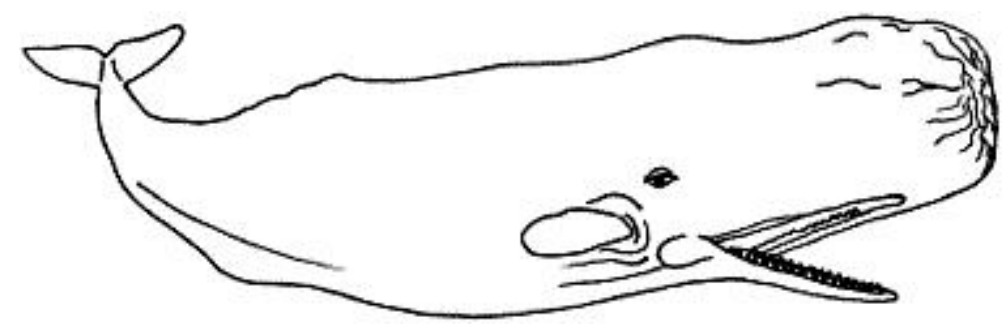

Fig. 61 Sperm whale, Physeter macrocephalus.

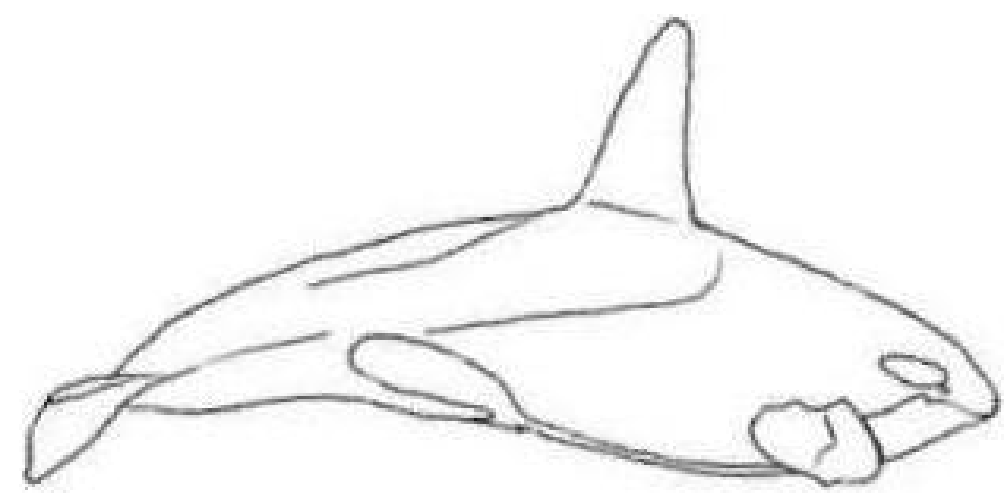

Fig. 62 Killer whale, Orcinus orca. 
base of the food ladder has very large biomass. So, the fishing industry currently focused exclusively on krill that guaranteed steady and long-term income. But additionally, when new processing technologies of krill and its use in medicine had substantially increased the value of krill, its catching was doubled. In the same time, a suspension of recovery of fish and whales were often stated, supposed to lack of krill. The krill, when its main food was not in appropriate density, it was not in well availability in the huge space in which small numbers simply disappear. Krill, in order to be as a food in the needed place, time and proper form-stage of development, it should not only be there, but there also should occur in high densities characteristic, and expected from all organisms being in the base of the food chain. This is particularly important in harsh Antarctic ocean, whose water contains high densities of krill is more friendly to colonize by the larvae of fish and older ones. Concentrations of krill, not only by itself ensure food for fish larvaes, but also increase their survive, by changing the physic-chemical properties of water inside the clusters of krill. Krill aggregations by migration in the water, make them move and exchange, oxygenated them, activates suspended and dissolved compounds, raises their temperatures.

Because of the high profits, 1975 \$ per one $t$ of krill obtained in the port, from 1974, between $120,000 \mathrm{t}$ to $320,000 \mathrm{t}$ of krill were fished out per year.

Fishing industry driven by the competition and the pursuit of high profits holds a one-way fishing at high level directed to krill. This exploitation way has short period into the future as it is based on the early advantage from large catches. It is not taken into account declining the habitat suitability for Euphausia superba: large warming about $1.54{ }^{\circ} \mathrm{C}$ of surface water around South Georgia Island which has a significant negative relationship with mean summer density of it [21]. Krill growth faster at colder water (about $0.5^{\circ} \mathrm{C}$ ) as it is inhabitant of cold waters of the seasonal sea, ice zone that typically are not in the summer at South Georgia Island. That warming trend is likely to promote phytoplankton growth [21].

\subsection{Global Approach}

In addition, although fishery planning is very advanced for particular species, in normal averaged relationship, it do not take into account frequent catastrophic events: southern strong winds, global warming and made by human. Their consequences generating catastrophic changes in species appearing are still continue. Often, fish biomass changes do not take into account high level of whaling that had great influence on Antarctic ecosystem. Removal of 3,647 whales before 1909 and then 1.2 million whales (krill predators) increased krill biomass, and also biomass of krill consumers, including fish and fish predators: birds, penguins and seals. Removal of fish-eating whales further increased number of the fish. Similarly, during stock assessment survey, one haul has large catch that high biomass of fish as normal for population. During cruise of FSA, there were extremely large catch of Champsocephalus gunnari not explained from what reason, but it could be migration determined by every year catching and or use sonar detection.

One successful international resolved problem is whale protection against struggles for profits. The only Japan catch whale now for science porpose to study the case that component of food from whales reduce mercury contamination. In 1960s and 1970s, when seafood of Japan seas were poisoned by mercury, whale meat supplied $30 \%$ of the daily intake of protein in Japan and support school in nutrition program. It is one positive whaling in Antarctica, not taking into account other countries that perform whaling to get the high profits from the baleen.

Japan, Norway and Iceland cover high demand on sea food, have great reason to fishing in Antarctic clean waters. The countries having another opportunity in supply not contaminated food should offer that opportunity to other CCAMLR members, 
which will save Antarctic living resources before continuing persisted overexploitations.

\section{Discusion}

Changes in the aquatic environment as a result of global warming contributes to changes in the species composition and structure of fish populations inhabiting them, as there are biogeographical provinces divided the southern ocean. But those changes are long time scale, and mackerel and other icefish, which distributed in great circum polar current have inflow of its cold water from the south. Instead of that, the systematic decline in the biomass of icefish caught in the shelf of South Georgia Island appears to be correlated with several causes, which all together overwhelm species. Limited food resources consisted krill being less numerous, by-catching fish larvae in krill fishery, higher predator's pressure in years of low density of krill, catching fish before obtain success from spawning [10, 20, 21]. When icefish larvae have pelagic life periods, they were catch by pelagic fishery (Fig. 4). Additionally, there are lack of ice cover offering crevices to hide.

These drive Antarctic lives to observed drop in their stock. While in 1970, there were over $600,000 \mathrm{t}$ of large whales and 120,000 $\mathrm{t}$ of fish, in 2012, there were $2,000 \mathrm{t}$ of that fish. In the past in 1976, as numbers of whales disappear, fish and krill were cached in great amount in a period 1978-1992. Soon after that, fish stocks fall and they had to be limited to catch from 1992. During next 20 years, fish biomass was not recovered to the level of giving constant catch.

Probably, intensive catching in summers determine fish to migrate into regions that have less food but is better for survive. It could be an adaptive behaviour in response to seasonal changes in predation and growth, to minimise the ratio between predation mortality and growth rate. Individual fish change their migration strategies to optimise the cost/benefit in migration response [46].

In order to have the rebirth of fish stocks, a good solution should be find, which will protect living resources of the Antarctic more efficiently than previously. Probably, the best solution would be for saving Antarctic life in situation of global warming that generate, support blooms of phytoplankton is undertake Antarctic algae farms. It is great alternative food resource for human and animal [65, 92]. It will stop the process of krill degradation. Large parts of krill stock are discarded and irretrievably wasted, then a life constitute a huge valuable biomass for the entire living world of Antarctica. It will increase biomass of icefish, that save toothfish. Currently, for a couple of jars of krill concentrate, the basis for the functioning of all animals is destroyed, ranging from whales and ending on cephalopods and larval forms of fish.

In the current time, animals are more needed from a higher rung of the food ladder, which can be used completely without waste: meat for consumption and the remainder on meal and oil.

In accordance with the obligation to protect the living resources of Antarctica, Scientific Committee of the Commission for the Conservation of Antarctic Marine Living Resources (SCCCAMLR) may determine condition on which krill will be allowing to catch: such as good result for biomass of sentinel fish, which feed on krill, such as Pseudochaenichthys georgianus. Inability to catch or destruction of their resources would result in total loss of limit of krill catch. Study of fish biomass by the ship catching krill is possible in non-invasively way using sonar for the detection of krill clusters and requires little financial effort, only implementation of the existing manual for estimating fish biomass by echo integration [98-100].

Knowledge of biomass of the fish would be an important in determining not only fish but krill catches too.

Now that the icefish stocks, such as Pseudochaenichthys georgianus in the Antarctic has not regenerated, catch of krill if not replaced by algae farms should be reduced at half, at a level which Pseudochaenichthys georgianus resources will tend to 
increase as it was in season 2004/2005 (Fig. 51). Derogation from the maximization of profit (Fig. 52) will be rewarded by full revival of Antarctic living resources and renew the ability to catch icefish.

But the total change from krill harvesting to algae farms would be giant step toward revival and increase fishing possibility of the victory of the human over the competition law "first take all profit from the exploitation of living resources".

There is a suggestion for exchange krill fishing on Antarctic algae farms to obtain possibility for catching the fish, at a level to not overfishing them, just to have healthy food in the world by human heavily contaminated. Catch krill is depriving the fish not only food but additionally friendly environment for the development of the larvae, which is a kind of home. Each creature has a shelter, mink, bushes and here for fish larvae are krill bushes. And at last, fishing krill will deprive of human young population large reservoir source of food and living nature.

Reducing the amount of catch of krill will increase the later profit. Partial withdrawal from profits obtained from krill oil in favour of catching of fish increase further profit because of conservation of fish. It will retain fish larvae living in krill aggregations, also the great numbers of krill will be a food available to fish and also there will be a wider range of products from Antarctic sources.

Transfer the limits of catch of krill to dependency from the biomass of fish. This time, for high risk from the poisons in the food, delivery of Antarctic food on a marked can decrease that risk. First order is to have good food, because in that case medicine will not be need. It is better to have Antarctic fish than krill oil. Unfortunately, the possibilities of obtaining Antarctic fish reduce in any case the high catch of krill, from which only a small part of it is useful for a man. The huge part of the mass of krill is irrevocably discarded and wasted in the process of separating of chitin compounds in the production of krill oil and paste. Otherwise, being left in nature, this part would be transformed in the Antarctic food chain and processed into form of protein of fish or crabs easily accessible to humans and other consumers of fish. A couple of jars of krill oil destroy the basis for the functioning of all animals Antarctic: starting from small larval forms of fish and ending on large whales.

To catch more fish on the shelf of South Georgia Island and thus reduce the risk of mercury poisoning by eating fish, the countries before benefiting from the catch of krill first should provided a proof that the stocks of krill eating fish is in a good state. Knowledge of these fish biomass would be fundamental in determining the size of the catch of krill. This means when the biomass of krill depended fish, such as Pseudochaenichthys georgianus, which is very small, the catch of krill should be much reduced.

Increase of the size of fish biomass would be in the interests of the exploiters of krill and would guarantee the protection of fish. It would prevent eliminate the richness of Antarctic fish. Similar relationship was in high exploitation of tropical shrimp that led to the disappearance the richness of fish fauna in other oceans [54].

Countries-explorers, who only been catching krill because they do not fishing did not know their status, did not see a direct link the increased use of krill with long period of absence in the rebirth of the state of fish biomass. From a time of large fishery for icefish, there were many works indicate that krill is a base food for them. Because of that profits derived from the high catches of krill is short, it cause the loss of fish stock, that regulate the entire ecosystem. There is even a reverse sentence based only on knowledge as there is large biomass of krill, then it could be caught a lot, much more than it is now. But it is wrong sentence, because it should be a lot of krill in that greater amount which is sufficient not only for the survival of the species, but also for existing of the Antarctic ecosystem. This opinion shows the needs to put the study of fish biomass to krill explorers. 


\section{Conclusions}

(1) Pseudochaenichthys georgianus since 1970 in the trawl fishery around South Georgia Island, with the principal target for mackerel icefish formed a substantial, unreported regular bycatch [10]. Tactics for achieving the first major profits from resources was leads species to elimination. Biomass estimates indicated a logaritmic decline (Tables 3 and 6, Figs. 14 and 15) in $75 \%$ from the pre-exploitation stock levels of the early 1970s [10]. In the tactics of the commercial vessel to get the highest profits, Antarctic fisheries were caught more valuable large bottom Pseudochaenichthys georgianus and Chaenocephalus aceratus than pelagic Champsocephalus gunnari direct, but smaller than above icefish (Fig. 63) [6]. Additionally, study of very small Myctophidae was a little, at the end, even was abandoned by the fisheries [17].

The commercial hauls for direct species smaller fish Champsocephalus gunnari were not lead on western side where Champsocephalus gunnari dominated (even with 22 tonnes in single hauls) [6, 20]. They were leaded on north east sides of shelf South Georgia Island where large Pseudochaenichthys georgianus from bycatch dominated (Figs. 2, 29, 39 and 40).

(2) The biomass estimated for 40 years in spide of trend of decline, have one of the largest components, the periodic oscillation. Periodic model best (the smallest squared differences) explain repeated large biomass fluctuations in the years 1975 to 1981 with amplitudes $\pm 15 \times 10^{3}$ tonnes around average $20 \times 10^{3}$ tonnes that further up to 2005 season decline to oscillation around average $5 \times 10^{3}$ tonnes with $\pm 4 \times$ $10^{3}$ t. Fitted model reveal periods of 3-4 years and predict for 2014-2016, little increase of the biomass oscillation at level of $8 \times 10^{3} \mathrm{t}$ with reduced amplitude of $2 \times 10^{3} \mathrm{t}$. That predictions is in well agreement with slowly increase density of adult fish that were reported for target similar and close related mackerel icefish [20]. This is because the current fishery are localised in pelagic waters on south western shelf, outside of north

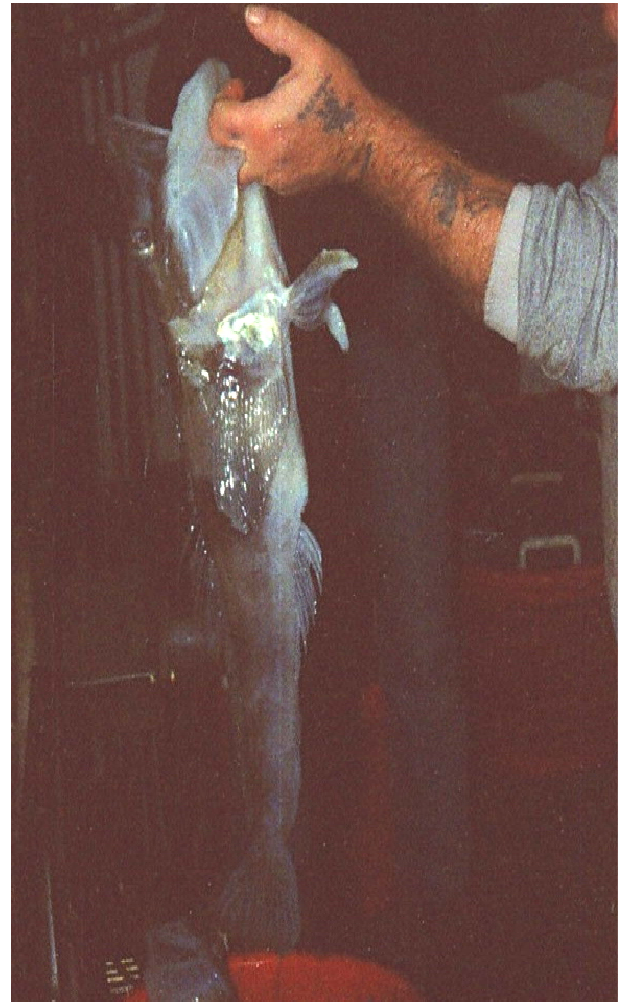

Fig. 63 Bycatch of $60 \mathrm{~cm}$ Chaenocephalus aceratus and Pseudochaenichthys georgianus [17].

east area with high density of older icefish. In the contrary in north east area, the worming with around $1.5^{\circ} \mathrm{C}$ have negative influence on growth of krill, with increased large krill fishery diminish the food availability for icefish there (Fig. 7) [21]. The oscillation of Pseudochaenichthys georgianus biomass in 3 yearly sequences could be seen in published biomass data for 13 years from 1986 to $2006\left(1 \times 10^{3}\right.$ tonnes): ... 5.3 オ 12.7 オ 16.5 У 8.8 オ 14.9 オ 16 У 8.9; 8.6 У 4.7 オ 9.4 オ 10 У 3 オ 9.2 [10].

Additional reference for biomass levels is a valuable for reduce the risk of depletion when biomass levels are estimated to be very low, as it is for Pseudochaenichthys georgianus with pointed for biomass in $75 \%$ declined $[9,10]$.

(3) The three yearly periodicity of biomass oscillation could be explained by species life cycle and fishery influence. In 1970 s up to $1984 / 1985$, species had 0 fishing mortality until it achieved $40 \mathrm{~cm}$ TL, when it is 2 or 3 years (Fig. 18). This produce large biomass living in the sea, because for each $7 \mathrm{~cm}, 3$ 
gram postlarvae after 3 years body mass increase with about $1 \mathrm{~kg}$ and for thousand, $1 \mathrm{t}$. That fish migrate inshore for spawning at fishing area in north east shelf of South Georgia Island [10]. Large fishery there (about $13 \times 10^{3} \mathrm{t} \cdot \mathrm{y}^{-1}$ of adult) reduce adult fish biomass on low level. Low level persisted until new hatched cohort, if strong after three year of growth of body will arise the biomass on high level. That three-four years life cycle display in 3 yearly fluctuations of biomass because there are events of strong cohort (Fig. 18). When that cohort of numerous fish is at age of 3 and 4 (having large and heavy body), it determine years of high level of biomass. When that cohort is at age of 1 and 2 (juvenile with small body mass), it indicate years of low level of biomass, because parallel cohorts of older fish were weak. Appearance of strong and weak cohorts accompany anomaly warm and cold years, that have influence on species success in spawning, larval development, food availability (sea ice cover) [21]. Weak cohorts could be related with skip spawning (not all adults spawn every year, having follicular degenerative process) [51]. Strong cohorts, large dominate of one age group in the year, biomass periodicity of icefish could be recognized in published data for Pseudochaenichthys georgianus and Champsocephalus gunnari (Fig. 8) [6, 10].

(4) Age group and cohorts in fish samples without otolith were discovered from length frequency. The best identify and separated age from length frequency for older groups over $40 \mathrm{~cm}$ (Figs. 19 and 20) were achieved by extend the Bhattacharya method [8]. Set of four or five normal distributions of older fish obtained by Bhattacharya method were fit to the overall length frequency (known basic identifying age data) by procedure of minimizing of the squared differences of "Solver", that search and select parameters appropriate to shape of profile of length frequency [101]. With this extend exact fish numbers and additionally negative growth could be included in regard to large bone desorption that were discovered for icefish [102].

(5) Periodicity of total mortality discovered for icefish Pseudochaenichthys georgianus show species dependence from oscillation of anomaly temperature. Anomaly cold season 1981/1982 cause delayed and low primary production, less food, so increase mortality of all SG icefish (Figs. 37 and 38) [21]. Anomalously warmer season 1985/1986 decrease growth of krill, so increase mortality of adult SG icefish, but is more productive and because of decrease mortality of younger SG icefish, living below $200 \mathrm{~m}$, where warming temperature was not evident (Figs. 37 and 41) [21]. Mortality of mesozooplankton (fish larvae) embryonic development depend on temperature [21].

(6) Large biomass fluctuation reported for Champsocephalus gunnari probably is close to fluctuations and periodicity of Pseudochaenichthys georgianus and should be explain by similar periodic function, because a part of similar fluctuations, their migration distributions indicate comparable life history strategies around South Georgia Island, their ecological roles are close related, and have similar growth strategy (Figs. 8 and 10) [10, 15]. Their growths are depending on krill availability as a food. This confirms similar periodicities that were discovered 88 years ago in whale's catches [52]. There were years abundant in blue whales (Balaenoptera musculus): 1924-1925, 1926-1928 switched with high catches of less profitable fin whales (Balaenoptera physalus): 1925-1926, 1928-1930, because of scarce of blue whales. That periodicity were linked to local both food availability and oceanographic conditions in which fin whales years can be identified as seasons with low krill availability at South Georgia Island [52]. They were also discovered in age structures of krill, that 3 years cycle of recruitments failure equilibrates to large oscillations of krill biomass between minimum level $33 \%$ and maximum $91 \%$ of normal population level [52].

(7) The resources of Champsocephalus gunnari and Pseudochaenichthys georgianus are based on the age structure of 0-4 (or even up to 7+) years (Figs. 8 and 
21) [6]. The same model of age structure applied to fluctuations in krill biomass explained large of them by a 3 years cycle scarcely [52]. That science investigation display: biomass fluctuations of Champsocephalus gunnari from 34,818 tonnes in 1992 to 106,548 tonnes in 2013 as are from $10 \%$ to $31 \%$ of normal population level $(10 \times 34,818$ tonnes $)$, which can additionally inform on several 3 years cycle of failure in species recruitment $[6,20]$. Maintain by deterioration of the environment for krill at South Georgia Island [21]. Which mean reducing the availability of food for larvae, young and adult icefish. Krill consist about $99 \%$ of food of Champsocephalus gunnari (Fig. 16).

(8) Replace krill fishery by the Antarctic algae farms will restore icefish biomass, enlarge catches of toothfish and start use of global warming effects for human needs. Warming trend is likely to promote phytoplankton growth at north east of South Georgia Island [21].

\section{References}

[1] Bleasel, I. E., Bolin, B., Knox, G. A., Bonner, W. N. 1990. "Waste Removal in Antarctic, Experts Team Report of Science Committee Antarctic Research in the Matter of Waste Removal." Polish Polar Research 11 (1-2): 173-205.

[2] Meyer-Rochow, V. B. 1999. "Coming to Grips with a Slippery Issue: Human Waste Disposal in Cold Climates." International Journal of Circumpolar Health 58: 57-62.

[3] Emnet, P. 2009. Heavy Metals: A Heavy Burden on the Icy Continent. Graduate Certificate reports.

[4] Dommergue, A., Sprovieri, F., Pirrone, N., Ebinghaus, R., Brooks, S., and Courteaud, J. et al. 2010. "Overview of Mercury Measurements in the Antarctic Troposphere." Atmospheric Chemistry and Physics 10 (4): 3309-3319.

[5] Bargagli, R., Agnorelli, C., Borghini, F., and Monaci, F. 2005. "Enhanced Deposition and Bioaccumulation of Mercury in Antarctic Terrestrial Ecosystems Facing a Coastal Polynya." Environment Science Technology 39 (21): 8150-8155.

[6] Sosiński, J., and Paciorkowski, A. 1993. "State of Mackerel Icefish (Champsocephalus gunnari Lonnberg, 1905) Stock from South Georgia Area Based on Polish Biological Investigations in 1975-1992." Polish Polar Research 14 (4): 407-431.
[7] CCAMLR. 2012. "History." Accessed July 13, 2012. https://www.ccamlr.org/en/organisation/history.

[8] Sparre, P., and Vanema, S. C. 1982. Introduction to Tropical Fish Stock Assessment. Rome: FAO Fish Techn. Paper.

[9] CCAMLR. 2013. Fish Stock Assessment. Report of the Working Group.

[10] Clarke, S., Reid, W. D. K., Collins, M. A., and Belchier, M. 2008. "Biology and Distribution of South Georgia Icefish (Pseudochaenichthys georgianus) around South Georgia and Shag Rocks." Antarctic Science 20 (4): 343-353.

[11] Mucha, M. 1980. "Characteristics of South Georgia Icefish (Pseudochaenichthys georgianus, Norman) from the Region of South Georgia Island (Antarctic) in the Years 1977-1979." Polish Polar Research 1 (4): 163-172.

[12] Parkes, G., Everson, I., Anderson, J., Cielniaszek, Z., Szlakowski, J., and Traczyk, R. J. 1990. Report of the UK/Polish Fish Stock Assessment Survey around South Georgia in January 1990. Research Report for the Meeting of Working Group of FSA CCAMLR.

[13] Jones, C. D., Kock, K. H., and Balguerias, E. 2000. "Changes in Biomass of Eight Species of Finfish around the South Orkney Islands (Subarea 48.2) from Three Bottom Trawl Surveys." CCAMLR Science 7 (1): 53-74.

[14] Jones, C., Damerau, M., Deitrich, K., Driscoll, R., Kock, K. H., and Kuhn, K. et al. 2009. Demersal Finfish Survey of the South Orkney Islands. AMLR 2008/2009 Field Season report.

[15] Traczyk, R. J. 2015. “Age, Growth and Distribution of the Antarctic Fish Pseudochaenichthys georgianus Based on Otolith Morphometry." Journal of Environmental of Science and Engineering B 4 (2): 53-102.

[16] Everson, I., and Campbell, S. 1990. "Areas of Seabed within CCAMLR Subarea 48.3, South Georgia." In CCAMLR Selected Scientific Papers, 459-466.

[17] Traczyk, R. 2014. Memories from Antarctic Expeditions of the National Marine Fisheries Research Institute. Kraków: InAltum.

[18] Sumaila, R., Marsden, A. D., Watson, R., and Pauly, D. 2007. "A Global Ex-vessel Fish Price Database: Construction and Applications." Journal of Bioeconomics 9: 39-51.

[19] Lam, V. W. Y., Sumaila, U. R., Dyck, A., Pauly, D., and Watson, R. 2011. "Construction and First Applications of a Global Cost of Fishing Database." ICES Journal of Marine Science 68 (9): 1996-2004.

[20] CCAMLR. 2015. Fishery Report 2014: Champsocephalus gunnari South Georgia (Subarea 48.3). Report from Catches at South Georgia Island in Fishing Season.

[21] Whitehouse, M. J., Meredith, M. P., Rothery, P., 
Atkinson, A., Ward, P., and Korb, R. E. 2008. "Rapid Warming of the Ocean around South Georgia, Southern Ocean, during the 20th Centuary: Forcing, Characteristics and Implications for Lower Trophic Levels." Deep Sea Research 55 (1): 1218-1228.

[22] CCAMLR. 2011. "Limits on the Fishery for Champsocephalus gunnari in Statistical Subarea 48.3 in the 2011/12 Season." Accessed January 31, 2011. http://www.ccamlr.org/sites/drupal.ccamlr.org/files//42-0 1.pdf.

[23] CCAMLR. 2012. "Catch and Effort Data." Statistical Bulletin 24: 23-237.

[24] Sosinski, J., and Szlakowski, J. 1992. "Biological Characteristics and Biomass Estimates of the Fish Stocks on the South Georgia Shelf in the 1986/87-1988/89 Seasons." Acta Icthyologica et Piscatoria 22: 77-105.

[25] Brown, J., Brickle, P., Belchier, M., and Collins, M. 2010. "The Patagonian Toothfish: Biology, Ecology and Fishery." Advances in Marine Biology 58: 227-300.

[26] Roberts, J., Xavier, J. C., and Agnew, D. J. 2011. "The Diet of Toothfish Species Dissostichus Eleginoides and Dissostichus Mawsoni with Overlapping Distributions." Journal of Fish Biology 79: 138-154.

[27] CCAMLR. 2012. "Seabed Areas Used in Fishery Assessments." Statistical Bulletin 24: 267-269.

[28] North, A. W. 1991. Review of the Early Life History of Antarctic Notothenioid Fish. Berlin-Heidelberg: Springer-Verlag.

[29] Traczyk, R. J. "The Occurrence of Krill Euphausia Superba in the Floating Ice Edge Zone and Some Its Biological Data." Accessed June 15, 2011. http://georgianka.strefa.pl/krill_oc.html/http://georgianka. strefa.pl/index.html.

[30] Radtke, R. L., and Hourlgan, T. F. 1990. "Age and Growth of the Antarctic Fish Nototheniops Nudifrons." Fishery Bulletin 88 (3): 557-571.

[31] Greely, T. M., Gartner Jr, J. V., and Torres, J. J. 1999. "Age and Growth of Electrona Antarctica (Pisces: Myctophidae), the Dominant Mesopelagic Fish of the Southern Ocean.” Marine Biology 133: 145-158.

[32] La Mesa, M., and Vacchi, M. 2001. "Age and Growth of High Antarctic Notothenioid Fish.” Antarcfic Science 13 (3): 227-235.

[33] Sutton, C. P., and Horn, P. L. 2011. "A Preliminary Assessment of Age and Growth of Antarctic Silverfish (Pleuragramma antarcticum) in the Ross Sea, Antarctica." CCAMLR Science 18: 75-86.

[34] Linkowski, T. B., and Żukowski, C. 1980. "Observation on the Growth of Notothenia Coriiceps Neglecta Nybelin and Notothenia Rossi Marmorata Fischer in Admiralty Bay (King George Island, South Shetland Islands).”
Polish Polar Research 1 (2-3): 155-162.

[35] Traczyk, R. J. 2015. "Age, Growth and Distribution of the Antarctic Fish Chaenocephalus aceratus Based on Otoliths." Journal of Environmental of Science and Engineering A 4 (8): 401-419.

[36] La Mesa, M., Ashford, J., Larson, E., and Vacchi, M. 2004. "Age and growth of Scotia Sea Icefish, Chaenocephalus aceratus, from the South Shetland Islands." Antarctic Science 16 (3): 253-262.

[37] La Mesa, M., De Felice, A., Jones, C. D., and Kock, K. H. 2009. "Age and Growth of Spiny Icefish (Chaenodraco Wilsoni Regan, 1914) off Joinville-D’Urville Islands (Antarctic Peninsula)." CCAMLR Science 16: 115-130.

[38] Burchett, M. S. 1984. "The Life Cycle of Notothenia rossii from South Georgia." Bulletin British Antarctic Survey 61: 71-73.

[39] Burchett, M. S. 1983. "Age and Growth of the Antarctic Fish Notothenia rossii from South Georgia." British Antarctic Survey Bulletin 60: 45-61.

[40] Traczyk, R. J. 1989. "Analysis of the Microincrements and Otolith Morphologic of Pseudochaenichthys georgianus NORMAN, 1939 (SGI) from South Georgia (Antarctica) for Determination the Age, Growth and Important Periods of Fish Development." Accessed July 10, 2011. http://georgianka.strefa.pl/analipse.html.

[41] Traczyk, R. J. 1990. "Analysis of the Microincrements Rhythmic Structures in Otolith And Otolith Morphometry for the Age, Growth and Important Life Periods Determination of the Antarctic Fish Pseudochaenichthys georgianus." Accessed July 10, 2011. http://georgianka.strefa.pl/pseudoch.html.

[42] Belchier, M., Mitchell, R., Hanchet, S., Sharp, B., Leslie, R., and Parker, S. 2011. "Harvested Species." In Two-Thirtieth Meeting of the Scientific Committee, 343-364.

[43] CCAMLR. 2015. "Catch and Effort Data from Fisheries in CCAMLR's Convention Area." Statistical Bulletin 27: 2-12.

[44] Militelli, M. I., Macchi, G. J., and Rodrigues, K. A. 2015. "Maturity and Fecundity of Champsocephalus gunnari, Chaenocephalus aceratus and Pseudochaenichthys georgianus in South Georgia and Shag Rocks Islands." Polar Science 9: 258-266.

[45] Chojnacki, J., and Palczewski, P. 1981. "Age and growth of Pseudochaenichthys georgianus Norman 1937 (Family Chaenichthyidae) of the South Georgia Region." Polish Polar Research 2 (3-4): 145-157.

[46] Bronmark, C., Brodersen, J., Chapman, B., Hansson, L., Hulthen, K., and Nilsson, P. A. et al. 2015. "Costs and Benefits of Seasonal Migration in Cyprinid Fish." In $X V$ European Congress of Ichthyology, 1-190. 
[47] Witek, Z., Kalinowski, J., and Grelowski, A. 1988. "Formation of Antarctic Krill Concentrations in Relation to Hydrodynamic Processes and Social Behaviour." In Antarctic Ocean and Resources Variability, 237-245.

[48] Harmon, K. 2009. "Shrimpy Sea Life May Mix Oceans as Much as Tides and Winds Do." Accessed August 29, 2009.

http://www.scientificamerican.com/article.cfm?id=bio-oc ean-mixing.

[49] Pyper, W. 2008. "Krill Mix up the Ocean.” Accessed December 4, 2008. http://www.antarctica.gov.au/magazine/2006-2010/issue15-2008/science/krill-mix-up-the-ocean.

[50] CCAMLR. 1990. "By-Catch of Fish Larvae and Juvenile Fish.” In The Ninth Meeting of the Scientific Committee 9: 153-156.

[51] Ghigliotti, L., Ferrando, S., Carlig, E., Di Blasi, D., Gallus, L., and Pisano, E. et al. 2015. "Skip Spawning as a Reproductive Strategy in Antarctic Fish Species: The Antarctic Silverfish (Pleurogramma antarctica) Case Study." In XV European Congress of Ichthyology, 69-70.

[52] Anon. 1988. "Scientific Seminar on Antarctic Ocean Variability and Its Influence on Marine Living Resources, Paricularly Krill." In Antarctic Ocean and Resources Variability, 1-302.

[53] Walker, O. S., and Comiso, J. C. 2008. "The Influence of Sea Ice on Primary Production in the Southern Ocean: A Satellite Perspective in "Large Scale Characteristics of the Sea Ice Cover from AMSR-E and Other Satellite Sensor." Journal of Geophysical Research 113 (C5): 1-19.

[54] Greenpeace. 2008. "Do You Know What You Eat, Red List, Greenpeace, Sea Species." Accessed September 5, 2008.

http://www.greenpeace.org/international/en/campaigns/oc eans/which-fish-can-I-eat/red-list-of-species/.

[55] EDF Seafood Selector. 2012. "List of Seafood Health Alerts." Accessed November 1, 2012. http://seafood.edf.org/seafood-health-alerts.

[56] NRDC. 2014. "Mercury Contamination in Fish." Accessed January 28. http://www.nrdc.org/health/effects/mercury/guide.asp.

[57] US FDA. 2014. "Mercury Levels in Commercial Fish and Shellfish.” Accessed August 10, 2014. http://www.fda.gov/Food/FoodborneIllnessContaminants/ Metals/ucm115644.htm.

[58] Hall, R. A., Zook, E. G., and Meaburn, G. M. 1978. National Marine Fisheries Service Survey of Trace Elements in the Fishery Resources. NOAA Technical report.

[59] EFSA Panel on Contaminants in the Food Chain. 2012.
"Scientific Opinion on the Risk for Public Health Related to the Presence of Mercury and Methylmercury in Food." EFSA Journal 10 (12): 1-241.

[60] Ewing, B. 2008. "Environmental Pollutant Has Sex-Skewing Effect.” Accessed July 15, 2008. http://www.digitaljournal.com/article/257461.

[61] Washington State University. 2013. "Jet Fuel, Plastics Exposures Cause Disease in Later Generations; Reproductive Diseases, Obesity." Accessed January 24, 2013.

http//www.sciencedaily.com/releases/2013/01/130124183 630.htm.

[62] Karimi, R., Fitzgerald, T. P., and Fisher, N. S. 2014. “A Quantitative Synthesis of Mercury in Commercial Seafood and Implications-Database." Accessed August 21 ,

http://www.consumerreports.org/cro/news/2014/08/how-t o-reduce-your-mercury-exposure-from-seafood/index.ht $\mathrm{m}$.

[63] Suzuki, D. 2013. "Fukushima Radiation: Is it Safe to Eat the Fish?" Accessed October 9, 2013. http://ecowatch.com/2013/10/09/fukushima-radiation-saf e-to-eat-fish/.

[64] Navarrete, J. M., Zuniga, M. A., Espinosa, G., and Golzarri, J. I. 2015. "Radioactive Contamination Factor at Global Scale, through Marine Sediments Detection." In BIT's 4th Annual World Congress of Ocean, 34-35.

[65] Arias, J. E. 2015. "Algae: The Obvious Alternative to Fish Oils as a Feed Ingrediens." In BIT's 5th Annual World Congress of Ocean, 210-211.

[66] Broad, W. J. 1993. "Russians Describe Extensive Dumping of Nuclear Waste.” Accessed April 27, 1993. http://www.nytimes.com/1993/04/27/science/russians-des cribe-extensive-dumping-of-nuclear-waste.html?pagewan ted $=$ all.

[67] Madslien, J. 2006. "Nuclear Waste Poses Arctic Threat." Accessed October 19, 2006. http://news.bbc.co.uk/2/hi/europe/6058302.stm.

[68] Greenpeace. 1998. "Ocean Dumping History References Chronology of Developments Concerning the Dumping of Radioactive Wastes at Sea by the USSR/Russian Navy and Merchant Marine and the Loss of Nuclear-Powered Vessels ar Sea, 1975-1993." Accessed May 28, 1998. https://groups.yahoo.com/neo/groups/nukenet/conversatio ns/messages/1511.

[69] Lee, R. J. 1997. "TED Case Studies, Arctic Sea Dumping, Russian Toxic Dumping in the Arctic Sea." Accessed November 1, 1997. http://www1.american.edu/ted/arctic.htm.

[70] Nilsen, T. 2012. "Planning for New Expeditions to Arctic Nuclear Dustbin." Accessed September 26, 2012. 
http://barentsobserver.com/en/nature/planning-new-exped itions-arctic-nuclear-dustbin-26-09.

[71] Nilsen, T. 2012. "Time to Lift Dumped Submarine." Accessed $\quad$ August 2012. http://barentsobserver.com/en/nature/time-lift-dumped-su bmarine-28-08.

[72] Traczyk, R. J. 2009. Report on Length and Age of Haddock (Melanogrammus aegelfinus) Caught by the Fishing Ship Polonus in the Barents Sea, in Summer 2009. Research report.

[73] Losy, Z. 2012. "UK-Record Air Pollution, Ended Scale." Accessed April 10, 2012. http://translate.google.com/translate?client=tmpg\&hl=en \&langpair $=\mathrm{pl} \mid \mathrm{en} \& \mathrm{u}=\mathrm{http} \% 3 \mathrm{~A} / /$ losyziemi.pl/uk-rekordow o-zanieczyszczone-powietrze-skonczyla-sie-skala.

[74] NIMD. 2015. "Frequently Asked Questions-Minamata Disease Q \& A.” Accessed July 4, 2015. http://www.nimd.go.jp/archives/english/tenji/e_corner/eto p.html.

[75] NIMD. 2010. Ministry of the Environment, National Institute for Minamata Disease. NIMD Annual report.

[76] Fukushima Diary. 2016. "Sea Contamination." Accessed February 7, 2016. http://fukushima-diary.com/ecology-2/sea-contaminationecology/.

[77] Medonet. 2016. "Air Pollution Affects the Increase in the Number of Suicides." Accessed March 18, 2016. http://www.medonet.pl/zdrowie/wiadomosci/zanieczyszc zenie-powietrza-wplywa-na-wzrost-liczby-samobojstw,ar tykul,1619720.html.

[78] Boszke, L., Siepak, J., and Falandysz, J. 2003. "Total Mercury Contamination of Selected Organisms in Puck Bay, Baltic Sea, Poland." Polish Journal of Environmental Studies 12 (3): 275-285.

[79] Kwaśniak, J. 2012. “Organ Distribution, Accumulation and Detoxification of Mercury in Fish Caught in the Southern Baltic." Ph.D. thesis, University of Gdansk.

[80] HELCOM. 2010. "Hazardous substances in the Baltic Sea.” In Baltic Sea Environment Proceedings, 116.

[81] Greenpeace. 2014. "Pollution and Sea-Water and Oill." Accessed October 18, 2014. http://www.greenpeace.org/international/en/campaigns/oc eans/fit-for-the-future/pollution/.

[82] Lecterro. 2013. "EU Farmers Pollute the Baltic Sea." Accessed January 18, 2013. http://zmianynaziemi. $\mathrm{pl} /$ wideo/farmerzy-ue-zatruwaja-baltyk.

[83] Skerfving, S. 1995. "Exposure to Pollutants through Consumption of Contaminated Fish." Scandinavian Journal of Work, Environment \& Health 21 (2): 81-83.

[84] JAGR. 2012. "The Number of Paid Medical Visits is Increasing." Accessed October 12, 2012. http:/www.tvp.info/8783686/biznes/wzrasta-liczba-platn ych-wizyt-lekarskich/.

[85] Domagała, K. 2014. "Acute Shortage of Doctors in Germany." Accessed July 5, 2014. http://www.dw.com/pl/dotkliwy-brak-lekarzy-w-niemcze ch-b\%C4\%99dzie-jeszcze-gorzej/a-17760356.

[86] Mrozinska-Gogol, J. 2015. "Review Dissertation of Nadolna-Altyn, K. "Host-Parasite Interactions as Indicators in Biomonitoring of Baltic Sea Environment"." Review Ph.D. thesis, University of Gdańsk.

[87] Panel on Dietetic Products, Nutrition and Allergies of the European Commission. 2009. "Safety of "Lipid Extract from Euphausia Superba" as a Novel Food Ingredient." The EFSA Journal 938: 17.

[88] Kryczkowski, J. A., Jaeszke, A. M., and Proskura, E. 1977. "A Method Pretreatment of Sea Crayfish, Especially Crayfish Euphausia superba." Bulletin of the Patent Office (Biuletyn Urzędu Patentowego) 11 (91): 5-6.

[89] Penn, S., and Bevan, J. 2015. "Native Flora." Accessed March 23, 2015. http://www.sght.org/native-flora.

[90] Holman, R. T. 1998. "The Slow Discovery of the Importance of Omega 3 Essential Fatty Acids in Human Health." The Journal of Nutrition 128 (2): 4275-4335.

[91] Foubert, I. 2015. "Autotrophic Microalgae as an Alternative Source of Long Chain N-3 Polyunsaturated Fatty Acids: From Green Water to Health Conscious Consumer." In BIT's 4th Annual World Congress of Ocean 3: 266-267.

[92] Sen, B. 2015. "Nutritive and Economic Value of Algae." In BIT's 5th Annual World Congress of Ocean 3: 262-263.

[93] Olavur, G. 2015. "Open Ocean Macro Algae Cultivation Rig-in Situ in the North Atlantic Since 2010.” In BIT's 5th Annual World Congress of Ocean 2: 240-241.

[94] May, R. M., Beddington, J., Clark, C. W., Holt, S. J., and Laws, R. M. 1979. "Management of Multispecies Fisheries." Science 205: 267-277.

[95] Rosenberg, A. A., and Beddington, J. R. 1987. "Hervesting Interacting Species of Different Lifespans." Oxford Journals of Science \& Mathematical Medicine \& Biology 4 (3): 265-278.

[96] IWC. 2012. International Whaling Commission. Annual Reports of the International Whaling Commission 1970-2013.

[97] Masaaki, I. 2015. "Whaling Statistics." Accessed September 5, 2015. http://luna.pos.to/whale/sta.html.

[98] ANON. 1988. The State of Fish Stocks and Krill in the Atlantic Sector of Antarctica in the Season 1987/1988, SFI. Research report.

[99] Furusawa, M. 2011. "Echo Integration Near the Seabed." 
Journal of Marine Science and Technology 19 (3): 259-266.

[100] Echoview Software. 2016. "About Biomass Estimation.” Accessed

February

23,

2016.

http://support.echoview.com/WebHelp/How_to/Estimate biomass/About_Biomass_Estimation.htm.

[101] Campana, S. 2015. "Natural Tags and Markers for
Tracking and Identifying Fish." In $X V$ European Congress of Ichtiology 39: 1-190.

[102] Żabrowski, M. 2000. "The Osteology and Ossification Variability of the Skull of Antarctic White-Blooded Fish Chaenodraco wilsoni Regan, 1914 (Channichthyidae, Notothenioidei)." Acta Ichthyologica et Piscatoria 30 (2): 111-126. 